\title{
Værdisætning af skadesomkostninger ved affaldsforbrænding
}

- en analyse af dioxiners skadelige effekter og et regneeksempel på disse effekters samfundsøkonomiske omkostninger

Udarbejdet af cand.scient.pol. Dorthe Bjerrum Jensen og cand.oecon. Niels Dengsøe, Danmarks Miljøundersøgelser

TemaNord 2004:518 


\section{Værdisætning af skadesomkostninger ved affaldsforbrænding}

- en analyse af dioxiners skadelige effekter og et regneeksempel på disse effekters samfundsøkonomiske omkostninger

TemaNord 2004:518

(C) Nordisk Ministerråd, København 2004

ISBN 92-893-1004-9

ISSN 0908-6692

Tryk: Ekspressen Tryk \& Kopicenter

Oplag: 240

Trykt på miljøvenligt papir som opfylder kravene i den nordiske miljøsvanemærkeordning. Sælges gennem Nordisk Ministerråds salgsagenter, se listen på sidste side. Der findes flere publikationer fra Nordisk Ministerråd og Nordisk Råd på www.norden.org/publikationer.

\author{
Nordisk Ministerråd \\ Store Strandstræde 18 \\ DK-1255 København K \\ Telefon $(+45) 33960200$ \\ Telefax (+45) 33960202
}

\author{
Nordisk Råd \\ Store Strandstræde 18 \\ DK-1255 København K \\ Telefon $(+45) 33960400$ \\ Telefax $(+45) 33111870$
}

\section{www.norden.org}

\section{Det nordiske miljøsamarbejde}

Miljøsamarbejdet skal bidrage til at forbedre miljøet og forebygge problemer i Norden og internationalt. Samarbejdet ledes af Embedsmandskomiteen for miljøspørgsmål (EK-M). Det omfatter fastsættelse af fælles mål i handlingsplaner, fælles projekter, informationsudveksling og indsatser som for eksempel gælder Østeuropa gennem Nordic Environmental Finance Corporation (NEFCO).

\section{Nordisk Ministerråd}

blev oprettet i 1971 som samarbejdsorgan mellem de nordiske landes regeringer. Ministerrådet fremlægger forslag til Nordisk Råds sessioner, viderefører rådets rekommandationer, rapporterer til Nordisk Råd om samarbejdets resultater og leder arbejdet inden for de forskellige emneområder. Samarbejdet koordineres af samarbejdsministrene, der er udpeget af det enkelte lands regering. Ministerrådet træder sammen i forskellige sammensætninger - afhængigt af hvilke spørgsmål, der skal behandles.

\section{Nordisk Råd}

blev oprettet i 1952 som et samarbejdsorgan mellem de folkevalgte forsamlinger og regeringer i Danmark, Island, Norge og Sverige. Finland indtrådte i 1955. Færøernes, Grønlands og Ålands delegationer indgår i henholdsvis Danmarks Riges og Finlands delegationer. Rådet består af 87 medlemmer. Nordisk Råd er initiativtagende og rådgivende og har kontrollerende opgaver i det nordiske samarbejde. Nordisk Råds organer er plenarforsamlingen, præsidiet og udvalgene. 


\section{Indholdsfortegnelse}

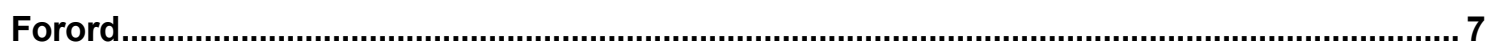

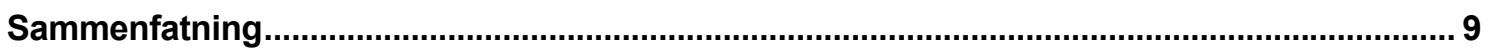

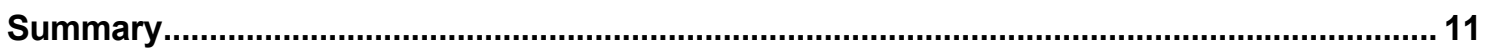

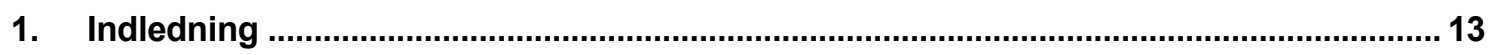

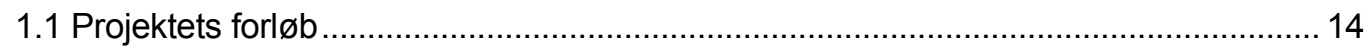

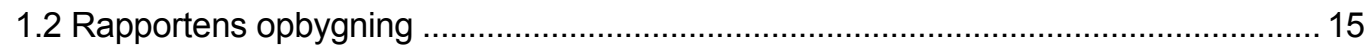

2. Samfundsøkonomisk analyse af

skadesomkostninger ved affaldsbehandling - introduktion ......................................... 17

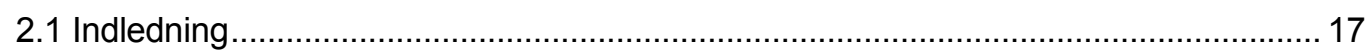

2.2 Norske undersøgelser af de samfunds$ø$ konomiske omkostninger ved affaldsbehandling .............................................. 18

2.3 Prissætning af sundhedsskader ved udledning af skadelige stoffer......................... 23

2.4 Samfundsomkostninger ved udledning af kemikalier fra affaldsforbrænding............ 23

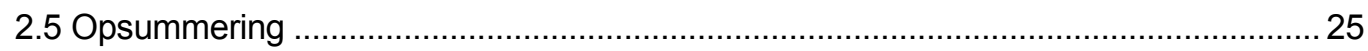

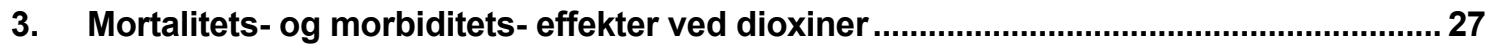

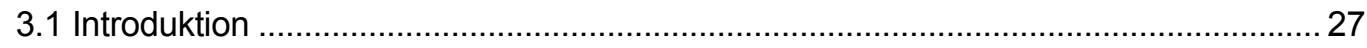

3.2 Mortalitetseffekter (dødelighed) ved dioxin ........................................................... 32

3.3 Morbiditetseffekter (sygdomme) ved dioxin ............................................................ 36

3.3.1 Gruppe I - relativt sikre effekter ................................................................... 39

3.3.2 Gruppe II - potentielle effekter ..................................................................... 40

3.3.3 Gruppe III - meget usikre effekter ............................................................. 41

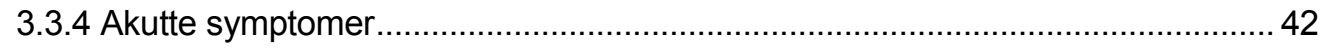

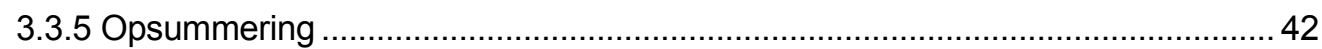

3.4 Usikkerheder ved undersøgelserne af dioxiners skadelige helbredseffekter............ 43

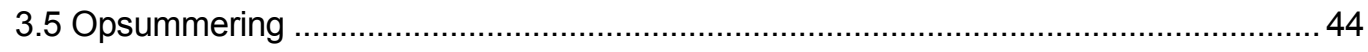

4. Regneeksempel: dioxin- relaterede helbredsomkostninger............................................ 47

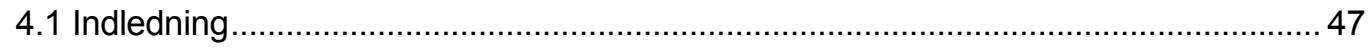

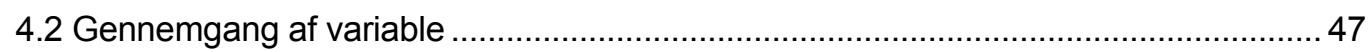

4.2.1 Danskernes årlige gennemsnitsindtag af dioxin fra fødevarer ......................... 47 
4.2.2 Andel af dioxin, der stammer fra dansk producerede fødevarer

4.2.3 Den årlige dioxinmængde, der tilføres

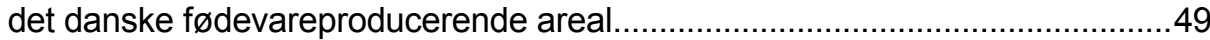

4.2.4 Andelen af danske emissioner, der ender på dansk territorium...........................50

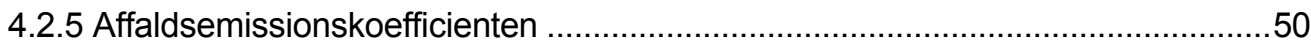

4.2.6 Dosis/respons-funktionen for kræftdødsfald .................................................52

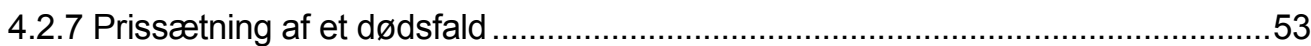

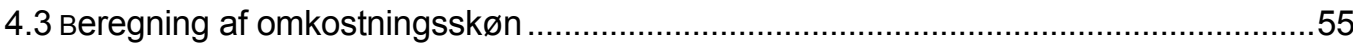

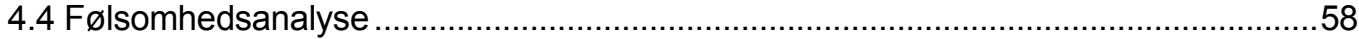

4.4.1 forskelle til de væsentligste referencer..........................................................61

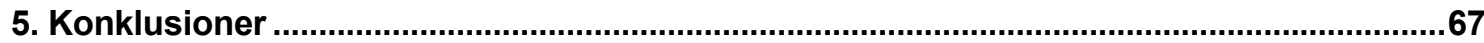

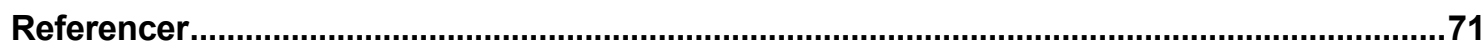




\section{Forord}

Denne rapport er udarbejdet ved Danmarks Miljøundersøgelser (DMU), Afdelingen for Systemanalyse, efter en samarbejdsaftale med Nordisk Ministerråds arbejdsgruppe for produkter og affald (PA-gruppen). Rapporten indeholder anden del af projektet om de nordiske slutbehandlingsafgifter på affald. Formålet med projektet har på den ene side været at vurdere resultaterne af eksisterende økonomiske værdisætningsundersøgelser af skadesomkostningerne ved affaldsbehandling og af evalueringer af slutbehandlingsafgifterne på affald i de nordiske lande. På den anden side har formålet været at udbygge den eksisterende viden vedrørende prissætning af de eksterne effekter af lavdosisemissioner fra affaldsforbrænding. Her er det valgt at fokusere specifikt på dioxinudledningen.

Rapporten er udarbejdet af cand.scient.pol. Dorthe Bjerrum Jensen og cand.oecon. Niels Dengsøe. Forskningsprofessor Mikael Skou Andersen har været projektleder og desuden bidraget med råd og vejledning. Rapportens forfattere påtager sig det faglige og indholdsmæssige ansvar for den endelige udformning af rapporten. Nordisk Ministerråd og repræsentanter i PA-gruppen kan således ikke tages til indtægt for rapportens betragtninger og konklusioner.

Undervejs i projektforløbet har en række personer bidraget med information, vurderinger og gode råd, hvorfor vi gerne vil benytte lejligheden for at sige tak. Det drejer sig om:

Søren Riff Alexandersen, Kort \& Matrikelstyrelsen

Rodan Bruce, Environmental Protection Agency, USA

Niels Ahlgren, Uno-consult, Sverige

Christian Fischer, Miljøstyrelsen

Ole Gravgaard, Danmarks Statistik

John Christian Larsen, Toksikologisk Institut, Fødevaredirektoratet

Charlotte Libak Hansen, COWI A/S

Erik Hansen, COWI A/S

Eva Bonefeld-Jørgensen, Institut for Miljø og Arbejdsmedicin, Aarhus Universitet

Poul Bo Larsen, Miljøstyrelsen

Flemming Møller, Danmarks Miljøundersøgelser

Helle Petersen, Miljøstyrelsen

Marianne Thomsen, Danmarks Miljøundersøgelser

Jørgen Vikelsøe, Danmarks Miljøundersøgelser

Roskilde, december 2003 


\section{Sammenfatning}

Selvom fire af de nordiske lande - Danmark, Finland, Norge og Sverige - har valgt at indføre en afgift på behandlingen af affald, viste rapporten Vurdering af de nordiske slutbehandlingsafgifter på affald - økonomisk vardiscetning og evaluering (Dengsøe, 2001), at vidensgrundlaget for at fastsætte en sådan afgift på det samfundsøkonomisk mest optimale niveau endnu er meget sparsomt. Der findes således kun et relativt begrænset antal undersøgelser af de samfundsøkonomiske omkostninger ved de helbreds- og miljømæssige skadesvirkninger af forskellige affaldsbehandlingsmetoder. Problemet er bl.a., at det naturvidenskabelige grundlag vedrørende f.eks. emissionsstørrelser og helbredseffekter endnu er meget usikkert.

I de nordiske lande er forbrænding en af de væsentligste affaldsbehandlingsmetoder. Problemet med affaldsforbrænding er, at der udledes en mængde stoffer, som kan være skadelige for mennesker og miljø. De europæiske ExternE-studier har fastlagt værdier og skøn for skadesomkostningerne ved en række af disse udledninger, såsom $\mathrm{SO}_{2}, \mathrm{NO}_{\mathrm{X}}$ og $\mathrm{CO}_{2}$ (Holland et al., 1999). Det er imidlertid blevet påpeget, at disse emissionstyper ikke giver anledning til de væsentligste samfundsøkonomiske omkostninger ved affaldsforbrænding. Det gør i stedet en række miljø- og sundhedsskadelige kemikalier, som f.eks. krom og mangan samt dioxiner, der ifølge en af de seneste norske undersøgelser udgør $85-95 \%$ af de samlede skadesomkostninger ved affaldsforbrænding (ECON, 2000: 81). ${ }^{1}$

Tabel 1: Gennemsnitligt dagligt indtag af dioxin ${ }^{2}$

\begin{tabular}{|l|l|l|}
\hline & $\begin{array}{l}\text { Indtag (picogram /kg. krops- } \\
\text { vægt/dag), } \\
\text { TEQ (inkl. PCB) }\end{array}$ & Reference \\
\hline $\begin{array}{l}\text { WHO- } \\
\text { anbefa- } \\
\text { ling }\end{array}$ & $1-4$ & WHO, 1999 \\
\hline Danmark & 1,7 & $\begin{array}{l}\text { Fødevaredirektoratet \& Plantedirektora- } \\
\text { tet, 2001 }\end{array}$ \\
\hline Norge & $2,3-3,2^{*}$ & Cederberg, Larsen \& Ovesen, 1999 \\
\hline Sverige & $4,1-4,8^{*}$ & Cederberg, Larsen \& Ovesen, 1999 \\
\hline
\end{tabular}

Kilde: Fødevaredirektoratet \& Plantedirektoratet, 2001:23ff.; Cederberg, Larsen \& Ovesen, 1999; WHO, 1999:21

* Da undersøgelserne er fra før 1998, kan toksicitetsopgørelserne muligvis være anderledes end WHO-opgørelsen og den danske (se boks 2).

\footnotetext{
${ }^{1}$ Disse beregninger er baseret på eksisterende anlæg, der ikke nødvendigvis lever op til kravene i det nye affaldsdirektiv.

${ }^{2}$ Der antages i hovedreglen en person på ca. $70 \mathrm{~kg}$.
} 
I dette studie er dioxiner valgt som analyseobjekt, fordi indtaget af disse stoffer sandsynligvis befinder sig i den høje ende eller overskrider det tolerable daglige indtag, som blev anbefalet af WHO i 1998, jf. tabel 1 (WHO, 1999).

Når mennesker indtager dioxin - hvilket primært sker via føden - kan det selv i meget små mængder give anledning til alvorlige helbredseffekter, såsom hudsygdomme, problemer med leveren samt kræftsygdomme og -dødsfald. Selvom forskerne har kendskab til en række af sådanne effekter, findes der endnu stort set ingen kvantificeringer af sammenhængen mellem eksponering og effekt i form af dosis/respons-modeller. Disse effekter er helt afgørende for at kunne fastlægge et skøn over de samfundsøkonomiske omkostninger af dioxinudledningen ved affaldsforbrænding.

Den amerikanske miljøstyrelse udsendte i 2000 en foreløbig afrapportering fra et meget omfattende projekt vedrørende vurdering af dioxiner (US-EPA, 2000). I denne rapport opstilles en dosis/respons-model for sammenhængen mellem dioxinindtag og kræftdødsfald. Med baggrund i denne model samt danske data for udledning og indtag opstiller nærværende rapport et regneeksempel på de samfundsøkonomiske omkostninger ved dioxinudledning fra affaldsforbrænding i Danmark, og det vurderes, at disse ligger på omkring 13 DKK pr. ton (med et usikkerhedsinterval på 1-128 DKK/ton). Dette tyder på, at dioxiner måske alligevel ikke er en af de væsentligste emissionstyper samfundsøkonomisk set. Selvom det er en meget farlig gruppe af stoffer, udledes der så begrænsede mængder (6,4 - 28,9 g pr. år), at skaderne er forholdsvis små.

Pga. de mange usikkerheder ved beregningen må skønnet på 13 DKK pr. ton dog som nævnt betragtes som et regneeksempel snarere end som en eksakt beregningspris, der kan anvendes direkte i f.eks. økonomiske værdisætningsundersøgelser eller cost/benefitanalyser. Et af de væsentligste problemer ved dette skøn er, at den anvendte dosis/respons-model fastsætter risikoen meget højt. Til gengæld er der hverken inkluderet andre helbredsskader end kræft eller skader på miljøet. Det er således heller ikke muligt at vurdere, om de 13 DKK er udtryk for et lavt eller højt skøn.

Konklusionen er derfor, at der er behov for mere viden på området, før det er muligt at fastsætte et mere praktisk anvendeligt skøn for skadesomkostningerne ved dioxin. En fremtidig undersøgelse af skadesomkostningerne bør endvidere omfatte skaderne ved udledning af krom og mangan, idet disse stoffer tilsyneladende giver anledning til større skader end dioxiner. Dette skyldes bl.a., at de nævnte stoffer i forbindelse med forbrænding af affald udledes i meget større mængder end dioxiner. 


\section{Summary}

The background of this report is the conclusion of the former report of this project (Dengsøe, 2001). That report stated that even though four of the Nordic countries - Denmark, Finland, Norway and Sweden - have implemented a tax on disposal of waste, we are still in need of more information in order to fix such a tax on the socioeconomically most optimal level. There are only relatively few studies of the socioeconomic costs of the different methods of waste disposal. One of the problems is the uncertainty of the scientific knowledge of for instance the size of emissions and the dose-response models of different chemical substances.

In the Nordic countries waste incineration is one of the main methods for waste disposal. The problem is that waste incineration involves emissions of a number of substances, which can be harmful to humans and the environment. The European ExternE studies have estimated the damage costs of several of these emissions such as $\mathrm{SO}_{2}, \mathrm{NO}_{\mathrm{X}}$ and $\mathrm{CO}_{2}$ (Holland et al., 1999). Nevertheless, it has been pointed out that these emissions do not cause the largest part of the socioeconomic costs of waste incineration. According to a new Norwegian study, substances such as chromium, manganese and dioxins make up $85-95 \%$ of the total socioeconomic costs of waste incineration (ECON, 2000:81). ${ }^{3}$

Table 1: Average daily intake of dioxins ${ }^{4}$

\begin{tabular}{|l|l|l|}
\hline & $\begin{array}{l}\text { Intake (picogram } / \mathrm{kg} \text {. body } \\
\text { weight/day), } \\
\text { TEQ (incl. PCB) }\end{array}$ & Reference \\
\hline $\begin{array}{l}\text { WHO: Toler- } \\
\text { able daily in- } \\
\text { take }\end{array}$ & $1-4$ & WHO, 1999 \\
\hline Denmark & 1,7 & $\begin{array}{l}\text { Fødevaredirektoratet \& Plante- } \\
\text { direktoratet, 2001 }\end{array}$ \\
\hline Norway & $2,3-3,2 *$ & $\begin{array}{l}\text { Cederberg, Larsen \& Ovesen, } \\
1999\end{array}$ \\
\hline Sweden & $4,1-4,8^{*}$ & $\begin{array}{l}\text { Cederberg, Larsen \& Ovesen, } \\
1999\end{array}$ \\
\hline
\end{tabular}

Reference: Fødevaredirektoratet \& Plantedirektoratet, 2001:23ff.; Cederberg, Larsen \& Ovesen, 1999; WHO, 1999

* Since the studies are earlier than 1998, the toxicity figures may be different from the figures by WHO and Denmark.

\footnotetext{
${ }^{3}$ These calculations are based on existing plants that do not necessarily fulfil the requirements in the new waste directive.

${ }^{4}$ In general, the assumption is based on a person of $70 \mathrm{~kg}$.
} 
Dioxins were chosen as objects of this study, because the intake of these substances probably is in the high end or exceed the tolerable daily intake recommended by WHO (WHO, 1999).

The human intake of dioxins can - even in very small doses - cause serious health damages, such as skin diseases, problems with the liver and different kinds of cancer. Although the researchers know of these problems, the dose-response models are few and uncertain. These dose-response models are vital for the estimation of the socioeconomic costs of the dioxin emissions from waste incineration.

The American Environmental Protection Agency put out a draft version of a report from a very thorough dioxin study in 2000 (US-EPA, 2000). This study includes a dose-response model of the relationship between dioxin and cancer mortality. This model and Danish emission and intake data are used in the present report to estimate the socioeconomic costs of dioxin emission from waste incineration in Denmark and it is estimated that these costs are about $13 \mathrm{DKK}$ pr. ton of waste (the uncertainty range is $1-128 \mathrm{DKK} /$ ton). This indicates that dioxin may not be one of the most important kinds of emission from a socioeconomic point of view. Even though dioxins can cause major health problems, the emissions are so limited $(6,4-28,9 \mathrm{~g}$ pr. year) that the economic damages are probably relatively small.

Considering the large number of uncertainties, the estimate of 13 DKK pr. ton has to be looked upon as an example of calculation rather than an exact price that can be used directly in economic valuation studies or cost/benefit analyses. One of the major problems of this estimate is that the dose-response model ascribes a very high risk to dioxins. On the other hand, the estimate excludes all morbidity effects and potential damages on the environment. Consequently, it is not possible to asses whether $13 \mathrm{DKK}$ pr. ton is a high or a low estimate.

The conclusion is that more information about dioxins is necessary to estimate the socioeconomic costs of dioxin emission from waste incineration. A future study of the damage costs should also include the damages from chromium and manganese since these substances seem to cause larger damage than dioxins. The reason (among others) is that these substances are emitted in much larger amounts than dioxins. 


\section{Indledning}

I Danmark blev der i 2000 produceret over 13 millioner tons affald, hvilket svarer til ca. 2,5 ton pr. indbygger (Miljøstyrelsen, 2001:7). ${ }^{5}$ Dette svarer nogenlunde til mængderne pr. indbygger i de øvrige nordiske lande, om end Danmark er en af de største affaldsproducenter (Fischer \& Crowe, 2000:28f). Behandlingen af affald er derfor en meget væsentlig samfundsopgave, og det er nødvendigt at overveje, hvilken kombination af behandlingsmetoder - såsom forbrænding, kompostering, genanvendelse og deponering - der ud fra en samfundsøkonomisk betragtning er at foretrække. Dette er kun muligt at vurdere, hvis der findes en tilstrækkeligt omfattende opgørelse over samtlige samfundsøkonomiske omkostninger og fordele ved de forskellige metoder.

Samtidig er det kun muligt at nå den samfundsøkonomisk mest optimale sammensætning af affaldsbehandlingsformerne, hvis de aktører, der efterspørger affaldsbehandlingen (herunder forbrugerne), skal betale den reelle pris for denne affaldsbehandling. Den "reelle" pris omfatter ikke alene de direkte omkostninger, men også de såkaldte eksternalitetsomkostninger, der ikke er inkluderet i den markedsbestemte pris på affaldsbehandling. ${ }^{6}$ Det drejer sig f.eks. om de samfundsomkostninger, der er et resultat af, at udledninger fra affaldsbehandlingen skader miljøet og det menneskelige helbred. Disse samfundsomkostninger kan integreres i behandlingsprisen ved at pålægge denne en afgift. Da affaldsforbrænding er en forholdsvis udbredt behandlingsmetode af "kommunalt affald" i flere af de nordiske lande, er fokus for denne rapport således de samfundsøkonomiske eksternalitetsomkostninger ved affaldsforbrænding.

Projektet er en fortsættelse af det i 2000-2001 gennemførte "Vurdering af de nordiske slutbehandlingsafgifter på affald - økonomisk voerdisœetning og evaluering" (Dengsøe, 2001). Også dette projekt blev gennemført under PA-gruppen (Produkt- og Affaldsgruppen) i Nordisk Ministerråd og omhandlede slutbehandlingsafgifterne på affald i de nordiske lande. I dette projekt blev det bl.a. noteret, at der var stor forskel på størrelsen af disse afgifter mellem de nordiske lande. Formodningen var, at dette på længere sigt ikke kunne udelukkes at ville medføre en forøget eksport og import af affald mellem landene. Denne aktivitet ville ikke være begrundet $\mathrm{i}$ komparative fordele $\mathrm{i}$ affaldsbehandling men snarere $\mathrm{i}$ forskellen på afgiftsbelastningen. Endvidere viste rapporten, at der hersker en generel usikkerhed om det optimale niveau for affaldsbeskatning i de nordiske lande, idet fastlæggelsen af slutbehandlingsafgifter generelt ikke er baseret på forsøg på prissætning af de eksterne effekter ved affaldsbortskaffelse. For en række effekter kan der i litteraturen hentes skøn for effekterne til brug for prissætning, men når det gælder effekterne af affaldsforbrænding, findes der kun få undersøgelser, der kan danne basis for prissætning.

\footnotetext{
${ }^{5}$ Med et befolkningstal på ca. 5,3 mio. mennesker i Danmark. Ses alene på husholdningsaffaldet produceredes der ca. 0,6 ton pr. indbygger

${ }^{6}$ Dette forklares grundigere i kapitel 2.
} 
Det første formål med dette projekt er dermed at opgøre det nordiske og internationale vidensgrundlag om prissætning af miljø- og sundhedseffekterne ved affaldsbehandling med henblik på at vurdere niveauet for slutbehandlingsafgifterne på affald i de nordiske lande.

De europæiske ExternE-studier har fastlagt værdier for konventionelle luftforureninger $\left(\mathrm{SO}_{2}, \mathrm{NO}_{\mathrm{X}}\right)$ samt givet skøn for klimagasser, såsom $\mathrm{CO}_{2}$ og metan (Holland et al., 1999). ${ }^{7}$ Disse emissionstyper ser imidlertid ikke ud til at være skyld i de væsentligste samfundsøkonomiske omkostninger ved affaldsforbrænding. Det norske Senter for Økonomisk Analyse (ECON) har således beregnet, at en markant del af samfundsomkostningerne ved forbrændingen udgøres af kemikalier, såsom krom, mangan, bly og nikkel samt af den yderst giftige gruppe af dioxiner (ECON, 2000, 2001). Som nævnt i forstudiet til denne rapport (Dengsøe, 2001) er denne gruppe imidlertid ikke så omfattende analyseret. Det er derfor ikke muligt at foretage en fuldstændig cost/benefit-vurdering og deraf følgende prioritering mellem forskellige affaldsbehandlingsmetoder, før informationsgrundlaget om sidstnævnte stoffer er blevet forbedret. Af den grund er det i dette projekt valgt at fokusere på dioxinerne, der selv i ekstremt små doser er meget farlige for det menneskelige helbred.

Det andet formål med dette projekt er at udbygge den eksisterende viden vedrørende prissætning af de eksterne effekter af lavdosisemissioner fra affaldsforbrænding. Dette indsnævres til en analyse af de samfundsøkonomiske omkostninger ved dioxinudledningen i forbindelse med affaldsforbrænding.

\subsection{Projektets forløb}

Første led i projektet var et omfattende studie af den nordiske og øvrige internationale litteratur på området. Formålet var primært at få et overblik over udledningsdata og data vedrørende de miljø- og helbredsmæssige effekter af dioxinerne, dvs. dosis/responsmodeller. Det viste sig dog relativt hurtigt, at dioxiner i sig selv vurderes at have en relativt begrænset effekt på miljøet. Fokus blev derfor rettet mod de helbredsmæssige effekter. Trods de mange studier af dioxinernes morbiditets- og mortalitetseffekter har et af problemerne i projektet imidlertid været at etablere specifikke dosis/respons-funktioner for sundhedseffekterne af dioxin, hvilket er en forudsætning for prissætningen. Parallelt med projektets bevilling offentliggjorde den amerikanske miljøstyrelse sin meget omfattende rapport vedrørende en revurdering af dioxineffekter (Draft Dioxine Reassessment). Oprindeligt var det meningen, at nærværende projekt selv skulle fremkomme med skøn for dosis/respons-funktioner på baggrund af konsultationer med eksperter på feltet. I stedet er det valgt at tage udgangspunkt i de amerikanske skøn - da EU hidtil har veget tilbage for at fremkomme med egentlige dosis/respons-funktioner - og at få disse vurderet og kvalificeret gennem dialog med diverse eksperter.

\footnotetext{
${ }^{7}$ EU-kommissionen har siden begyndelsen af 1990'erne været med til at finansiere et omfattende forskningsprojekt om eksternaliteter ved energifremstilling (Externalities om Energy, ExternE).
} 
Andet led i projektet var derfor at få en ekspertvurdering af de dioxindata, der var blevet indsamlet. Dette blev gjort ved at identificere ca. 25 internationale dioxin-eksperter, som modtog en henvendelse om at give deres vurdering af det eksisterende vidensgrundlag. Problemet var imidlertid, at disse adspurgte personer alle hver især er eksperter på meget afgrænsede dele af problemstillingen, hvorfor de ikke mente sig i stand til at besvare de relativt brede spørgsmål. Responsen på rundspørgen var derfor meget begrænset. I stedet har diverse eksperter været inddraget undervejs, idet de er blevet rådspurgt om specifikke emner, der har relevans for netop deres forskningsområde.

Trods ekspertinddragelsen har det vist sig sværere end først antaget at udarbejde en prissætning af dioxinernes effekt. Der har vist sig at være væsentlig usikkerhed mht. emissionsdata, spredning, dioxinernes vej i det økologiske kredsløb og ikke mindst opgørelsen af dosis/respons-funktioner. Omkostningsopgørelsen i kapitel 5 må derfor opfattes som et regneeksempel snarere end et præcist tal for de faktiske omkostninger. Beregningseksemplet illustrerer derved usikkerheden ved cost/benefit-opgørelser af miljø- og sundhedseffekter på affaldsområdet og dermed, at resultaterne af sådanne beregninger snarere må betragtes som pejlemærker end som eksakte værdier.

\subsection{Rapportens opbygning}

Nærværende rapport er bygget op som følger. I kapitel 2 gives en introduktion til, hvordan det er muligt at udarbejde en samfundsøkonomisk analyse af skadesomkostningerne (de negative eksternaliteter) ved affaldsbehandling, herunder affaldsforbrænding. I kapitlet gøres rede for forskellige prissætningsmetoder, hvorefter resultaterne fra de tidligere nævnte ECON-studier af affaldsbehandling fremlægges og diskuteres. Endelig argumenteres der for relevansen af at udvælge dioxiner til et nøjere studie.

I kapitel 3 gøres rede for den omfangsrige litteratur vedrørende dioxiners effekter på det menneskelige helbred. Der argumenteres dernæst for primært at tage udgangspunkt i en rapport fra EU-kommissionen samt et meget omfattende studie fra den amerikanske miljøstyrelse. På baggrund af disse og andre studier gøres herefter rede for de mange morbiditetseffekter, der formodes at være forbundet ved dioxineksponering. Endvidere diskuteres kræftrisikoen ved dioxin og de deraf følgende mortalitetseffekter ved stoffet. Endelig diskuteres den udbredte uenighed om vurderingen af dioxinernes effekter blandt eksperterne, samt hvordan dette spørgsmål håndteres i nærværende rapport.

Kapitel 4 indeholder et eksempel på at vurdere de samfundsøkonomiske omkostninger ved dioxinudledningen fra affaldsforbrænding. Dette gøres ved i en række led at koble data for udledning, antagelser vedrørende spredning af dioxin og optagelse via fødevarer, en amerikansk dosis/respons-model samt en vedtaget værdi for statistisk liv. Pga. de mange usikkerhedselementer i den lange kausalkæde kan der kun udregnes et meget usikkert skøn, der imidlertid kan give et generelt fingerpeg om niveauet for omkostningerne.

I kapitel 5 inddrages den tentative prissætning af dioxinerne fra kapitel $4 \mathrm{i}$ den vurdering af de nordiske slutbehandlingsafgifters udformning, der var et af formålene med analysen. Det diskuteres, hvilken betydning den reviderede prissætning af dioxiner får for slutbehandlingsafgifterne på affald, samt om der kunne være basis for en tilsvarende revurdering af omkostningerne ved andre af de stoffer, der udledes ved affaldsforbrænding. 


\section{Samfundsøkonomisk analyse af skadesomkostninger ved affaldsbehandling - introduktion}

\subsection{Indledning}

For at kunne foretage en samfundsøkonomisk analyse af affaldsbehandling er det nødvendigt at indsamle en lang række af informationer om de budget- og velfærdsøkonomiske gevinster og omkostninger ved de forskellige former for affaldsbehandling. I dette kapitel er de velfærdsøkonomiske effekter, der i den miljøøkonomiske litteratur omtales som "negative eksternaliteter", beskrevet nærmere. Eksternaliteterne ved udledningen af skadelige stoffer fra affaldsbehandling er de skadesomkostninger på miljø og sundhed, som uden kompensation påføres andre, og som der ikke umiddelbart findes noget marked for.

I de senere år er der sket betydelige fremskridt i udviklingen af metoder til at vurdere eksternaliteterne ved forskellige økonomiske aktiviteter. I Europa gælder dette især EUkommissionens forskningsprojekt om eksternaliteter ved energifremstilling ('Externalities of Energy' (ExternE)), der siden begyndelsen af 1990'erne har involveret over 50 forskerteams fra 15 forskellige lande. ${ }^{8}$

De hidtil gennemførte beregninger af skadesomkostningerne ved affaldsbehandling er forbundet med en betydelig usikkerhed, som følge af usikkerhed om de faktiske udledninger af skadelige stoffer ved affaldsbehandling og de anvendte beregningspriser, der i mangel af markedspriser er et udtryk for et samfunds indirekte prissætning af skaderne på miljø og sundhed ved udledning af stofferne.

En fremgangsmåde at tilvejebringe beregningspriser på er at gennemføre spørgeskemaundersøgelser af borgernes betalingsvillighed ('Willingness-To-Pay' (WTP)) for reduktioner i miljø- og sundhedsbelastningerne ved affaldsbehandling. WTP-metodens ulemper såsom usikkerhed og mangelfuld viden om affaldsbehandling er beskrevet nærmere i forbindelse med det gennemførte litteraturstudie af de eksisterende betalingsvillighedsundersøgelser vedrørende affald for Nordisk Ministerråd (Dengsøe, 2001). I dette kapitel er det beskrevet, hvordan beregningspriser for skadesomkostningerne ved udledningen af skadelige stoffer alternativt kan tilvejebringes ved hjælp af skadesfunktioner, renseomkostninger, nationale afgifter eller som den forventede internationale kvotepris i forbindelse med handlen med f.eks. $\mathrm{CO}_{2}$-udledninger. En sammenligning af de beregningspriser, som

\footnotetext{
${ }^{8}$ Eksternaliteterne ved forbrænding af affald er i ExternE-projektet beskrevet for affaldsforbrændingsanlæg i Frankrig, Italien og Spanien (http://externe.jrc.es/). Da affaldsforbrænding i Sydeuropa ofte ikke er direkte sammenlignelig med tilsvarende behandling i Norden, anvendes resultaterne af disse undersøgelser ikke i denne analyse.
} 
fremkommer i forbindelse med de forskellige fremgangsmåder, illustrerer imidlertid, hvor vanskeligt det er at generere et sæt af konsistente beregningspriser for udledningen af skadelige stoffer. Der er således behov for en betydelig forsknings- og udredningsindsats i de kommende år for at afklare dette.

For at reducere de forskellige usikkerheder, der er forbundet med beregningerne af eksternaliteterne ved affaldsbehandling, er det nødvendigt, at der foretages opdaterede opgørelser over de faktiske udledninger af de skadelige stoffer fra de eksisterende affaldsbehandlingsanlæg. Endvidere er det afgørende, at der findes videnskabeligt dokumenterede sammenhænge mellem udledningen af stofferne og effekterne af udledningerne på miljø og sundhed (dosis/respons). Som det fremgår af afsnit 4, er det især vigtigt at forbedre den eksisterende viden om udledningen af selv meget små mængder af udvalgte miljø- og sundhedsfarlige kemikalier fra affaldsforbrænding (ofte udtrykt ved tærskelværdier) som f.eks. dioxiner og tungmetallerne mangan $(\mathrm{Mn})$ og krom $(\mathrm{Cr})$. Endvidere er det vigtigt at vide noget om effekterne af disse mikroforureninger ('micropollutants') over tid (langtidseksponering).

I afsnit 2 gennemgås nogle omfattende undersøgelser af de samfundsøkonomiske skadesomkostninger ved affaldsbehandling, der er gennemført i Norge i de senere år. I afsnit 3 beskrives forskellige metoder til at beregne skadesomkostningerne på sundhed ved udledningen af skadelige stoffer. Især prissætningen af et statistisk liv kan have stor betydning for vurderingen af udledningen af de forskellige skadelige stoffer. I afsnit 4 er betydningen af at udelade de samfundsøkonomiske skadesomkostninger ved udledning af miljøog sundhedsfarlige kemikalier som dioxiner og tungmetaller ved affaldsbehandling beskrevet nærmere.

\subsection{Norske undersøgelser af de samfunds- økonomiske omkostninger ved affaldsbehandling}

Udledningerne fra affaldsbehandling består af udledningen af drivhusgasser, andre gasser $\left(\mathrm{NO}_{\mathrm{x}}, \mathrm{SO}_{2}, \mathrm{VOC}\right)^{9}$, partikler samt miljø- og sundhedsfarlige kemikalier, der omfatter dioxiner og tungmetaller. Som det fremgår af et internationalt litteraturstudie af samfundsøkonomiske analyser af gevinsterne ved genanvendelse for den danske Miljøstyrelse, omfatter de fleste undersøgelser imidlertid kun nogle af udledningerne (Dengsøe, 2002).

I de senere år er der gennemført nogle omfattende undersøgelser af de samfundsøkonomiske skadesomkostninger ved udledningerne fra affaldsbehandling i Norge (Vennemo, 1995; SFT, 1996; ECON, 1995; 1997; 2000 og 2001; Starring og Vennemo, 1997). Undersøgelserne er bl.a. blevet brugt til at vurdere skadesomkostningerne ved forbrænding, deponering eller kompostering af forskellige affaldsfraktioner (ECON, 2000) og til at vurdere mulighederne for at ændre udformningen af den eksisterende norske slutbehandlingsafgift på forbrænding af affald til en afgift på udledningerne ved affaldsforbrændingen (ECON, 2001).

\footnotetext{
${ }^{9}$ I ECON (2001: 18) omfatter "andre drivhusgasser” også HF og HCl. I ECON (2000: 70) indgår gasserne i miljø- og sundhedsfarlige kemikalier.
} 
Udover en viden om udledningerne af de skadelige stoffer fra affaldsbehandling er det nødvendigt, at der eksisterer nogle beregningspriser for skadesomkostningerne ved udledningerne af de forskellige stoffer for at kunne gennemføre en økonomisk værdisætning af skadesomkostningerne ved affaldsbehandling. I dette afsnit er de forskellige metoder til at tilvejebringe beregningspriser for skadesomkostningerne beskrevet med udgangspunkt i rapporten Miljøkostnader ved avfallsbehandling, der er udarbejdet for Miljøverndepartementet (ECON, 2000).

Tabel 2: Norske beregningspriser for skadesomkostningerne ved udledningen af skadelige stoffer ved affaldsbehandling

\begin{tabular}{|c|c|c|c|c|}
\hline \multirow{2}{*}{\multicolumn{2}{|c|}{ Metode }} & \multicolumn{3}{|c|}{$\begin{array}{l}\text { Beregningspriser } \\
\text { (NOK pr. udledt enhed) }\end{array}$} \\
\hline & & Lavt skøn & Bedste skøn ${ }^{10}$ & Højt skøn ${ }^{11}$ \\
\hline \multicolumn{5}{|c|}{ Drivhusgasser (ton) } \\
\hline $\mathrm{CO}_{2}$ & $\begin{array}{l}\text { Den forventede internationale } \\
\text { pris på } \mathrm{CO}_{2} \text {-kvoter }\end{array}$ & $70^{12}$ & 130 & 200 \\
\hline $\begin{array}{l}\text { Metan } \\
\left(\mathrm{CH}_{4}\right)\end{array}$ & $\begin{array}{l}21 \mathrm{x} \text { beregningsprisen for } \mathrm{CO}_{2} \\
\left(\mathrm{GWP}_{(\mathrm{CH} 4)}=21 \cdot \mathrm{GWP}_{(\mathrm{CO} 2)}\right)^{13}\end{array}$ & 1.470 & 2.730 & 4.20 \\
\hline \multicolumn{5}{|c|}{ Andre gasser (kg) } \\
\hline $\mathrm{SO}_{2}$ & $\begin{array}{l}\text { Sats for norsk svovlafgift på an- } \\
\text { vendelsen af mineralolie }\end{array}$ & \multicolumn{3}{|l|}{17} \\
\hline $\mathrm{NO}_{\mathrm{x}}$ & $\begin{array}{l}\text { Forventede tiltagsomkostninger } \\
\text { for at opfylde reduktionsmålsæt- } \\
\text { ning (SFT, 2000) }\end{array}$ & \multicolumn{3}{|l|}{15} \\
\hline VOC & $\begin{array}{l}\text { Højeste skøn for de forventede } \\
\text { tiltagsomkostninger for at opfyl- } \\
\text { de reduktionsmålsætning }\end{array}$ & \multicolumn{3}{|l|}{4} \\
\hline $\mathrm{HF}$ & Dosis/respons & \multicolumn{3}{|l|}{20.000} \\
\hline $\mathrm{HCl}$ & Dosis/respons & \multicolumn{3}{|l|}{100} \\
\hline \multicolumn{5}{|c|}{ Partikler (kg) } \\
\hline
\end{tabular}

\footnotetext{
${ }^{10}$ Værdien af statistisk liv $($ VSL $)=12$ mio. NOK.

${ }^{11}$ Værdien af statistisk liv (VSL) $=30$ mio. NOK.

12 "Som lavt alternativ benyttes anslag for skadekostnader fra Pearce et al. (1996), som antas å stige over tid" (ECON, 2000: 49).

${ }^{13}$ Global Warming Potential (GWP).
} 


\begin{tabular}{|l|l|l|l|l|}
\hline $\begin{array}{l}\text { Partik- } \\
\text { ler }\end{array}$ & $\begin{array}{l}\text { Dosis/respons skadesfunktion på } \\
\text { sundhed og fremskyndet døde- } \\
\text { lighed (SFT, 2000) }\end{array}$ & 565 & 1.245 \\
\hline Kemikalier (g) & & 2.300 .000 & 6.400 .000 \\
\hline $\begin{array}{l}\text { Dioxi- } \\
\text { ner }\end{array}$ & $\begin{array}{l}\text { Dosis/respons, indeks for sund- } \\
\text { hedsskader }\end{array}$ & 951 & 2.033 \\
\hline $\begin{array}{l}\text { Øvrige } \\
\text { stoffer }\end{array}$ & Dosis/respons & 95 & \\
\hline
\end{tabular}

Kilde: ECON (2000)

På grund af forskelle i beregningsforudsætninger er nogle af beregningspriserne i tabel 2 opgjort som henholdsvis lavt, bedste og højt skøn. Dette gælder f.eks. for skadesomkostningerne ved udledningen af $\mathrm{CO}_{2}$, hvor det bedste skøn forudsætter, at værdien af statistisk liv (VSL) er 12 mio. NOK. I beregningerne af det højeste skøn forudsættes det, at værdien af statistisk liv er 30 mio. NOK. Som beregningspris for skadesomkostningerne ved udledningen af $\mathrm{CO}_{2}$ anvendes den forventede kvotepris på det internationale marked for udledningskvoter af $\mathrm{CO}_{2}$.

For udledningen af andre gasser $\left(\mathrm{SO}_{2}, \mathrm{NO}_{\mathrm{x}}\right.$ og VOC) og partikler er beregningspriserne for skadesomkostningerne fremkommet på forskellige måder. For $\mathrm{SO}_{2}$ er beregningsprisen lig med den generelle sats for den norske svovlafgift på $17 \mathrm{NOK}$ pr. kg udledt $\mathrm{SO}_{2} \mathrm{i}$ forbindelse med anvendelsen af mineralolier. Som beregningspriser for skadesomkostningerne ved udledninger af $\mathrm{NO}_{\mathrm{x}}$ og VOC anvendes de forventede renseomkostninger på 15 NOK pr. kg udledt $\mathrm{NO}_{\mathrm{x}}$ og 4 NOK pr. kg udledt VOC for, at Norge kan opfylde sine forpligtelser i Gøteborg-protokollen om reduktioner i udledningerne af forskellige stoffer. Det bedste skøn for beregningsprisen for partikler på 565 NOK pr. kg udledt $\mathrm{PM}_{10}$ er beregnet som et simpelt gennemsnit af det laveste og det højeste estimat af nogle beregninger, der er gennemført på baggrund af tidligere beregninger af Statens Forurensningstilsyn (SFT, 2000; ECON, 2000: 50-57).

\footnotetext{
14 "Rapporten (SFT, 2000, red.) gir anslag for helseskader og framskyndet dødelighet. Den ser ikke på alle helseeffekter, og omhandler bl.a. ikke kreft" (ECON, 2000: 51).
} 
Tabel 3: Samfundsøkonomiske skadesomkostninger ved udledning af miljø- og sundhedsfarlige kemikalier til luft fra affaldsforbrænding

\begin{tabular}{|l|l|l|l|l|l|l|l|l|}
\hline & $\begin{array}{l}\text { Papir/ } \\
\text { pap }\end{array}$ & Plast & $\begin{array}{l}\text { Våd/or } \\
\text { ganisk }\end{array}$ & Metal & Glas & Træ & Tekstil & $\begin{array}{l}\text { Blandet } \\
\text { hush. } \\
\text { affald }\end{array}$ \\
\cline { 2 - 10 } & \multicolumn{6}{|l|}{ NOK pr. ton affald forbrændt } & \multicolumn{5}{l|}{} \\
\hline $\begin{array}{l}\text { Di- } \\
\text { oxin }\end{array}$ & 17 & 17 & 67 & 0 & 0 & 17 & 48 & 33 \\
\hline PAH & 3 & 3 & 6 & 0 & 0 & 3 & 0 & 2,5 \\
\hline $\mathrm{As}$ & 1 & 0,5 & 4 & 2 & 0,5 & 2 & 1 & 2 \\
\hline $\mathrm{Cd}$ & 1,5 & 3,5 & 5 & 0,5 & 0,5 & 0,5 & 4 & 5 \\
\hline $\mathrm{Cr}$ & 13 & 12 & 687,5 & 554,5 & 9 & 5 & 917 & 288 \\
\hline $\mathrm{Cu}$ & 0,1 & 0,1 & 0,1 & 0,5 & 0,1 & 0,1 & 0,1 & 0,2 \\
\hline $\begin{array}{l}\mathrm{Pb} \\
(\mathrm{bly})\end{array}$ & 3 & 3 & 58,5 & 18,5 & 29 & 3,5 & 7,5 & 37 \\
\hline $\mathrm{Mn}$ & 492 & 492 & 492 & 492 & 492 & 492 & 492 & 492 \\
\hline $\mathrm{Hg}$ & 0,1 & 0,1 & 0,7 & 0,7 & 0,05 & 0,1 & 1 & 2,5 \\
\hline $\mathrm{Ni}$ & 14 & 14 & 14 & 14 & 14 & 14 & 14 & 14 \\
\hline $\mathrm{Sb}$ & 5,5 & 5,5 & 5,5 & 5,5 & 5,5 & 5,5 & 5,5 & 5,5 \\
\hline $\mathrm{Se}$ & 0,5 & 0,1 & 2,5 & 0,5 & 0,1 & 0,1 & 0,5 & 1 \\
\hline $\mathrm{Sn}$ & 0 & 0 & 0 & 0 & 0 & 0 & 0 & 0 \\
\hline $\mathrm{V}$ & 0,1 & 0,1 & 0,1 & 0,1 & 0,1 & 0,1 & 0,1 & 0,1 \\
\hline $\mathrm{Zn}$ & 0 & 0 & 0 & 0 & 0 & 0 & 0 & 0 \\
\hline $\mathrm{Be}$ & 0,1 & 0,1 & 0,1 & 0,1 & 0,1 & 0,1 & 0,1 & 0,1 \\
\hline $\mathrm{HCl}$ & 1 & 3 & 13 & 0 & 1,5 & 0,5 & 3,5 & 5 \\
\hline $\mathrm{HF}$ & 0 & 59,5 & 59,5 & 59,5 & 59,5 & 59,5 & 59,5 & 39,5 \\
\hline $\mathrm{Sum}$ & 552 & 613,5 & $1.415,5$ & $1.146,5$ & 612 & 603 & 1.554 & 930,5 \\
\hline
\end{tabular}

Kilde: ECON, 2000

Skadesomkostningerne ved udledningerne af miljø- og sundhedsfarlige kemikalier fra affaldsbehandling er beregnet med udgangspunkt $i$ en rangordning af kemikaliernes skadespotentiale, der er udviklet til brug i forbindelse med livscyklusundersøgelser (Life-Cycle Assessment (LCA)). Indeksene, der er udviklet af det hollandske institut for folkesundhed og miljø (Rijksinstituut voor Volksgezondheid en Milieu (RIVM)) og Center for miljøvidenskab ved Leiden Universitet (Centrum voor Milieukunde (CML)), vurderes at repræ- 
sentere den nyeste viden om skadeseffekterne ved udledning af miljø- og sundhedsfarlige kemikalier (ECON, 2000: 61).

For at kunne prissætte skadesomkostningerne ved udledningen af de forskellige kemikalier på baggrund af de forskellige indeks er det nødvendigt, at der findes en beregningspris for skadesomkostningerne ved et af kemikalierne, som beregningspriserne for de øvrige kemikalier herefter kan beregnes ud fra. I beregningerne af skadesomkostningerne ved udledningen af miljø- og sundhedsfarlige kemikalier benyttes bl.a. indeks, der anvender bly $(\mathrm{Pb})$ som referencestof (ECON, 2000: 59).

Skadesomkostninger ved udledning af miljø- og sundhedsfarlige kemikalier til luften er i tabel 3 beregnet for forbrændingen af 1 ton af forskellige affaldsfraktioner. Beregningerne viser, at skadesomkostningerne er mindst for forbrændingen af 1 ton papir/pap (552 NOK) og størst for tekstil (1.554 NOK). For blandet husholdningsaffald er skadesomkostningerne 931 NOK pr. ton.

Af tabellen fremgår det endvidere, at 80-90 \% af skadesomkostningerne ved udledningen af kemikalierne skyldes mangan (Mn) og krom (Cr), hvilket hænger sammen med de store udledninger af stofferne i Norge i perioden 1996-1998 (ECON, 2000: 14 og 70).

Tabel 4: Samfundsøkonomiske skadesomkostninger ved udledning af dioxin til luft fra affaldsforbrænding

\begin{tabular}{|l|l|l|l|l|}
\hline \multirow{2}{*}{} & Vennemo (1995) & $\begin{array}{l}\text { Starring og Ven- } \\
\text { nemo (1997) }\end{array}$ & $\begin{array}{l}\text { Øko-indikator 99 } \\
\text { /CML/RIVM- } \\
\text { indeks }\end{array}$ & $\begin{array}{l}\text { Øko-indikator 99 } \\
\text { /CML/RIVM- } \\
\text { indeks }\end{array}$ \\
\cline { 2 - 5 } & \multicolumn{2}{|c|}{ NOK pr. gram udledt dioxin (2000-prisniveau) } \\
\hline $\begin{array}{l}\text { Dioxin } \\
(2,3,7,8- \\
\text { TCDD) }\end{array}$ & & & 69.000 & 170.000 \\
\hline $\begin{array}{l}\text { Dioxiner } \\
\text { Værdi af } \\
\text { statistisk } \\
\text { liv } \\
\text { (VSL) }\end{array}$ & 39 mio. NOK & ikke oplyst & 12 mio. NOK & 30 mio. NOK \\
\hline
\end{tabular}

Kilde: Vennemo, 1995; Staring og Vennemo, 1997; ECON, 2000

I tabel 4 er de beregnede samfundsøkonomiske skadesomkostninger ved udledningen af 1 gram dioxin vist. Forskellen mellem skadesomkostningerne ved udledningen af dioxin (2,3,7,8-TCDD) ved hjælp af Øko-indikator 99/CML/RIVM-indekset skyldes forskelle i forudsætningen om værdien af et statistisk liv (VSL). Beregningerne er gennemført for

${ }^{15} \operatorname{ECON}(2000: 52$ og 58). 
VSL på 12 og 30 mio. NOK. Når Vennemo (1995) og Starring og Vennemo (1997) når frem til betydeligt større skadesomkostninger, skyldes det, at deres beregninger er foretaget for de samlede udledninger af dioxiner ved forbrænding af affald og ikke kun for 2,3,7,8-TCDD.

\subsection{Prissætning af sundhedsskader ved udledning af skadelige stoffer}

Nogle af de samfundsøkonomiske effekter ved udledningen af skadelige stoffer fra affaldsbehandling viser sig bl.a. i form af øget sygefravær og -behandling, reduceret arbejdsproduktivitet og fremskyndet dødelighed (ECON, 2001:19). Forudsætningen om værdien af et statistisk liv er derfor central i mange samfundsøkonomiske analyser af sundhedseffekterne ved udledningen af de skadelige stoffer.

I dette afsnit er forskellige metoder til at beregne skadesomkostningerne på sundhed ved udledningen af skadelige stoffer beskrevet nærmere. F.eks. anvendes i ECON (2000 og 2001) 12 mio. NOK som det bedste skøn ('hovedalternativet') og 30 mio. NOK som det højeste skøn. Begge skøn stammer fra anbefalinger i tidligere publikationer. ${ }^{16}$

En del af kritikken af anvendelsen af VSL i samfundsøkonomiske analyser skyldes bl.a. en uheldig terminologi. Som det fremhæves i Pearce og Howarth (2000:40), er VSL ikke et forsøg på at afdække folk betalingsvillighed for at undgå at dø på et bestemt tidspunkt, men derimod summen af en række individers betalingsvillighed for en mindre reduktion $i$ en given risiko, f.eks. risikoen for fremskyndet dødelighed som følge af øget luftforurening.

Udover den uheldige terminologi er anvendelsen af VSL i samfundsøkonomiske analyser af sundhedseffekterne ved udledningen af skadelige stoffer bl.a. blevet kritiseret for, at sundhedsgevinsterne baseret på VSL er så dominerende i cost-benefit analyser, og at VSL er ens for unge og gamle mennesker. Kritikken af VSL har ført til udviklingen af en anden beregningsmetode for de samfundsøkonomiske skadesomkostninger - værdien af et livsår ('Values of Life Years' (VOLY)), hvor betalingsvilligheden for f.eks. reduktionen i risikoen for fremskyndet dødelighed ved luftforurening forudsættes at være afhængig af den tilbageværende levetid. Der synes ikke at være nogen konsensus om anvendelsen af de to metoder. Da VSL-metoden medfører de højeste estimater, anvendes den ofte som forudsætning i forbindelse med beregninger af det højeste skøn i følsomhedsberegninger af de samfundsøkonomiske skadesomkostninger, som det f.eks. er tilfældet i beregninger i ECON (2000; 2001).

\subsection{Samfundsomkostninger ved udledning af kemikalier fra affaldsforbrænding}

I dette afsnit er betydningen af at inddrage de samfundsøkonomiske skadesomkostninger ved udledning af miljø- og sundhedsfarlige kemikalier beskrevet nærmere med udgangspunkt i ovennævnte ECON-rapport om skadesomkostningerne ved affaldsbehandling i

\footnotetext{
${ }^{16}$ Statens Forurensningstilsyn (SFT) (2000) og Kostnadsberegningsutvalget (1998).
} 
Norge (ECON, 2000). Der kan forekomme skader på miljø og sundhed ved udledningen af selv meget små kemikaliemængder, da stofferne er langsomt nedbrydelige og akkumuleres i fødekæden. Sundhedseffekterne ved udledning af dioxiner ved affaldsbehandling er beskrevet nærmere i kapitel 3.

Tabel 5: Samfundsøkonomiske skadesomkostninger ved udledninger fra forbrænding af affald med den eksisterende teknologi

\begin{tabular}{|l|l|l|l|l|l|l|l|l|l|}
\hline & $\begin{array}{l}\text { Papir/ } \\
\text { pap }\end{array}$ & Plast & $\begin{array}{l}\text { Våd- } \\
\text { orga- } \\
\text { nisk }\end{array}$ & Metal & Glas & Træ & Tekstil & $\begin{array}{l}\text { Blandet } \\
\text { hush.- } \\
\text { affald }\end{array}$ \\
\cline { 2 - 9 } & \multicolumn{2}{|l|}{ NOK pr. ton affald forbrændt } & & & & & & \\
\hline $\begin{array}{l}\text { Driv- } \\
\text { hus- } \\
\text { gasser }\end{array}$ & 3 & 353 & 1 & 0 & 0 & 1 & 120 & 39 \\
\hline $\begin{array}{l}\text { Andre } \\
\text { gasser/ } \\
\text { partik- } \\
\text { ler }\end{array}$ & 81,5 & 101 & 93,5 & 51,5 & 58 & 72,5 & 115 & 79,5 \\
\hline $\begin{array}{l}\text { Kemi- } \\
\text { ka-lier }\end{array}$ & 552 & 613,5 & $1.415,5$ & $1.146,5$ & 612 & 603 & 1.554 & 930,5 \\
\hline Sum & 636,5 & $1.067,5$ & 1.510 & 1.198 & 670 & 676,5 & 1.789 & 1.049 \\
\hline
\end{tabular}

Kilde: ECON, 2000

I tabel 5 er de samfundsøkonomiske skadesomkostninger ved udledninger fra forbrænding af forskellige affaldsfraktioner opdelt på skadesomkostningerne ved udledning af drivhusgasser, andre gasser og partikler samt miljø- og sundhedsfarlige kemikalier. Omkostningerne ved udledning af kemikalier i tabel 5 svarer til summen af skadesomkostninger i tabel 3. De samlede skadesomkostninger er beregnet til at være mindst for forbrændingen af 1 ton papir/pap (637 NOK) og størst for tekstil (1.789 NOK). ${ }^{17}$ For blandet husholdningsaffald er skadesomkostningerne ved forbrænding 1.049 NOK pr. ton.

Til sammenligning kan det nævnes, at den norske afgift på forbrænding af affald, der i princippet bør afspejle de samfundsøkonomiske skadesomkostninger ved udledningerne fra affaldsforbrændingen, i 2001 varierede fra 79 til 314 NOK afhængigt af graden af forbrændingsanlæggets energiudnyttelse (Dengsøe, 2001: 9).

For alle affaldsfraktioner bortset fra plastaffald, tekstil og husholdningsaffald udgør omkostningerne ved udledningen af drivhusgasserne $\mathrm{CO}_{2}$ og metan $\left(\mathrm{CH}_{4}\right)$ en ubetydelig del

\footnotetext{
${ }^{17}$ Beregningerne er ligeledes gennemført for forbrænding af imprægneret træ (ikke vist). De samlede samfundsøkonomiske skadesomkostninger er i ECON (2000: 82) beregnet til 3.056 NOK pr. ton affald forbrændt.
} 
af de samlede skadesomkostninger. Den anvendte beregningspris på 130 NOK pr. ton udledt $\mathrm{CO}_{2}$ er fremkommet som den forventede kvotepris i forbindelse med handlen med $\mathrm{CO}_{2}$-udledninger (ECON, 2000: 48). Beregningsprisen for skadesomkostningerne ved udledning af metan $\left(\mathrm{CH}_{4}\right)$ er 21 gange større, hvilket afspejler forskellen i de to drivhusgassers globale opvarmningspotentiale ('Global Warming Potential' (GWP)). Skadesomkostningerne ved udledning af drivhusgasser er mindst for metal og glas (0 NOK) og størst i forbindelse med forbrændingen af 1 ton plastaffald (353 NOK). For udledningen af andre gasser $\left(\mathrm{NO}_{\mathrm{x}}, \mathrm{SO}_{2}\right.$ og VOC) og partikler er skadesomkostningerne mindst for metal (52 NOK) og størst for tekstil (115 NOK).

For alle affaldsfraktioner bortset fra plastaffald udgør omkostningerne ved udledningen af de miljø- og sundhedsfarlige kemikalier mellem 85 og 95 procent af de samlede skadesomkostninger ved forbrænding af de forskellige affaldsfraktioner (ECON, 2000: 81). ${ }^{18}$ Som det fremgik af afsnit 2, skyldes 80-90 procent af skadesomkostningerne udledningen af de skadelige stoffer mangan (Mn) og krom $(\mathrm{Cr})$. Det er derfor helt afgørende, at effekterne af de miljø- og sundhedsfarlige kemikalier indgår i en samfundsøkonomisk analyse af affaldsbehandling.

\subsection{Opsummering}

I dette kapitel er det beskrevet, hvordan det er muligt at udarbejde en samfundsøkonomisk analyse af skadesomkostningerne ved affaldsbehandling, herunder affaldsforbrænding. I kapitlet er der gjort rede for forskellige prissætningsmetoder, og resultaterne af nogle omfattende norske undersøgelser af affaldsbehandling er beskrevet nærmere. Af undersøgelserne fremgår det, at det er helt afgørende at inddrage omkostningerne ved udledningen af de miljø- og sundhedsfarlige kemikalier i en samfundsøkonomisk analyse af affaldsbehandling, da de for stort set alle affaldsfraktioners vedkommende udgør mellem $85 \operatorname{og} 95 \%$ af de samlede skadesomkostninger ved forbrænding af fraktionerne.

\footnotetext{
${ }^{18}$ For forbrændingen af plastaffald udgør skadesomkostningerne fra de miljø- og sundhedsfarlige kemikalier 57,5 procent.
} 


\section{Mortalitets- og morbiditets- effekter ved dioxiner}

\subsection{Introduktion}

Der er generel enighed blandt de epidemiologer, der beskæftiger sig med effekten af dioxiner på menneskers helbred, om, at indtag af dioxiner kan forårsage en lang række negative helbredseffekter, såsom nedsat sædkvalitet, udviklingsmæssige effekter, hudsygdomme, leversygdomme og ikke mindst forskellige kræfttyper (IEH, 1997; US-EPA, 2000; Fiedler et al., 2000). Til gengæld er der stor uenighed om størrelsen af disse effekter og sandsynligheden for deres indtræden, hvorfor de tilhørende omkostningsestimater for dioxinernes effekter har varieret en del i forskellige undersøgelser (CEC, 2000:36). Det er derfor meget vigtigt at få diskuteret det foreliggende vidensgrundlag for netop denne gruppe stoffer, hvis det skal være muligt at vurdere de samlede omkostninger ved affaldsbehandling.

Dioxinforbindelserne bindes til fedt, hvorfor mennesker primært eksponeres via indtagelse af f.eks. æg, kylling og især kød og fisk (Fiedler et al., 2000:34). Problemet er, at dioxiner har en relativt lang halveringstid (ca. 5,8-9,6 år) i forhold til menneskers gennemsnitslevealder og langsomt oplagres i kroppen. Eventuelle skadelige effekter ved dioxineksponering vil derfor normalt opstå efter længere tids påvirkning. Af denne grund beregnes de skadelige effekter ofte som et resultat af en bestemt dioxinmængde i kroppen snarere end et bestemt indtag.

Boks 1: Opgørelser af dioxin

Betegnelsen "dioxiner" dækker over en gruppe på ca. 75 forbindelser eller stoffer, der er opbygget af bl.a. carbon, ilt og klor (CEC, 1997b; IEH, 1997). Dioxinbegrebet dækker ofte også over de såkaldte furaner, der er en gruppe på ca. 135 stoffer eller forbindelser. De mange stoffer inden for gruppen dioxiner har forskellige grader af giftighed i forhold til menneskers indtag. Som oftest har undersøgelser derfor været relateret til den farligste af forbindelserne - 2,3,7,8-tetrachlorodibenzo-p-dioxin. Denne forbindelse kaldes også "Seveso-dioxin", fordi forskere blev særligt opmærksomme på den efter et kraftigt udslip ved en ulykke i den italienske by Seveso i 1976. En udlednings giftighed vægtes i forhold til "Seveso-dioxin" ved hjælp af såkaldte toksicitetsækvivalenter (TEQ), der er defineret af WHO. TEQ udtrykker således giftigheden af de enkelte dioxintyper i forhold til giftigheden af 2,3,7,8-TCDD. TEQ udregnes ved at multiplicere koncentrationen af hver dioxintype med en toksicitetsfaktor (TEF). 
Betegnelsen I-TEQ inkluderer alene dioxiner og furaner (US-EPA, 2000 vol. 2/part 1:1-5ff.). I 1994 opstillede WHO en ny enhed - TEQ - der udover dioxiner og furaner også inkluderer 13 dioxinlignende PCB-stoffer. På baggrund af den nyeste viden blev enheden TEQ revideret i 1998. Dette betød bl.a. at de oprindelige forhold mellem dioxiner og furaner blev ændret. I de fleste danske rapporter anvendes betegnelsen WHOTEQ, idet det samtidig angives, om PCB regnes med eller ej (Fødevaredirektoratet \& Plantedirektoratet, 2001). WHO-TEQ inklusive PCB svarer til enheden TEQ fra 1998. Til gengæld er I-TEQ ikke helt det samme som WHO-TEQ eksklusive PCB, fordi de to toksicitetsækvivalenter anvender forskellige toksicitetsfaktorer for dioxiner og fura-

Figur 1: Forskellige dosis-respons sammenhænge

Respons $\quad$ Funktion med 'gødskningseffekt'

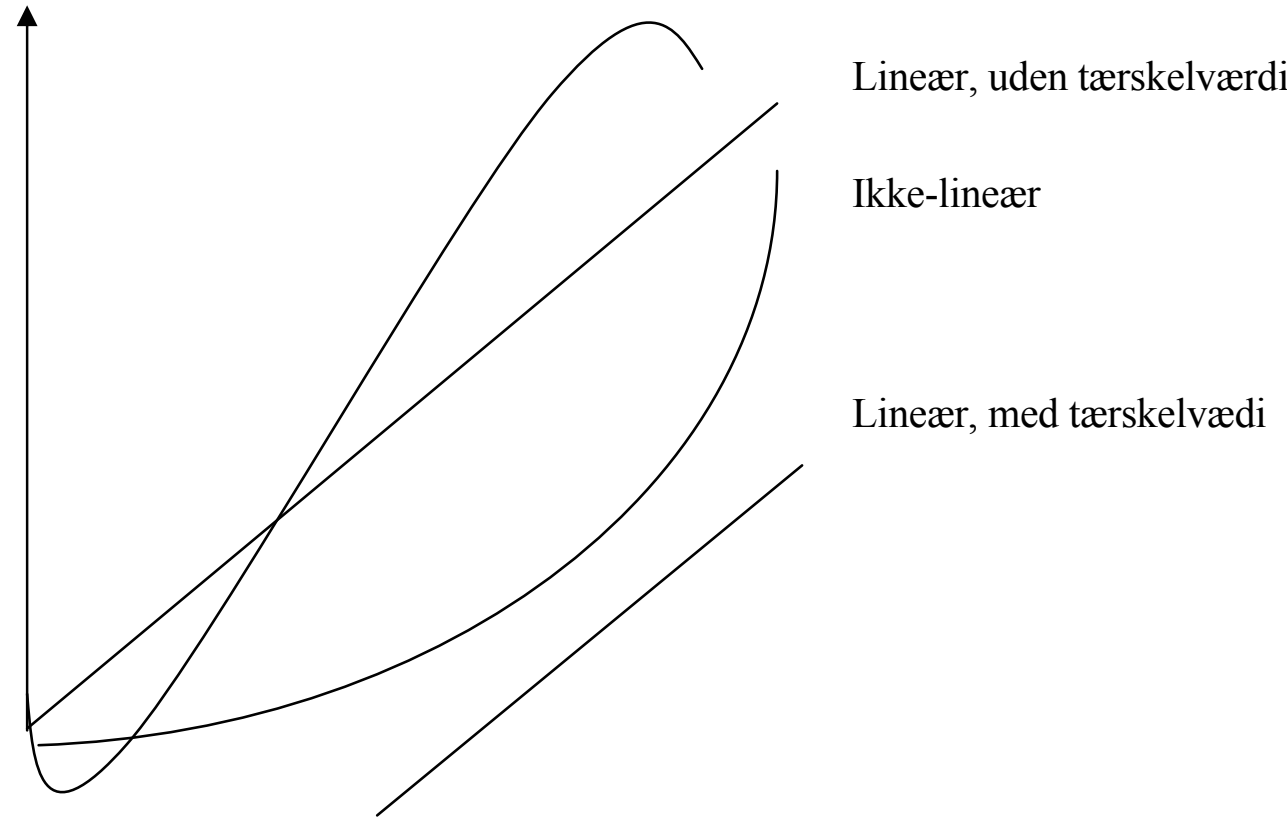

Dosis

Kilde: Holland et al. 1999: 30

Der er uenighed blandt epidemiologer om, hvorvidt der findes en grænsetærskel for, hvornår indtag af dioxin medfører skadelige helbredseffekter, dvs. om et dagligt dioxinindtag er uskadeligt, hvis blot det ligger under en bestemt grænse. Her er der især uenighed imellem EU og USA, idet førstnævnte generelt accepterer en minimumstærskel, mens amerikanerne antager, at en sådan tærskel er ekstremt lav eller ikke-eksisterende. Hertil kommer, at der er uenighed om, hvor en eventuel tærskel ligger. I 1998 ændrede WHO 
sin anbefaling fra et dagligt maksimumsindtag på 10 picogram TEQ $/ \mathrm{kg}$. kropsvægt til et tolerabelt dagligt indtag på 1-4 picogram TEQ $/ \mathrm{kg}$. kropsvægt med det mål at komme under 1 picogram TEQ/kg.kropsvægt/dag (WHO, 1999:21; Cederberg, Larsen \& Ovesen, 1999). ${ }^{19}$

Dette repræsenterer en gennemsnitlig livstidsdosis for hvilken, der ikke formodes at være skadelige helbredseffekter. I løbet af 2000 gennemførte Task Force on Dioxins fra EU's videnskabelige komité for Levnedsmidler (SCF) en vurdering af det foreliggende materiale om risici ved dioxiner (Fødevaredirektoratet \& Plantedirektoratet, 2001:30). Her blev der anbefalet et niveau for tolerabelt dagligt indtag på 7 picogram TEQ/kg kropsvægt pr. uge (ca. 1 picogram/kg. kropsvægt/dag).

Der er desuden uenighed om formen på dosis/respons-kurven. Hermed menes sammenhængen mellem den optagne dioxinmængde og de eventuelle helbredseffekter. I relation til kræft antager én gruppe forskere - herunder den amerikanske miljøstyrelse - at der er en lineær sammenhæng mellem indtag og effekter (Rabl, Spadaro \& McGavran, 1998; US-EPA, 2000). En anden gruppe forskere mener ikke, at dette er tilstrækkeligt påvist. Det hedder således i den nyeste rapport fra Europakommissionen: "The risk assessment of US EPA is unique in that it assumes a linear dose/response relationship for dioxininduced cancer, which is usually only assumed for carcinogens which damage the genetic material (DNA)" (CEC \& DETR, 1999/task 8:14f.). Alternativt kunne man forestille sig, at sammenhængen var f.eks. kurveformet (se figur 1).

I tabel 6 gives en oversigt over det antagede gennemsnitlige indtag af dioxin i Danmark og en række andre lande. Fødevaredirektoratet og Plantedirektoratet har udregnet, at gennemsnitsdanskeren i alt indtager ca. 0,7 picogram WHO-TEQ/kg. kropsvægt/dag eksklusiv PCB og 1,7 picogram WHO-TEQ/kg. kropsvægt/dag inklusiv dioxinlignende PCB'er (dvs. lig TEQ) (Fødevaredirektoratet \& Plantedirektoratet, 2001:23). Indtaget varierer meget afhængigt af kostvanerne, såsom f.eks. andelen af fisk i kosten.

Tabel 6: Gennemsnitligt dagligt indtag af dioxin ${ }^{20}$

\begin{tabular}{|l|l|l|l|l|}
\hline Land & $\begin{array}{l}\text { Under- } \\
\text { søgel- } \\
\text { ses- } \\
\text { tids- } \\
\text { punkt }\end{array}$ & $\begin{array}{l}\text { Indtag } \\
\text { (pg /kg. kropsvægt) } \\
\text { ekskl. PCB }\end{array}$ & $\begin{array}{l}\text { Indtag } \\
\text { (pg /kg. kropsvægt) } \\
\text { TEQ (inkl. PCB) }\end{array}$ & Reference \\
\hline Danmark $^{22}$ & 2001 & $0,7-0,8$ WHO-TEQ & 1,7 & $\begin{array}{l}\text { Fødevaredirektora- } \\
\text { tet \& Plantedirekto- } \\
\text { ratet, 2001 }\end{array}$ \\
\hline
\end{tabular}

\footnotetext{
${ }^{19} 1$ gram $=1$ million mikrogram $\left(10^{6}\right)=1$ milliard nanogram $\left(10^{9}\right)=1$ tusind milliarder picogram $\left(10^{12}\right)$. Bemærk, at 1 picogram dioxin/2,3,7,8-TCDD ikke er lig 1 picogram TEQ.

${ }^{20}$ Der antages i hovedreglen en person på ca. $70 \mathrm{~kg}$.

${ }^{21}$ Da WHO-TEQ ekskl. PCB og I-TEQ som nævnt ikke er ens, angives toksicitetsækvivalenten.
} 


\begin{tabular}{|l|l|l|l|l|}
\hline Norge & 1997 & $0,8-1,4^{*}$ & $2,3-3,2$ & $\begin{array}{l}\text { Cederberg, Larsen } \\
\& \text { Ovesen, 1999 }\end{array}$ \\
\hline Sverige & 1997 & $1,8-2,5^{*}$ & $4,1-4,8$ & $\begin{array}{l}\text { Cederberg, Larsen } \\
\& \text { Ovesen, 1999 }\end{array}$ \\
\hline Tyskland & 1996 & $1,0^{*}$ & & $\begin{array}{l}\text { Cederberg, Larsen } \\
\& \text { Ovesen, 1999 }\end{array}$ \\
\hline UK & 1999 & $1,6-2,9^{*}$ & $2,6-5,6$ & $\begin{array}{l}\text { Cederberg, Larsen } \\
\& \text { Ovesen, 1999 }\end{array}$ \\
\hline $\begin{array}{l}\text { EU (gen- } \\
\text { nemsnit) }\end{array}$ & 1999 & $0,9-3,0$ I-TEQ & & $\begin{array}{l}\text { CEC \& DETR, } \\
1999 / \text { task 4:17 }\end{array}$ \\
\hline USA & 2000 & & $1-3$ & $\begin{array}{l}\text { US-EPA, 2000/part } \\
\text { III }\end{array}$ \\
\hline
\end{tabular}

Kilde: Fødevaredirektoratet \& Plantedirektoratet, 2001:23ff.; Cederberg, Larsen \& Ovesen, 1999; US-EPA, 2000/part III

* Ikke angivet, om der er tale om I-TEQ eller WHO-TEQ ekskl. PCB

Gennemsnitsindtaget i EU skønnes at være ca. 0,9-3,0 picogram I-TEQ/kg. kropsvægt/dag, når der antages en gennemsnitlig kropsvægt på $70 \mathrm{~kg}$ (CEC \& DETR, 1999/task 4:17). I gennemsnit er dioxineksponeringen faldet ca. 12\% pr. år i hele EU i løbet af de sidste to årtier. Dette markante fald skyldes bl.a. ændrede regler for udledning samt ændrede spisevaner.

En sammenligning af dioxinindtaget opgjort i TEQ sammenlignet med anbefalingen fra WHO viser, at gennemsnitsindtaget i de fleste lande ligger meget tæet på eller over det anbefalede maksimale indtag fra WHO på 4 picogram TEQ/kg.kropsvægt/dag. Det høje indtag i Sverige skyldes bl.a., at fisk udgør en stor del af føden (Cederberg, Larsen \& Ovesen, 1999).

Udover de anførte gennemsnitsværdier må det overvejes, at mange spædbørn via modermælken indtager op til 100 picogram/ kg. kropsvægt pr. dag, hvilket er langt over det anbefalede. Det må derfor i relation til forsigtighedsprincippet betragtes som relevant at undersøge betydningen af helbredseffekterne ved dioxiner skabt ved affaldsforbrænding (se boks 2).

\footnotetext{
${ }^{22}$ Dette skøn har ændret sig de sidste år. I 1997 blev indtaget f.eks. opgjort til 2,44 I-TEQ/kg. kropsvægt/dag (Miljøstyrelsen, 1997:63).
} 


\section{Boks 2: Forsigtighedsprincippet}

Forsigtighedsprincippet stammer fra Tyskland (das Vorsorge-prinzip), hvorfra det har bredt sig til en række internationale sammenhænge - det er bl.a. indskrevet i Maastricht-traktaten i 1992 (Andersen, 2000). Indholdet i princippet er, at miljøbelastninger kun kan undgås gennem en forebyggende indsats, som udstikkes gennem en overordnet og langsigtet planlægning. Hvordan dette konkret skal fortolkes, er der givet mange bud på. Det er bl.a. anført, at man i kraft af forsigtighedsprincippet kan argumentere for at reducere risiko ved simpel risikomistanke (mulige, men ikke sikre skader). Dette har betydning for nærværende analyse af dioxiners effekter, idet der med baggrund i princippet kan argumenteres for at benytte værdier, der peger på de højest mulige skadeseffekter og dermed de højeste omkostninger.

apporten fra Fødevaredirektoratet og Plantedirektoratet (2001) angiver, hvilken mængde dioxin de enkelte fødevaregrupper giver anledning til (tabel 7). Som det fremgår, er fisk og mejeriprodukter de to væsentligste kilder.

Tabel 7: Gennemsnitsdanskerens dioxinindtag fordelt på fødevarer

\begin{tabular}{|l|l|}
\hline Fødevare & $\begin{array}{l}\text { Gennemsnitligt dioxinindtag, picogram TEQ/kg. krops- } \\
\text { vægt/dag }\end{array}$ \\
\hline Mejeriprodukter & $0,57(41 \%)$ \\
\hline Eg & $0,04(3 \%)$ \\
\hline Kød & $0,18(13 \%)$ \\
\hline Fisk & $0,92(44 \%)$ \\
\hline I alt & 1,7 \\
\hline
\end{tabular}

Kilde: Fødevaredirektoratet \& Plantedirektoratet, 2001:25

Hvilke skadelige effekter, dioxinerne har på mennesker, er diskuteret og undersøgt i en lang række projekter. Effekterne opdeles som oftest $\mathrm{i}$ henholdsvis mortalitets- og morbiditetseffekter. Heraf er mortalitetseffekterne langt de væsentligste ud fra både en menneskelig og en samfundsøkonomisk betragtning. De to typer effekter gennemgås i det følgende. Som reference benyttes for det første en meget omfattende og detaljeret rapport fra den amerikanske miljøstyrelse (US-EPA, 2000). En foreløbig version af rapporten blev i 2000 lagt ud på styrelsens hjemmeside, men den angives stadig som et udkast, hvorfra der ikke må citeres. Da der imidlertid endnu ikke er kommet en endelig version, betragtes det som acceptabelt at anvende udkastet. Herudover inddrages bl.a. en rapport fra universitet $i$ Bayreuth om dioxiner i affald, der er udarbejdet for Europakommissionens Miljødirekto-

\footnotetext{
${ }^{23}$ Kilden anvender måleenheden WHO-TEQ tillagt PCB. Denne sættes dermed lig TEQ.
} 
rat (Fiedler et al., 2000), samt en rapport fra Europakommissionen, der omhandler effekten af dioxiner (CEC \& DETR, 1999). I nærværende undersøgelse anvendes generelt rapporter, som vurderer allerede foretagne eksperimenter eller undersøgelser frem for deciderede afrapporteringer fra forsøg.

Boks 3: Begreber vedrørende dioxineksponering

Menneskers eksponering over for dioxin opgøres som oftest på to forskellige måder: kropsbelastning (body burden) og dagligt indtag. Kropsbelastningen defineres som den antagede koncentration af dioxin i kroppen og udtrykkes typisk i nanogram $/ \mathrm{kg}$. kropsvægt. I modsætning hertil defineres det daglige indtag som det antagede gennemsnitlige daglige indtag af dioxin, og udtrykkes som oftest i picogram $/ \mathrm{kg}$. kropsvægt/dag. Forskellen skyldes, at dioxin har en halveringstid i kroppen på mellem 5,8 og 9,6 år (Fiedler et al., 2000:34; US-EPA, 2000:159).

\subsection{Mortalitetseffekter (dødelighed) ved dioxin}

En af de alvorligste sygdomsgrupper, der er sat i forbindelse med dioxinindtag, er kræft. Selvom kræft også hører til under morbiditetseffekterne, er det den væsentligste mortalitetsårsag ved dioxiner, hvorfor sygdommen i nærværende rapport placeres i denne kategori. I det følgende diskuteres derfor både undersøgelser, der har fokuseret på kræftrelaterede mortalitets- og morbiditetseffekter ved dioxin. I flere af nedenstående undersøgelser skelnes desuden ikke mellem dødelige og ikke-dødelige kræfttilfælde.

I rapporten fra den amerikanske miljøstyrelse opgøres effekterne i antal kræftdødsfald $\mathrm{i}$ stedet for antal kræfttilfcelde (US-EPA, 2000/part 2:8-22). Det er primært stoffet 2,3,7,8TCDD, der er blevet undersøgt, og som på basis af en række forskningsresultater betragtes som kræftfremkaldende (US-EPA, 2000:31). Flere andre dioxiner karakteriseres som "sandsynligvis kræftfremkaldende", men der er behov for flere empiriske undersøgelser, før en sammenhæng kan fastslås med sikkerhed.

Spørgsmålet om 2,3,7,8-TCDD's kræftfremkaldende egenskab er imidlertid meget omdiskuteret. Dette gælder såvel sikkerheden af som størrelsen på en sådan dosis/responssammenhæng. Der eksisterer tilsyneladende et skel mellem USA og Europa på dette område, idet amerikanerne betragter sammenhængen mellem dioxin og kræft som mere sikker end europæerne. Forskellen synes at skyldes forskellig vægt på og tiltro til de studier, der foreligger på området. Problemet med disse undersøgelser er bl.a., at sammenhænge ekstrapoleres fra høj- til lavdosispåvirkninger. Herved forstås, at der antages at være en lineær sammenhæng mellem eksponering og effekter, hvorved det er muligt at sige noget om effekterne ved små påvirkninger på baggrund af undersøgelser af effekterne ved høje påvirkninger. Derfor er især europæerne forsigtige med at opstille dosis/responssammenhænge. I en EU-rapport fra 1997 vedrørende dioxiners effekt på mennesker hed- 
der det således, at : "The tumour incidence increased primarily 20 years after the exposure. The epidemiological studies did not provide evidence of a dose/response relationship" (CEC, 1997:7). I rapporten fra 1999 fremføres det, at "For humans, several epidemiological studies on accidental and occupational exposure to dioxins and PCBs show evidence of an increased incidence of different tumours, but the low quality and/or power of the studies make them difficult to interpret" (CEC \& DETR, 1999/task 8:5).

Europæiske forskere anerkender dog, at en lang række undersøgelser tyder på en kræftfremkaldende effekt ved dioxiner, og at 2,3,7,8-TCDD er et stof, der virker kræftfremkaldende hos mennesker (et carcinogen) (IARC, 1997). I Fiedler et al. (2000:24) påpeges det, at fire epidemiologiske studier af grupper, der blev udsat for høje doser af dioxin, viser en forøgelse af kræftrisikoen. Dioxinkoncentrationen i de undersøgte industriarbejderes blod var mellem 301 og 3683 nanogram 2,3,7,8-TCDD/kg. kropsvægt. Enkelte havde op til 32.000 nanogram dioxin pr. kg. kropsvægt. Der er derfor tale om markant større mængder dioxin, end hvad den almindelige befolkning udsættes for som følge af affaldsforbrænding. Dyreforsøg viser, at den forøgede kræftrisiko kan opstå ved et indtag på ca. 100 nanogram 2,3,7,8-TCDD pr. kg. kropsvægt, hvilket dog stadig er meget højere end det normale gennemsnitlige indtag for mennesker.

Selvom det generelt understreges, at den stærkeste sammenhæng fremstår mellem dioxin og alle kræfttyper kombineret, fremføres desuden en række forskellige kræfttyper, der formodes at være relateret til dioxinindtag (CEC \& DETR, 1999/task 8:A4f.). Ti år efter ulykken i Seveso blev der konstateret en forøgelse i "soft tissue sarcomas" hos mænd (2,8\%) og leverkræft hos kvinder (3,3\%) (IEH, 1997:72f.). Desuden fremhæves især lungekræft, lymfekræft og kræft i spiserøret. Hertil kommer knoglemarvskræft, kræft i mundhulen, nyrekræft, leukæmi og brystkræft hos kvinder. Endvidere er der visse tegn på en øget risiko for endetarmskræft. Kræftrisikoen forøges generelt for begge køn. En tidlig undersøgelse af kræftrisikoen fra dioxiner udledt ved affaldsforbrænding viste en kræftrisiko over livstid på $1,8 \cdot 10^{-7}$ for hele befolkningen ved en eksponering på 0,0011 picogram TEQ/kg. kropsvægt pr. dag. Samtidig viste andre undersøgelser af arbejdere i den kemiske industri en tendens til en lineær sammenhæng mellem dioxin og kræftrisiko.

En omfattende undersøgelse fra Storbritannien fokuserede på en eventuel forøgelse af antallet af kræfttilfælde hos folk, der bor tæt på anlæg for affaldsforbrænding (Elliott et al., 1996). Undersøgelsen inkluderede 14 millioner mennesker og 72 affaldsforbrændingsanlæg. Til gengæld var der ingen data for, hvilke emissionstyper der var tale om (såsom dioxiner). Det var derfor ikke muligt at opstille dosis/respons-sammenhænge. Desuden var der tale om relativt gamle anlæg, der sandsynligvis har en markant højere udledning af skadelige stoffer end nyere anlæg. Der blev udregnet et forhold mellem antallet af observerede og forventede kræfttilfælde (dvs. en observed/expected-ratio). For alle kræfttyper kombineret blev der konstateret en overrepræsentation på 4 og 2\% afhængigt af, hvor langt man boede fra forbrændingsanlægget. For de enkelte kræfttypers vedkommende var især leverkræft (13\%) og lungekræft (8\%) kraftigt overrepræsenteret. Pga. socioøkonomiske variable og fejl i oplysningerne om dødsårsager konkluderes det imidlertid, at der ikke kan fastslås en forøget kræftrisiko ved at bo tættere på et affaldsforbrændingsanlæg. Samlet set er der derfor stadig ikke enighed om en dosis/respons-sammenhæng i Europa. 
I modsætning til europæerne har det været et mere bevidst formål med den amerikanske rapport at opstille en dosis/respons-sammenhæng for kræftrisikoen ved dioxiner (USEPA, 2000/part II:8-16ff.). Det konstateres i rapporten, at tre undersøgelser giver mulighed for en opstilling af lineære dosis/respons-sammenhænge mellem dioxinmængder og antal kræftdødsfald. Det drejer sig om NIOSH-studiet af amerikanske kemikalieindustriarbejdere, samt Hamburg-studiet og BASF-studiet af tyske kemikalieindustriarbejdere. Alle tre undersøgelser omfatter primært mænd.

Der anvendes som oftest to typer mål for kræftrisiko. For det første standard mortality ratio (SMR), der udtrykker differencen på kræftrisikoen mellem den eksponerede og ikke-eksponerede gruppe i en undersøgelse. For det andet udregnes en såkaldt effective do$s e_{01}$. Denne betegner den dosis (nanogram pr. kg. kropsvægt), der formodes at korrespondere til en risikoforøgelse for kræft på $1 \%$ over den gennemsnitlige risiko. Som uafhængig variabel (årsag) kan man på den ene side anvende størrelsen på eller længden af dioxineksponeringen og på den anden side anvende mængden af dioxin i blod eller væv. I relation til sidstnævnte har der imidlertid kun været tale om stikprøver, der var indsamlet årtier efter sidste eksponering. Dioxinmængden i blod eller væv ved eksponeringstidspunktet er derefter estimeret på baggrund af halveringstiden af dioxin. I rapporten fra den amerikanske miljøstyrelse regnes derfor med time average body burden (nanogram pr. kg kropsvægt pr. år) som uafhængig variabel og måleenhed.

Med udgangspunkt i de nævnte undersøgelser udledes det, at dioxineksponering medfører en kræftrelateret overdødelighed på 13-57 ud af 10.000 eksponerede pr. picogram $/ \mathrm{kg}$. kropsvægt pr. dag udover det almindelige baggrundsniveau af dioxin (US-EPA, 2000/part II:8-23). I beregningen er anvendt en gennemsnitlig baggrundsrisiko for at dø af kræft på $18,5 \%$. Opført i effective dose danner de tre undersøgelser grundlag for tre "lower bound" estimater på henholdsvis 39,9, 5,7 og 80,2 nanogram/kg. kropsvægt ${ }^{24}$. Ved hjælp af en såkaldt Poisson regression, kombineres dette i et samlet estimat på 47,2 nanogram $/ \mathrm{kg}$. kropsvægt (US-EPA, 2000/part III:97,148). Med andre ord stiger risikoen for et dødeligt kræfttilfælde med 1\% over det normale, når dioxinmængden i blodet er 47,2 nanogram $/ \mathrm{kg}$. kropsvægt, idet der dog som sagt er tale om en "lower bound"-vurdering, dvs. risikoen er lavt sat. Til sammenligning fandt WHO i 1998, at kræftrisikoen stiger til 1\% over det normale, når dioxinmængden i kroppen er 3-13 nanogram/kg kropsvægt svarende til et dagligt indtag på 2-7 picogram/kg kropsvægt/dag (WHO, 1999:12).

Problemet er, at en sådan opgørelse er svær at anvende i en marginalbetragtning, som der er behov for i denne rapport til at kunne vurdere den samfundsøkonomisk optimale størrelse for en afgift på forbrænding af affald. Her er interessen samlet om stigningen i antallet af kræfttilfælde som funktion af en stigende udledning af dioxin. Det er derfor interessant, at der udover "effective dose"-estimaterne også angives deciderede hældningskoeffi-

\footnotetext{
${ }^{24}$ Det antages, at 25\% af kropsvægten er fedt. Desuden antages halveringstiden for dioxinerne at være 7,1 år (US-EPA, 2000:part II, kap.8, s.16). En lavere antaget halveringstid ville resultere i en lavere "body burden" og dermed en lavere risiko og vice versa.
} 
cienter for sammenhængen mellem eksponering for dioxin og forøget kræftrisiko. ${ }^{25} \mathrm{Gen}$ nemsnittet for de tre undersøgelser sættes her til $1 \cdot 10^{-3}$ risiko/picogram TEQ $/ \mathrm{kg}$. kropsvægt pr. dag (US-EPA, 2000/part III:97). Dette betyder, at risikoen for at dø af kræft stiger med 0,001, når den daglige dioxineksponering stiger med 1 picogram TEQ pr. kg. kropsvægt. Det antages, at dette indtag sker hele livet igennem. Blandt 1000 eksponerede vil der således gennemsnitligt set være en mere, der dør af kræft, når den gennemsnitligt eksponering stiger med 1 picogram TEQ pr. kg. kropsvægt pr. dag. Denne risikovurdering antages at gælde både baggrundsniveau og gradvise indtag over dette niveau. Vurderingen må dog betragtes som meget høj i sammenligning med andre studier, hvilket bl.a. skyldes, at der er anvendt en "upper bound cancer risk", dvs. den højst mulige risiko.

Som det fremgår af tabel 6 , antages det gennemsnitlige daglige indtag i USA at være ca. 1-3 picogram TEQ/kg. kropsvægt/dag. Dette medfører en gennemsnitlig body burden på ca. 5 nanogram TEQ $/ \mathrm{kg}$. kropsvægt. Det anføres derfor i den amerikanske rapport, at det nuværende baggrundsniveau af dioxiner i blodet i USA overstiger risikoen for overdødelighed som følge af kræft (US-EPA, 2000/part III:105). I Danmark er det gennemsnitlige indtag af dioxiner som tidligere nævnt omtrent på niveau med det amerikanske. Såfremt man anvender den amerikanske risikovurdering på danske forhold, må dioxinindtaget $\mathrm{i}$ Danmark derfor også antages at medføre en overdødelighed. Det er dog uheldigt $\mathrm{i}$ forhold til en praktisk anvendelse af resultaterne, at der kun er inddraget dødelighed og ikke antal tabte livsår. Det er således forskelligt fra undersøgelse til undersøgelse, hvor mange år efter dioxineksponeringen antallet af dødelige kræfttilfælde er opgjort.

Selvom det understreges i den amerikanske vurdering, at den primære interesse er rettet mod en kombination af samtlige kræfttyper, diskuteres det dog også, om der kan konstateres en forøget risiko for enkelte kræfttyper (US-EPA, 2000/part II:7A-1ff.). Det viser sig, at der tilsyneladende er en forøget risiko for lungekræft i forhold til de øvrige kræfttyper. Der er således opgjort en specifik dosis/respons-sammenhæng for lungecancer. På baggrund af de tre nævnte undersøgelser udledes tre effective doses på henholdsvis 180, 36,6 og 250 nanogram $/ \mathrm{kg}$. kropsvægt. Desuden anføres det i US-EPA, at dyreforsøg har sandsynliggjort, at kræfttyper og -risiko ved dioxiner varierer i forhold til køn. Problemet er imidlertid som nævnt, at der kun foreligger ganske få undersøgelser, der inkluderer kvinder. Indtil bedre tal foreligger anvendes dosis/respons-sammenhængene fra de øvrige undersøgelser derfor på begge køn.

Af en nyligt publiceret artikel i tidsskriftet American Journal of Epidemiology fremgår det, at der jævnligt fremlægges nye undersøgelser og vurderinger af kræftrisikoen ved dioxin. En undersøgelse, der har studeret befolkningen fra Seveso-ulykken, finder, at der 20 år efter ulykken ikke kan konstateres en signifikant overdødelighed som følge af kræft (betragtet som alle typer under ét) (Bertazzi et al., 2001). Til gengæld viste det sig, at der var en overdødelighed som følge af især endetarms- og lungekræft blandt mænd 15 år efter ulykken. Et andet studie af amerikanske arbejdere fra en kemisk fabrik finder en positiv sammenhæng mellem kræft og eksponering for dioxin (Steenland et al., 2001). Det

\footnotetext{
${ }^{25}$ Dosis/respons-modellen beregnes ud fra kræftrisikoen for 2,3,7,8-TCDD alene, men i konklusionen på analysen opgives sammenhængen i TEQ. Sidstnævnte anvendes derfor i denne rapport.
} 
udledes, at risikoen for, at en mand dør af kræft ved et dagligt indtag af 2,3,7,8-TCDD på 1,0 picogram $/ \mathrm{kg}$. kropsvægt (over det gennemsnitlige baggrundsniveau på 0,5 picogram $/ \mathrm{kg}$. kropsvægt pr. dag), stiger til 0,05-0,9\% over den almindelige risiko for at dø af kræft (der sættes til 12,4\%). Dette svarer til 10 picogram TEQ/kg. kropsvægt pr. dag.

I Danmark har embedslægen Arne Poulstrup, Vejle Amt, undersøgt sammenhængen mellem kræfttilfælde (hudkræft undtaget) og luftbåren dioxinpåvirkning (Poulstrup \& Hansen, 2003). Sidstnævnte er operationaliseret ved at inddele befolkningen i områder, der har været udsat for forskellige dioxinniveauer som følge af udledning fra en nærliggende aluminiumsfabrik. Konklusionen på undersøgelsen er, at dioxinpåvirkningen ikke har ført til en forøget hyppighed af kræft. Det må dog anføres, at dioxinindtaget via luften er meget begrænset i forhold til indtaget via føden, hvorfor resultatet ikke nødvendigvis kan henføres til effekter ved det samlede dioxinindtag.

Ovenstående sammenligning af amerikanske og europæiske forskeres vurdering af kræftdødeligheden som følge af dioxineksponering viser tydeligt uenigheden og usikkerheden på området. Spørgsmålet er imidlertid, om ikke man må give den amerikanske miljøstyrelse ret $i$, at det er bedre at udnytte de foreliggende - om end usikre - undersøgelser til at opstille dosis/respons-sammenhænge end slet ikke at inddrage disse. Trods den enorme usikkerhed vil denne rapport derfor anvende den amerikanske dosis/respons-model, der antager, at risikoen for at dø af kræft stiger med 0,001, når den daglige dioxineksponering stiger med 1 picogram TEQ pr. kg. kropsvægt, såfremt dette indtag sker hele livet igennem.

Udover kræftrisikoen er det nævnt, at dioxin giver anledning til en forøget dødelig som følge af diabetes, hjerte-karsygdomme og ikke-ondartede leversygdomme (CEC \& DETR, 1999/task 8:A4). Der er dog ikke angivet dosis/respons-sammenhænge, hvorfor det ikke er muligt at inddrage disse mortalitetseffekter.

\subsection{Morbiditetseffekter (sygdomme) ved dioxin}

Der findes en lang række undersøgelser af og dermed en omfattende litteratur vedrørende morbiditetseffekterne ved dioxiner. Selvom der ikke er fuldstændig overensstemmelse mellem de forskellige inddragne rapporters vurdering af helbredseffekterne, lader det til, at der hersker knap så stor uenighed på dette område som vedrørende spørgsmålet om kræft. Til gengæld er den generelle usikkerhed om muligt endnu større for de fleste sygdommes vedkommende, og det har ikke været muligt at finde dosis/responssammenhænge. Vi har valgt at tage udgangspunkt i vurderingen fra den amerikanske miljøstyrelse, idet der er tale om en meget omfattende vurdering af et stort antal undersøgelser, og idet den er nyere end f.eks. WHO's dioxinvurdering fra 1998 (US-EPA, 2000/part II:7b-105ff.; WHO, 1999:21). Da der imidlertid ikke hersker generel konsensus om konklusionerne i denne rapport, anføres desuden vurderinger fra andre referencer.

Helbredseffekterne opdeles i tre grupper. For det første kan der udpeges nogle helbredseffekter, hvor to eller flere undersøgelser med rimelighed har påvist en sammenhæng med 2,3,7,8-TCDD (gruppe I). For det andet er der en gruppe symptomer, der sandsynligvis er relateret til 2,3,7,8-TCDD, men hvor en endelig evaluering af sammenhængen kræver yderligere undersøgelser (gruppe II). Endelig inkluderer den sidste gruppe de helbredsef- 
fekter, som er påvist ved dyreforsøg, men hvor menneskelige data kræver yderligere undersøgelser (gruppe III). De tre grupper af helbredseffekter er opstillet i tabel 8 herunder. Tabellen angiver vurderingen af sammenhængen fra den amerikanske rapport, hvorefter dette vurderes i forhold til andre rapporter.

Tabel 8: Menneskelige helbredseffekter af 2,3,7,8-TCDD-påvirkning (eksklusiv kræft)

\begin{tabular}{|c|c|c|c|}
\hline \multirow[t]{2}{*}{ Grp. } & \multirow[t]{2}{*}{ Helbredseffekt } & \multicolumn{2}{|c|}{ Sammenhæng med 2,3,7,8-TCDD ${ }^{26}$} \\
\hline & & US-EPA 2000 & Andre rapporter \\
\hline $\mathrm{I}$ & Klorakne (hudsygdom) & $\begin{array}{l}\text { Kan opstå over et vist min. } \\
\text { indtag, ophører oftest, når } \\
\text { eksponering ophører. } \\
\text { TCDD-niveauer på } 4 \text { pg/g } \\
\text { fedt har ikke medført klor- } \\
\text { akne }\end{array}$ & $\begin{array}{l}\text { Sammenhæng bekræftet i } \\
\text { (CEC, 1997:6; CEC \& } \\
\text { DETR, 1999/task 8:16f.; } \\
\text { Fiedler et al. 2000:23ff.) }\end{array}$ \\
\hline $\mathrm{I}$ & $\begin{array}{l}\text { Øget niveau af Gamma } \\
\text { Glutamyl Transferase } \\
\text { (risiko for leversygdom- } \\
\text { me, men ikke overdøde- } \\
\text { lighed) }\end{array}$ & $\begin{array}{l}\text { Klar tendens, men ingen } \\
\text { dosis/respons- } \\
\text { sammenhæng }\end{array}$ & $\begin{array}{l}\text { Sammenhæng bekræftet i } \\
\text { (CEC, 1997:6; CEC \& } \\
\text { DETR, 1999/task 8:16f.). } \\
\text { Her fremhæves også en for- } \\
\text { øget dødelighed }\end{array}$ \\
\hline I & $\begin{array}{l}\text { Lavere niveau af repro- } \\
\text { duktive hormoner (pri- } \\
\text { mært testosteron) }\end{array}$ & $\begin{array}{l}\text { Risiko for lavt } \\
\text { testosteronniveau er 2-4 } \\
\text { gange højere for mænd } \\
\text { med } 2,3,7,8 \text {-TCDD niveau } \\
\text { på over } 20 \text { pg/g }\end{array}$ & \\
\hline II & $\begin{array}{l}\text { Forøget niveau af kole- } \\
\text { sterol og triglycerid (kan } \\
\text { medføre åreforkalkning) }\end{array}$ & $\begin{array}{l}\text { Enkelte undersøgelser ty- } \\
\text { der på sammenhæng, men } \\
\text { dårlig kontrol for evt. an- } \\
\text { dre bagvedliggende årsa- } \\
\text { ger. Nyeste resultater vir- } \\
\text { ker tvivlende. Ingen do- } \\
\text { sis/respons-sammenhæng }\end{array}$ & $\begin{array}{l}\text { Sammenhæng bekræftet i } \\
\text { (CEC, 1997:6) }\end{array}$ \\
\hline II & Diabetes & $\begin{array}{l}\text { For korte og få undersø- } \\
\text { gelser. Ingen do- } \\
\text { sis/respons-sammenhæng }\end{array}$ & $\begin{array}{l}\text { Sammenhæng bekræftet i } \\
\text { (CEC, 1997:6; CEC \& } \\
\text { DETR, 1999/task 8:16f.). } \\
\text { Herunder forøget dødelig- } \\
\text { hed. Dog usikkerhed. }\end{array}$ \\
\hline II & Neurobehaviorale effek- & Tydelig tendens, men in- & Sammenhæng bekræftet i \\
\hline
\end{tabular}

\footnotetext{
${ }^{26}$ Bemærk, at de fleste undersøgelser er lavet ud fra 2,3,7,8-TCDD-niveauer (pg/g fedt) snarere end et bestemt dagligt indtag.
} 


\begin{tabular}{|c|c|c|c|}
\hline & $\begin{array}{l}\text { ter (forsinket motorisk og } \\
\text { intellektuel udvikling) }\end{array}$ & $\begin{array}{l}\text { gen dosis/respons- } \\
\text { sammenhæng. Se evt. } \\
\text { kap.5 }\end{array}$ & $\begin{array}{l}\text { (CEC \& DETR, 1999/task } \\
\text { 8:16f.; Fiedler et al., } \\
\text { 2000:23ff.) }\end{array}$ \\
\hline II & $\begin{array}{l}\text { Endringer i thyroide } \\
\text { hormoner (thymuskirtel) }\end{array}$ & $\begin{array}{l}\text { Ingen longitudinale studi- } \\
\text { er. Ingen dosis/respons- } \\
\text { sammenhæng }\end{array}$ & $\begin{array}{l}\text { Sammenhæng bekræftet i } \\
\text { (CEC \& DETR, 1999/task } \\
\text { 8:16f.; Fiedler et al., } \\
\text { 2000:23ff.) }\end{array}$ \\
\hline III & Kredsløbssygdomme & $\begin{array}{l}\text { Enkelte insignifikante un- } \\
\text { dersøgelser }\end{array}$ & $\begin{array}{l}\text { Sammenhæng bekræftet i } \\
\text { (CEC \& DETR, 1999/task } \\
\text { 8:16f.) }\end{array}$ \\
\hline III & Immunologiske effekter & $\begin{array}{l}\text { Enkelte insignifikante un- } \\
\text { dersøgelser }\end{array}$ & $\begin{array}{l}\text { Sammenhæng nævnt i } \\
\text { (Fiedler, et al., 2000:23ff.) }\end{array}$ \\
\hline III & Forringet sædkvalitet & $\begin{array}{l}\text { Få modstridende undersø- } \\
\text { gelser }\end{array}$ & $\begin{array}{l}\text { Sammenhæng nævnt i } \\
\text { (CEC, 1997:7; Fiedler et al., } \\
\text { 2000:23ff.) }\end{array}$ \\
\hline III & $\begin{array}{l}\text { Endometriose (celler fra } \\
\text { livmoderslimhinden, der } \\
\text { lever uden for livmode- } \\
\text { ren) }\end{array}$ & Undersøgelser på vej. & \\
\hline III & Spontane aborter & $\begin{array}{l}\text { En enkelt undersøgelse } \\
\text { viser tegn på dette, men } \\
\text { der er ikke kontrolleret for } \\
\text { andre evt. bagvedliggende } \\
\text { årsager }\end{array}$ & $\begin{array}{l}\text { Usikkerhed (Fiedler et al., } \\
\text { 2000:23ff.) }\end{array}$ \\
\hline III & Fostermisdannelser & $\begin{array}{l}\text { Enkelte insignifikante un- } \\
\text { dersøgelser }\end{array}$ & Ikke påvist (CEC, 1997:7) \\
\hline III & Tandskader & Undersøgelser på vej & \\
\hline III & $\begin{array}{l}\text { Skæv kønsfordeling } \\
\text { blandt nyfødte }\end{array}$ & $\begin{array}{l}\text { En enkelt undersøgelse } \\
\text { viser tegn på dette, men } \\
\text { der er ikke kontrolleret for } \\
\text { andre evt. bagvedliggende } \\
\text { årsager }\end{array}$ & $\begin{array}{l}\text { Signifikant effekt (CEC \& } \\
\text { DETR, 1999:A6; Fiedler et } \\
\text { al., 2000:23ff.) }\end{array}$ \\
\hline \multicolumn{4}{|c|}{ Akutte symptomer } \\
\hline & Andre hudlidelser & $\begin{array}{l}\text { Forekommer oftest samti- } \\
\text { dig m. klorakne }\end{array}$ & $\begin{array}{l}\text { Nævnt i (Fiedler et al., } \\
\text { 2000:23ff.) }\end{array}$ \\
\hline & $\begin{array}{l}\text { Forøget antal leverenzy- } \\
\text { mer }\end{array}$ & $\begin{array}{l}\text { Få undersøgelser, ingen } \\
\text { dosis/respons- } \\
\text { sammenhæng }\end{array}$ & $\begin{array}{l}\text { Nævnt i (Fiedler et al., } \\
\text { 2000:23ff.) }\end{array}$ \\
\hline & Svagt begrænset lunge- & $\begin{array}{l}\text { Ikke kontrolleret for andre } \\
\text { evt. bagvedliggende årsa- }\end{array}$ & \\
\hline
\end{tabular}




\begin{tabular}{|l|l|l|l|}
\hline & funktion & ger & \\
\hline & Neurologiske ændringer & $\begin{array}{l}\text { Få undersøgelser, ikke } \\
\text { signifikante }\end{array}$ & \\
\hline & Stofskifteproblemer & $\begin{array}{l}\text { Ikke signifikante afvigel- } \\
\text { ser }\end{array}$ & \\
\hline & $\begin{array}{l}\text { Endringer i thyroide } \\
\text { hormoner (thymuskirtel) }\end{array}$ & $\begin{array}{l}\text { Ikke signifikante afvigel- } \\
\text { ser }\end{array}$ & \\
\hline
\end{tabular}

Kilde: CEC, 1997; CEC \& DETR, 1999; US-EPA, 2000: part II, kap.7B, s.108ff.; Fiedler et al., 2000:23ff.

Tabel 8 viser, at antallet af helbredseffekter, der formodes at være relateret til dioxineksponering, er meget stort. Samtidig er det et område, hvor der kontinuerligt forskes intensivt. Der sker derfor løbende en vis afklaring af ovenstående usikkerheder. I det følgende diskuteres de forskellige helbredseffekter med udgangspunkt i både kategoriseringen og konklusionerne fra US-EPA (2000/part II:7b-105ff.).

\subsubsection{Gruppe I - relativt sikre effekter}

Den sygdom - bortset fra kræft - hvis relation til dioxin, der generelt er størst enighed om, er sandsynligvis hudsygdommen klorakne (CEC, 1997:6; CEC \& DETR, 1999/task 8:16f.; Fiedler et al., 2000:23ff.; US-EPA, 2000/part II:7B-108). Symptomerne på denne sygdom har således direkte været anvendt som indikator for, hvorvidt en person har været udsat for dioxin. Klorakne opstår nogle uger eller måneder efter dioxinpåvirkningen, og symptomerne holder som regel op, hvis eksponeringen stopper. Som nævnt er der ikke opstillet en dosis/respons-sammenhæng, men det er påpeget, at Vietnam-veteraner med en dioxinmængde på 4 pg/g i kroppen stort set ikke har udviklet sygdommen (US-EPA, 2000/part II:7B-108). Deraf må det udledes, at påvirkningen skal være højere end dette. De europæiske vurderinger er generelt meget enige i sikkerheden af sammenhængen mellem dioxin og klorakne (CEC, 1997:6; CEC \& DETR, 1999/task 8:16f.; Fiedler et al., 2000:23ff.;).

Dernæst påpeger US-EPA, at der med rimelig sikkerhed kan tales om en risiko for forøget niveau af leverenzymet Gamma Glutamyl Transferase (GGT). GGT-niveauet er interessant, fordi det forøges ved stort set alle leversygdomme. Flere undersøgelser viser, at GGT-niveauet efter nogle år falder tilbage til det normale, hvis dioxineksponeringen ophører. Trods det forøgede niveau af GGT-enzymer er der dog ikke konstateret hverken forøget morbiditet eller mortalitet som følgevirkninger. At dioxiner er skadelige for leveren, er de europæiske rapporter relativt enige med den amerikanske miljøstyrelse om (Fiedler et al., 2000:23). Det fremhæves således også, at dioxiner forårsager skader på parenkymvævet i leveren (CEC, 1997:6). Den nyere europæiske rapport fremhæver i modsætning til den amerikanske, at der er en tendens til forøget mortalitet som følge af leversygdomme, men dette er ikke nærmere uddybet (CEC \& DETR, 1999/task 8:A4).

Den tredje effekt af dioxiner, som er relativt sikker, er et konstateret lavere niveau af reproduktive hormoner, herunder primært det mandlige kønshormon testosteron. I denne forbindelse er der også relativt sikre tegn til et svind i kønskirtlerne som følge af dioxin- 
påvirkning (Fiedler et al., 2000:23). Desuden er der en risiko for andre hormonelle ændringer og skader, primært relateret til binyrebark og skjoldbruskkirtel.

Udover disse symptomer fremhæves det i flere europæiske rapporter, at en omfattende mængde dyreundersøgelser har vist forekomster af vægttab, "tæring" og død ved store mængder dioxin (CEC \& DETR, 1999/task 8:A4; Fiedler et al., 2000:23). Hertil kommer, at dioxin generelt giver anledning til irritation af øjne, slimhinder og kvalme (CEC, 1997:6).

\subsubsection{Gruppe II - potentielle effekter}

Den anden gruppe består af potentielle helbredseffekter, dvs. effekter der er konstateret $\mathrm{i}$ undersøgelser af mennesker, men som kræver flere og bedre undersøgelser. Det skal desuden undersøges, om de her nævnte effekter kun er midlertidige eller kroniske. US-EPA foretager en yderligere opdeling i effekter hos henholdsvis voksne og børn.

Hos voksne er der for det første en risiko for forøgede mængder af kolesterol og triglycerid (et fedtstof). Et forøget niveau af kolesterol og triglycerid kan medføre åreforkalkning og andre helbredseffekter i relation til blodkarene. Denne effekt er også fremhævet i en europæisk undersøgelse (CEC, 1997:6).

For det andet er det omdiskuteret, om der er en forøget risiko for type II diabetes. Her viser dyreforsøg meget forskellige resultater, hvorfor den foreløbige konklusion er, at der ikke er en stærk sammenhæng mellem diabetes og eksponering for 2,3,7,8-TCDD. Denne usikkerhed understreges i de europæiske undersøgelser (CEC, 1997:6). Det er dog et af de områder, hvor der i øjeblikket forskes intensivt. I den europæiske rapport fra 1999 anføres det, at der er tendenser til en højere dødelighed som følge af diabetes (CEC \& DETR, 1999/task 8:A5). En ny undersøgelse af Seveso-ulykken viser en signifikant stigning i antallet af diabetestilfælde hos især kvinder (Bertazzi et al., 2001). Risikoen sættes til 2,4, dvs. $140 \%$ over det almindelige niveau.

Hos børn er det undersøgt, om der er en potentiel forøget risiko for neurobehaviorale effekter, såsom forsinket motorisk og intellektuel udvikling. Pga. manglende kontrol for en række øvrige variable i undersøgelserne, ønsker den amerikanske miljøstyrelse dog ikke at konkludere, om der er tale om sådanne effekter. I modsætning hertil er netop dette område imidlertid i fokus i europæiske studier. Det har således især været diskuteret, om der er en risiko for skadelig indflydelse på f.eks. den kognitive udvikling (CEC \& DETR, 1999/task 8:10). På baggrund af en hollandsk undersøgelse fra 1996 konkluderes følgende: "Exposure to dioxin-like compounds at low dose levels does not cause cancer, but at these intake levels there may be other adverse effects. A great deal of research on the carcinogenic properties and effects on reproduction and prenatal and postnatal development show that developmental effects are the first to be observed as a result of increased exposure" (CEC \& DETR, 1999:task 8:12ff.). Dette gælder også WHO’s seneste anbefaling for dagligt indtag, idet denne alene er fastsat ud fra risikoen for bl.a. forringet sædkvalitet og svækket immunforsvar (CEC \& DETR, 1999/task 8:14). Det anføres i Fiedler et al. (2000:24), at fosteret og den udviklende organisme er over 100 gange mere følsom over for dioxinpåvirkning end den voksne organisme. Det må derfor konkluderes, at en 
række forskere er uenige med den amerikanske miljøstyrelse med hensyn til sikkerheden af sammenhængen mellem neurobehaviorale effekter og et forøget dioxinindtag.

Undersøgelser viser desuden, at der muligvis sker en ændring i de thyroide hormoner. Dette kræver dog også yderligere undersøgelser. I de europæiske rapporter er man mere sikker på denne effekt (CEC \& DETR, 1999/task 8:A4). Det anføres, at dioxin kan give anledning til thymussvind (Fiedler et al., 2000:23).

\subsubsection{Gruppe III - meget usikre effekter}

Endelig gennemgår den amerikanske miljøstyrelse en række helbredseffekter, hvor der er konstateret dosis/respons-sammenhænge hos dyr, men hvor undersøgelser af mennesker er meget usikre.

En enkelt undersøgelse af kemikaliearbejdere i Tyskland viste en overdødelighed som følge af kredsløbssygdomme. Denne overdødelighed var positivt korreleret med mængden af dioxin, som arbejderne havde været udsat for. Desuden viste dyreforsøg tegn på øget tendens til kredsløbssygdomme. Et andet studie af mennesker viste imidlertid ingen speciel overdødelighed af kredsløbssygdomme i relation til dioxin. Problemet har været at kontrollere for øvrige risikofaktorer, såsom rygning, fed mad og manglende motion.

Også studierne af immunologiske effekter ved dioxin har været tvetydige. Dette gælder både undersøgelser af dyr og mennesker. Det anføres derfor i US-EPA, at det er nødvendigt med langt flere undersøgelser, før en sådan sammenhæng evt. kan fastlægges. I Fiedler et al. (2000:23ff.) anføres det til gengæld, at dyreforsøg relativt tydeligt viser faldende modstandsdygtighed over for bakteriologiske angreb samt virus og parasitter. Det samme understreges i CEC (1997:8) og CEC \& DETR (1999/task 8:A4).

Der findes en række undersøgelser, der beskæftiger sig med dioxinernes indflydelse på menneskets reproduktive funktioner. En enkelt undersøgelse tyder på, at der kan ske en forringelse af sædkvaliteten, men dette er dog meget usikkert. Denne helbredseffekt tillægges dog større sikkerhed i de europæiske undersøgelser (CEC, 1997:7; CEC \& DETR, 1999/task 8:A4). Desuden påpeges en tendens til et fald i vægten og størrelsen af de mandlige kønsorganer ved eksponering for dioxin.

Det anføres i US-EPA, at der er en forhøjet risiko for endometriose (skader på livmoderen) hos kvinder, der har været eksponeret for dioxin. Der er en række uddybende undersøgelser på vej. Endvidere er der måske en vis tendens til en forringelse af den kvindelige fertilitet (CEC, 1997:6). Dioxin beskrives således som havende anti-østrogene karakteristika (CEC \& DETR, 1999/task 8:A4).

På baggrund af selvrapportering har der været tegn på, at risikoen for spontan abort er forøget ved dioxineksponering. Problemet er imidlertid, at data vedrørende spontane aborter generelt er meget usikre. Der drages derfor ingen generelle konklusioner vedrørende denne helbredseffekt, om end det anerkendes, at der tilsyneladende er en svag tendens. Også i Fiedler et al. (2000:23ff.) anføres det, at denne effekt er meget usikker.

Det har været fremført, at der måske er en større risiko for fostermisdannelser ved udsættelse for dioxiner. Pga. mangelfulde undersøgelser konkluderer US-EPA imidlertid, at risikoen for denne effekt må betragtes som ukendt. Det samme konkluderes i EU- 
kommissionens rapport (CEC, 1997:7). Heller ikke spørgsmålet om en lavere fødselsvægt hos børn, hvis forældre har været udsat for dioxin, bekræftes i de to rapporter. Lidt mere overbevist er den nyere europæiske rapport, der desuden påpeger andre fosterskader, såsom høreskader (CEC \& DETR, 1999:A5). En enkelt undersøgelse har peget på en vis risiko for tandskader hos spædbørn som følge af dioxinpåvirkning gennem modermælken. Dette er dog meget usikkert.

En effekt, som de fleste studier har hæftet sig ved, er, at dioxineksponering muligvis skaber en skav kønsfordeling blandt nyfødte, således at der fødes relativt flere piger. Selvom undersøgelserne fremhæves, er både US-EPA og de europæiske kilder imidlertid enige om, at en eventuel effekt er usikker (CEC \& DETR, 1999:A6; Fiedler et al., 2000:24).

\subsubsection{Akutte symptomer}

Udover de ovenfor nævnte sygdomme, der potentielt set må betragtes som kroniske, gennemgår den amerikanske miljøstyrelse desuden en række helbredseffekter af mere akut art.

En række forskellige hudlidelser har været observeret som korterevarende effekter hos folk, der har været udsat for dioxin. Effekterne opstår oftest i sammenhæng med klorakne og inkluderer f.eks. hyperpigmentering og cyster på øjenlåget. Dette bekræftes i europæiske rapporter (CEC \& DETR, 1999/task 8:A4). Andre undersøgelser har vist en tendens til et forøget antal leverenzymer, men denne tendens lader dog til at være aftagende, hvis eksponeringen ophører. Tidlige studier viser, at dioxin måske kan forårsage en midlertidig irritation af lungefunktionen og svagt begrænse denne. Helbredseffekten er dog ikke i tilstrækkelig grad kontrolleret for andre risikofaktorer, såsom rygning og alder. Det har været diskuteret, om der måske kunne ske neurologiske aendringer ved udsættelse for dioxiner. Ifølge den amerikanske miljøstyrelse kan longitudinale studier dog ikke bekræfte dette, men som tidligere nævnt er det et område præget af en vis uenighed.

\subsubsection{Opsummering}

Ovenstående gennemgang viser det store antal helbredseffekter, som dioxiner har været fremført som medvirkende årsag til. Samlet set er der derfor ingen tvivl om stoffernes skadelige virkning for mennesker.

Gennemgangen viser imidlertid også den usikkerhed, der er relateret til de mange sygdomme. På baggrund af den amerikanske rapport kan man således kun med relativt stor sikkerhed sige, at dioxineksponering er relateret til kræft, klorakne, et forøget niveau af leverenzymet GGT samt et lavere niveau af især testosteron, Dette komplicerer naturligvis en samlet vurdering af de helbredsmæssige effekter ved dioxin og herunder en samfundsøkonomisk vurdering af disse. Hvis der ikke foreligger dosis/responssammenhænge, er det ikke muligt i en marginalbetragtning at vurdere de samfundsøkonomiske skadesomkostninger, som forbrændingen af et ton affald giver anledning til.

Hertil kommer, at det kun er få af de nævnte helbredseffekter, som det tidligere har været at forsøgt at vurdere skadesomkostningerne ved. F.eks. må det betragtes som meget svært at vurdere de samfundsøkonomiske omkostninger ved et lavere testosteronniveau. Det er 
derfor heller ikke muligt i denne rapport at indregne alle de nævnte sundhedseffekter ved vurderingen af de samfundsøkonomiske sundhedsomkostninger ved affaldsforbrænding.

I det følgende afsnit diskuteres det, hvilke usikkerheder der er forbundet med vurderingen af dioxin samt vurderingen af de forskellige undersøgelser af dioxin.

\subsection{Usikkerheder ved undersøgelserne af dioxiners skadelige helbredseffekter}

Som nævnt er der en lang række usikkerheder knyttet til en vurdering af helbredseffekterne ved dioxin. Hvis der derfor er et ønske om at fastsætte en anbefaling for et maksimalt dagligt indtag, vælges det som regel at indregne en sikkerhedsfaktor. Hermed menes, at det maksimalt anbefalede daglige indtag fastsættes 10-100 gange lavere end det niveau, hvor man ved forsøg har kunnet påvise helbredseffekter (CEC \& DETR, 1999/task 8:10). Efterhånden som sikkerheden af de forskellige sammenhænge imidlertid er steget, er den indregnede sikkerhedsfaktor faldet fra 200 i 1988 (en anbefaling fra Det Nordiske Ministerråd) til WHO's anbefaling fra 1998, der kun indregner en sikkerhedsfaktor på 10 (WHO, 1999:21). Normalt fastsættes en sikkerhedsfaktor på 10 for "intraspecies variability" og en sikkerhedsfaktor på 10 for "interspecies variability". Førstnævnte tager højde for, at følsomheden og optagelsen af et stof varierer inden for en bestemt art (såsom mennesket) pga. f.eks. alder, køn, helbred m.v. Sidstnævnte sikkerhedsfaktor tager højde for, at følsomheden varierer mellem arter (såsom mellem forsøgsdyr og mennesker). I alt regnes således normalt med en sikkerhedsfaktor på 100 (CEC \& DETR, 1999/task 8:11; Fiedler et al., 2000:27). I de amerikanske undersøgelser opstilles ingen tærskelværdi, da det antages, at denne enten er noget lavere end det aktuelle niveau for indtagelse eller ikke-eksisterende (Holland et al., 1999:186).

I det følgende nævnes nogle usikkerheder ved antagelserne om en sammenhæng mellem dioxiner og helbredseffekterne. Disse usikkerheder kan opdeles på flere forskellige typer.

For det første er det naturligvis ikke etisk acceptabelt at foretage kontrollerede forsøg med mennesker ved at udsætte disse for dioxin. Derfor baseres en meget stor del af konklusionerne vedrørende menneskelige helbredseffekter på dyreforsøg, hvorefter undersøgelsesresultaterne ekstrapoleres til mennesker. De fleste forskere betragter det som påvist i acceptabel grad, at celler og væv fra henholdsvis dyr og mennesker reagerer relativt ens over for dioxiner (US-EPA, 2000:16). Det er derfor nogenlunde acceptabelt at overføre resultater. Andre forskere påpeger imidlertid, at f.eks. forskellige typer mus reagerer meget forskelligt, hvorfor sammenligningen med menneskelige reaktionsmønstre bør være noget mere forsigtig (CEC, 1997:5). En kilde rapporterer således, at den dødelige dosis af dioxiner er over 5000 gange større hos hamstere end hos marsvin (Fiedler et al., 2000:23). I WHO's anbefalede daglige maksimumsindtag er der ikke indregnet den nævnte "interspecies" sikkerhedsfaktor, idet man har ment, at reaktionsmønstrene hos dyr og mennesker i forbindelse med dioxinpåvirkning er påvist at være tilstrækkeligt ens (WHO, 1999:21). Der er derfor kun anvendt en sikkerhedsfaktor på 10.

For det andet har data fra forskellige udslipsulykker, såsom Seveso, været anvendt til at undersøge effekten af dioxiner på mennesker. Problemet er i denne sammenhæng, at man 
hermed foretager en ekstrapolation af helbredseffekterne fra højdosisemissioner til helbredseffekter ved lavdosisemissioner. Det betragter flere forskere som meget uheldigt (Larsen, Fødevaredirektoratet). Desuden er de anvendte blodprøver af de eksponerede personer indsamlet op til årtier efter den sidste eksponering (US-EPA, 2000:part II, kap.8). Det skaber en høj grad af usikkerhed.

For det tredje er det problematisk at opstille dosis/respons-sammenhænge for mennesker generelt, idet det formodes, at der stor forskel på reaktionsmønstre mellem f.eks. børn og voksne samt kvinder og mænd (CEC, 1997:6; US-EPA, 2000:22). Ved WHO's fastsatte værdi for maksimalt dagligt indtag er der derfor indregnet en sikkerhedsfaktor på 10 for at tage højde for forskellige menneskers forskellige reaktionsmønstre. De fleste resultater er i øvrigt fremkommet på baggrund af undersøgelser af mænd. Det er derfor vanskeligt at vide, om kvinder reagerer analogt med mænd ved dioxineksponering.

For det fjerde er det problematisk i forhold til en vurdering af den direkte sammenhæng mellem dioxin og helbredsskader, at der oftest er tale om langtidseffekter. I flere projekter undersøger man endog helbredsskaderne på afkommet hos hundyr, der har været eksponeret for dioxin. Pga. den lange tidshorisont er det meget svært at kontrollere for andre påvirkninger, såsom tobaksrygning, hvorved det er problematisk at påpege en direkte sammenhæng mellem dioxin og helbredseffekter (US-EPA, 2000:part II, kap.8). Hertil kommer, at det varierer, om de forskellige undersøgelser har indregnet et generelt "baggrundsindtag" af dioxin og i så fald størrelsen på dette.

For det femte er det nødvendigt at foretage en lang række antagelser vedrørende f.eks. mængden af fedt i kroppen, halveringstiden for dioxiner o.s.v., der alle har stor betydning for beregningerne. Disse antagelser varierer desuden fra undersøgelse til undersøgelse, hvilket komplicerer en sammenligning.

\subsection{Opsummering}

I dette kapitel er der gennemgået en lang række effekter på helbredet, som dioxiner har været fremført som medvirkende årsag til. På baggrund af de mange undersøgelser må det konkluderes, at der er en meget stor sandsynlighed for, at dioxin har en skadelig effekt på det menneskelige helbred. Til gengæld må det også konkluderes, at der eksisterer en udbredt usikkerhed vedrørende den præcise sammenhæng mellem dioxineksponeringen og de enkelte sygdomme. Med udgangspunkt i rapporten fra den amerikanske miljøstyrelse blev det fastslået, at der er størst sandsynlighed for en sammenhæng mellem dioxineksponering og kræft, klorakne, et forøget niveau af leverenzymet GGT samt et lavere niveau af især testosteron. Problemet var imidlertid yderligere, at der kun findes en dosis/responsmodel for sammenhængen mellem dioxineksponering og kræftdødsfald. Den overordnede konklusion blev derfor, at det i denne rapport ikke er muligt at inddrage de mange nævnte morbiditetseffekter men alene mortalitetseffekterne som følge af kræft. Omkostningsopgørelsen over de skadelige eksternaliteter ved dioxin vil derfor alene inkludere mortalitetseffekter relateret til kræft.

Herefter blev det diskuteret, hvad der er årsag til den store usikkerhed på området. Fem væsentlige faktorer blev nævnt i denne sammenhæng. For det første er flere af helbredseffekterne konstateret ved dyreforsøg, hvorfor det kan diskuteres, i hvor høj grad disse kan 
anvendes til at sige noget om effekter på mennesker. For det andet kan det kritiseres, at flere af helbredseffekterne er konstateret i forbindelse med en meget høj dosis, hvorefter man - idet der antages en lineær sammenhæng mellem indtag og effekt - drager konklusioner vedrørende de meget lavere doser, der er relevante for størstedelen af befolkningen. Hertil kommer, at de fleste af disse højdosiseffekter vedrører mænd, hvorfor det er usikkert, om tilsvarende sammenhænge gør sig gældende for kvinder og børn. Endvidere optræder effekter af dioxin (såsom kræft) som oftest først lang tid efter eksponeringen, hvilket også bidrager til usikkerheden, idet de pågældende personer må formodes at have været eksponeret for mange andre mulige risikofaktorer. Endelig kræver opstillingen af dosis/respons-modeller, at der opstilles en række antagelser vedrørende bl.a. kropsvægt, fedtmasse, halveringstider etc. Dette kan også bidrage til usikkerheden.

Samlet set må det dog konkluderes, at der er et rimeligt videnskabeligt belæg for at lave et tentativt regneeksempel på skadesomkostningerne for de negative eksternaliteter ved affaldsforbrænding på baggrund af den dosis/respons-model for kræftdødsfald, som er opstillet af den amerikanske miljøstyrelse. Dette vil derfor være formålet med næste kapitel. 


\section{Regneeksempel: Dioxin- relaterede helbredsomkostninger}

\subsection{Indledning}

I dette kapitel vil der blive udarbejdet en tentativ prissætning af de sundhedsmæssige effekter, som dioxinudledningen ved affaldsforbrænding medfører i Danmark. Det er meget vigtigt at understrege, at dette skal betragtes som et studie $\mathrm{i}$ beregningsmetoden snarere end som et forsøg på at fastlægge en eksakt værdi for helbredseffekterne af dioxin. Da hvert led i beregningen er forbundet med en meget høj grad af usikkerhed, må det endelige estimat kun tolkes som et usikkert skøn.

Nedenstående syv variable er nødvendige for den endelige beregning:

- Danskernes årlige gennemsnitsindtag af dioxin fra fødevarer

- Andelen af dioxin, der stammer fra dansk producerede fødevarer

- Den samlede årlige dioxinmængde tilført det danske areal, der producerer fødevarer

- Andelen af danske emissioner, der ender på dansk territorium

- Affaldsemissionskoefficienten, dvs. udledningen af dioxin pr. ton forbrændt affald

- Dosis/respons-funktionen (opgjort pr. år.)

- Prissætning af et dødsfald

I det følgende afsnit 2 gennemgås disse variable, idet der angives et forsigtigt estimat. Det diskuteres desuden, hvilke eventuelle usikkerheder der skal danne baggrund for den senere følsomhedsanalyse. I afsnit 3 kobles disse tal til et samlet omkostningsestimat. For overskuelighedens skyld er det valgt at fremstille beregningen samlet efter præsentationen af de enkelte variable. Endelig foretages i afsnit 4 en følsomhedsanalyse, hvor det vurderes, hvor meget det endelige omkostningsestimat vil variere, når de enkelte parametre varierer.

\subsection{Gennemgang af variable}

\subsubsection{Danskernes årlige gennemsnitsindtag af dioxin fra fødevarer}

Af tabel 6 fremgik det, at det gennemsnitlige dioxinindtag i Danmark via føden er ca. 1,7 TEQ picogram $/ \mathrm{kg}$. kropsvægt/dag. Da det menneskelige dioxinindtag via luften er meget 
begrænset, er dette ladt ude af analysen. De væsentligste faktorer med betydning for dette estimat er sammensætningen af føden. Det har f.eks. stor betydning, hvor stor en del af føden, der består af fisk. Hvis en persons kødindtag således kun består af vilde fisk, der indeholder meget dioxin, stiger det daglige indtag til 7,2 picogram TEQ $/ \mathrm{kg}$. kropsvægt/dag. ${ }^{27}$ Består hele en persons kødindtag imidlertid af svinekød (der er målt til at have den laveste mængde dioxin pr. g fedt,) falder dioxinindtaget til 0,78 picogram TEQ/kg. kropsvægt/dag. ${ }^{28}$ I den afsluttende følsomhedsanalyse inkluderes derfor et interval på 0,8 - 7,2 picogram. En anden meget væsentlig usikkerhedsfaktor i denne forbindelse er, at spædbørn som nævnt kan risikere at indtage en meget større daglig dosis via modermælken. Dette inddrages dog ikke yderligere i denne beregning.

\subsubsection{Andel af dioxin, der stammer fra dansk producerede fødevarer}

En stor del af de fødevarer, der indtages i Danmark, er ikke produceret i Danmark. Derfor er det ikke rimeligt at betragte al den dioxin, der i Danmark indtages via føden, som potentielt set stammende fra den danske affaldsforbrænding. Det er således nødvendigt at undersøge, hvor stor en del af de fødevarer, der indtages i Danmark, der er produceret i Danmark. Dette kan imidlertid kun blive et meget groft overslag, da blandt andre en af de mest grundige analyser af dioxin i Danmark ikke er gået ind i spørgsmålet om import og eksport (COWI, 2000:41).

Der findes ingen fuldstændigt opdaterede opgørelser over andelen af dansk producerede fødevarer, der indtages Danmark. Danmarks Statistik oplyser, at det private konsum af animalske og vegetabilske produkter i 1990 var i alt ca. 5,3 mio. tons (Gravgaard, 2002). Heraf var 0,75 mio. tons (14\%) direkte import. Opgjort i kroner var det samlede private konsum af fødevarer i 1998 på 64,8 mia. DKK (køberpris), hvoraf 8,6, mia. DKK var import (13\%). Disse tal er lidt problematiske af flere årsager. Dels dækker konsumbegrebet lidt bredere end fødevarer, idet husholdningerne ikke spiser alle indkøbte vegetabilske og animalske produkter. Desuden mangler der i opgørelsen den mængde forarbejdede importerede råvarer, som købes af husholdningerne, idet disse regnes som dansk producerede. Endelig er tallene (i fysiske størrelser) 12 år gamle. Alt i alt kan det dog ikke betragtes som misvisende at regne med, at ca. $86 \%$ af de fødevarer, der indtages i Danmark, også er dansk producerede.

Det kan diskuteres, hvilken betydning det har for dioxinniveauet, om det anvendte dyrefoder er produceret i Danmark eller i udlandet. Selvom en ko er opvokset og slagtet i Danmark, kan den ikke have optaget affaldsforbrændingens dioxinnedfald, hvis den alene er fodret med udenlandsk foder. Hvis det samlede foderforbrug opgøres i indholdet af fordøjeligt råprotein, udgør den dansk producerede andel $58 \%$ ud af det samlede foderforbrug på 2457 mio. kg. Opgøres tallet i stedet i foderværdi er den dansk producerede andel 74\% (Danmarks Statistik, 2002:60). Det er derfor en ikke ubetydelig del af foderet, der er importeret. Til gengæld må det antages, at kun en meget begrænset del af de dansk

\footnotetext{
${ }^{27}$ Det antages her, at en person indtager $153 \mathrm{~g} \mathrm{kød/fisk} \mathrm{pr.} \mathrm{dag} \mathrm{(Fødevaredirektoratet/Plantedirektoratet,} \mathrm{2001:25).}$

${ }^{28}$ Anvendes i stedet estimerede værdier indeholder oksekød dog mindst dioxin.
} 
producerede dyr alene lever af udenlandsk foder. Derfor inddrages spørgsmålet om foderets oprindelsessted ikke i beregningen.

Til gengæld betyder dels usikkerheden vedrørende selve beregningen af importdelen af de danske fødevarer og dels ovenstående usikkerhed vedrørende foderets oprindelsessted, at estimatet på $86 \%$ må betragtes som usikkert og derfor forsøges varieret $i$ en følsomhedsanalyse.

\subsubsection{Den årlige dioxinmængde, der tilføres det danske fødevareproducerende areal}

For at kunne estimere betydningen af det dioxin, der udledes via affaldsforbrændingen, er det nødvendigt at opstille nogle antagelser vedrørende spredningen og nedfald (deposition) af dioxin. For det første antages det, at størstedelen af den dioxin, der findes i og på jorden, er resultatet af nedfald fra luften. Af Miljøstyrelsens rapport (COWI, 2000:8) fremgår det, at jorden også modtager dioxin fra biomasse, bålafbrænding og husdyrgødning. Også en ny svensk rapport konkluderer, at størstedelen af dioxinudledning til fødevarerne stammer fra kompostering (Ahlgren \& Marklund, 2002). Det fastslås dog i Miljøstyrelsens rapport fra 2000, at det er acceptabelt at antage, at langt den væsentligste del af dioxinen i jorden stammer fra nedfald (COWI, 2000:41). Det antages derfor, at al dioxin, der ligger på jorden, stammer fra nedfald fra luften.

For det andet er det nødvendigt at antage, at det dioxin fra affaldsforbrænding, der falder på landbrugsjorden og i vandet, indgår i det økologiske kredsløb og dermed i de fødevarer, der produceres, $\mathrm{i}$ samme forhold som dioxinnedfaldet fra andre emissionskilder. ${ }^{29}$ Dette er naturligvis også en grov forsimpling, idet det pga. spredningsveje må formodes at variere en del rent geografisk, hvor dioxinen falder. Antagelsen indeholder derfor en relativt stor potentiel fejlkilde.

For det tredje er det nødvendigt at antage, at dioxinnedfaldet spredes fuldstændigt jævnt over alle typer jord og vand inden for Danmarks grænser. Herved kan det beregnes, hvor stor en andel af det samlede areal, der indgår i produktion af fødevarer. Det danske areal (inkl. søer) er ca. $44.000 \mathrm{~km}^{2}$, mens det danske havareal er ca. $106.000 \mathrm{~km}^{2}$ (Alexandersen, Kort og Matrikelstyrelsen). I alt spredes dioxinen derfor over et areal på ca. 149.100 $\mathrm{km}^{2}$. Landbrugsjorden i Danmark udgør ca. $26.720 \mathrm{~km}^{2}$. Desuden antages det, at de fisk, som vi spiser, bevæger sig og indtager føde over hele havarealet.

Der findes ingen præcise opgørelser over depositionen af dioxin på det danske areal. I en statusrapport over forsøg ved bl.a. Fredensborg fra 2003, anføres det, at en deposition på 75 g WHO-TEQ/år over Danmarks landareal $\left(44.000 \mathrm{~km}^{2}\right.$ ) er et rimeligt skøn (Vikelsøe, 2003). ${ }^{30}$ Med samme tilførsel pr. $\mathrm{km}^{2}$ må tilførslen til det fødevareproducerende areal (landbrugsareal og hav) udgøre:

\footnotetext{
${ }^{29}$ Det er relevant at overveje, at anlæggene til affaldsforbrænding ofte ligger tæt på de større byer. Derfor kan man argumentere for, at disse byboere er overeksponerede. Fordi befolkningen imidlertid primært udsættes for dioxin via fødevarerne, og disse produceres over hele landet, forventes dette dog ikke at have den store betydning.

${ }^{30}$ Som nævnt sættes WHO-TEQ lig TEQ i nærværende undersøgelse.
} 
$\left(75 \mathrm{~g}: 44.000 \mathrm{~km}^{2}\right) \cdot\left(26.720 \mathrm{~km}^{2}+106.000 \mathrm{~km}^{2}\right)=226,23 \mathrm{~g}$ TEQ

Der tilføres således 226,23 g TEQ dioxin årligt til danske arealer, der producerer fødevarer.

Antagelsen er noget problematisk. F.eks. findes der ingen undersøgelser af, hvor meget dioxin der falder over vandet, men det er tidligere antaget, at nedfaldsmængden er begrænset i forhold til det nedfald, der sker over landjorden (COWI, 2000:94). Samtidig er det forsimplet at antage, at fisk bevæger sig og indtager føde over hele det danske havareal. Hvis vi imidlertid alternativt havde valgt at udelade dioxinnedfaldet over vand, ville det medføre, at dioxinindtaget fra fisk også måtte udelades. Dette ville have givet anledning til en måske endnu større fejlkilde, fordi dioxinbidraget fra fisk er meget væsentligt for det samlede indtag via fødevarer (se tabel 7). Derfor er antagelsen nødvendig.

Samtidig er det imidlertid også rimeligt at inddrage et følsomhedsinterval for dette estimat i den afsluttende følsomhedsanalyse. Denne skal bl.a. tage højde for, at depositionen er forskellig fra egn til egn. Det er angivet i en ny publikation fra COWI og Miljøstyrelsen, at det er rimeligt at anvende et usikkerhedsinterval svarende til +/- faktor 2 (COWI, 2003:97). Publikationen angiver et interval på 13-130 g I-TEQ/år. Dette anvendes, selvom det ikke nøjagtigt svarer til +/- faktor 2 for det opgivne punktestimat på $75 \mathrm{~g} \mathrm{WHO-}$ TEQ/år.

\subsubsection{Andelen af danske emissioner, der ender på dansk territorium}

Det er endvidere nødvendigt at overveje, hvilken andel af de danske emissioner der ender på dansk territorium. Problemet er, at der forekommer både en import og eksport af dioxiner via luften (COWI, 2000: 94). Vi importerer ufrivilligt en mængde dioxin via luften fra bl.a. Tyskland, Belgien og England. Til gengæld vil en del af den dioxin, der udledes i Danmark, blive eksporteret til bl.a. Sverige. Da vi ikke har data for den respektive import eller eksport af dioxin via luften, må det antages, at disse to flows balancerer. Det antages således, at hele den danske emissionsmængde af dioxin ender på dansk territorium.

Da vi ikke har kendskab til, hvor stor usikkerheden er i forbindelse med dette estimat, er det nødvendigt at lave en følsomhedsanalyse, hvor estimatet forsøgsvis varieres.

\subsubsection{Affaldsemissionskoefficienten}

Ved begrebet affaldsemissionskoefficienten forstås udledningen af dioxin pr. ton forbrændt affald. I Danmark forbrændes ca. 2,9 millioner tons affald pr. år (COWI, 2003:84). En stor del af den dioxin, der dannes i denne forbindelse, bindes imidlertid i restprodukter, såsom slagger, der deponeres. Det anslås, at affaldsforbrændingen giver anledning til en emission til luften på ca. 15,7 g I-TEQ/år, idet der dog er opstillet et usikkerhedsinterval på 6,4 til 28,9 g I-TEQ/år. Dette svarer til en udledningskoefficient på 5,41 mikrogram I-TEQ pr. ton affald. Affaldsforbrændingens dioxinemission til vand og jord er stort set ikke målbar. Udledningskoefficienten opgives ofte i mængden af dioxin i nanogram pr. udledt kubikmeter røggas. Hvis det antages, at der dannes ca. $6500 \mathrm{~m}^{3}$ røg- 
gas pr. ton affald, kan udledningskoefficienten omregnes til 0,0008 mikrogram I-TEQ pr. $\mathrm{m}^{3}$ røggas, dvs. 0,83 nanogram pr. $\mathrm{m}^{3}$ røggas (COWI, 2003).

Der er imidlertid flere problemer ved dette estimat. For det første afhænger udledningskoefficienten af forbrændingsanlæggets tekniske karakteristika, der er forbundet med anlæggets alder og de krav og standarder, der vedrører forbrændingen. Blandt disse kan nævnes forbrændingstemperatur, filtre, skorstenshøjde etc. Flere repræsentanter for affaldssektoren fremfører, at de fleste eksisterende anlæg udleder ca. 1,0 nanogram $/ \mathrm{m}^{3}$ (ca. lig 6,5 mikrogram pr. ton affald), men at dette reduceres til ca. 0,1 nanogram $/ \mathrm{m}^{3}$ (ca. 0,65 mikrogram dioxin pr. ton affald), hvis der monteres et dioxinfilter. Ved beregningen af værdien på 15,7 g dioxin pr. år er der taget højde for, at nogle anlæg har monteret et sådant filter, mens andre endnu ikke har (COWI, 2003).

Årsagen er, at det europæiske affaldsdirektiv fra 2000 fastsætter den maksimale udledning af dioxin til 0,1 nanogram I-TEQ $/ \mathrm{m}^{3}$, dvs. PCB udelades (L 332/91). ${ }^{31}$ For eksisterende anlæg skal bestemmelserne i direktivet tillempes fra og med 28. december 2005, og for nye anlæg fra og med 28. december 2002. Ifølge $\S 1$ er et af målene med affaldsdirektivet at reducere dioxinemissionen fra identificerede kilder med 90\% i forhold til 1985niveauet inden år $2005 .{ }^{32}$ Det må derfor forventes, at flere anlæg vil montere filtre for at imødekomme kravet inden år 2005. I Danmark er det hensigten, at bestående forbrændingsanlæg skal overholde dioxingrænsen på $0,1 \mathrm{ng} / \mathrm{m}^{3}$ senest 28 . december 2004 , dvs. 1 år før fristen i direktivet. For anlæg, der om- eller udbygges til erstatning for eksisterende ovnlinjer, der tages ud af drift, accepteres dog en frist til 28. december 2005 for at undgå ophobning af affald (Hansen, 2002).

For det andet er den udledte dioxinmængde afhængig af, hvilken affaldstype der forbrændes. Som det fremgik af kapitel 2, viser en norsk undersøgelse, at mens forbrændingen af et ton metal eller glas ikke giver anledning til dioxinudledning, så sker der en emission til luften på 2-3 mikrogram I-TEQ ved forbrænding af et ton vådt organisk affald eller tekstil, ca. 7 mikrogram pr. ton forbrændt papir, plast eller træ og op til 14-15 mikrogram pr. ton forbrændt restaffald eller blandet husholdningsaffald (ECON, 2000:15). Disse værdier stammer dog fra en amerikansk undersøgelse fra 1991.

For det tredje har det betydning for udledningskoefficienten, hvor ofte der måles. Jo oftere der måles, jo bedre estimat må der opnås, idet unormale udsving (outliers) kan frasorteres. For det fjerde - og i relation til førnævnte punkt - er udledningen af dioxin ikke konstant

\footnotetext{
${ }^{31}$ I affaldsdirektivets $§ 2$ hedder det: Protokollen om persistente organiske forurenende stoffer, som Fællesskabet har underskrevet i forbindelse med De Forenede Nationers Økonomiske Kommission for Europas (UNECE's) konvention om grænseoverskridende luftforurening over store afstande, fastsætter retligt bindende grænseværdier for dioxin- og furanemissioner på $0,1 \mathrm{ng} / \mathrm{m}^{3} \mathrm{Gæ}$ (giftækvivalent) for forbrændingsanlæg, der forbrænder over 3 tons fast husholdningsaffald i timen, $0,5 \mathrm{ng} / \mathrm{m}^{3} \mathrm{Gæ}$ for anlæg, der forbrænder over 1 ton sygehusaffald i timen og $0,2 \mathrm{ng} / \mathrm{m}^{3} \mathrm{Gæ}$ for anlæg, som forbrænder over 1 ton farligt affald i timen”. Der fastlægges dermed en grænseværdi på 0,1 nanogram dioxin $/ \mathrm{m}^{3}$ (Europaparlamentets og Rådets direktiv 2000/76/EF af 4. december 2000 om forbrænding af affald). Se http://europa.eu.int/eur-lex/pri/da/oj/dat/2000/1_332/1_33220001228da00910111.pdf

${ }^{32}$ Selvom Norge ikke er med i EU, forventes landet alligevel at implementere disse emissionsgrænser (ECON, 2001:11).
} 
men varierende i forhold til forbrændingsprocessen. Da dioxinmængden bl.a. afhænger af temperaturen ved forbrændingen, dannes der mere dioxin, når anlægget slukkes og tændes.

For det femte er den dosis/respons-sammenhæng, der senere skal anvendes i regneeksemplet, angivet i måleenheden TEQ, hvorfor udledningsmængden også bør være i TEQ.

Denne betegnelse inkluderer dels PCB'er og har andre måleforhold for visse dioxiner og furaner. Dette er muligt at opgøre for den samlede deposition (se ovenfor), men ikke for udledningen ved affaldsforbrændingen. Derfor er det nødvendigt at overveje, om affaldsforbrændingens udledning af TEQ svarer til udledningen i I-TEQ. Dette findes der ingen danske data for. Det betragtes imidlertid som relativt acceptabelt at antage, at udledningsandelen er stort set den samme i måleenheden TEQ som i måleenheden I-TEQ (Vikelsøe, 2002a; 2002b).

Samlet set kan de reelle værdier for udledningskoefficienten derfor variere markant fra den ovenstående værdi. Følsomhedsintervallet for denne variabel sættes til 6,4 til 28,9 g på baggrund af de nyeste udledningsopgørelser (COWI, 2003:85).

\subsubsection{Dosis/respons-funktionen for kræftdødsfald}

I denne undersøgelse vil vi som nævnt alene betragte mortalitetseffekterne af dioxinerne, idet morbiditetseffekterne ikke må betragtes som tilstrækkeligt belyste. Der anvendes den dosis/respons-funktion for dødelige kræfttilfælde som følge af dioxinindtag, der er udregnet i rapporten fra den amerikanske miljøstyrelse. Da risikovurderingen antages at gælde både baggrundsniveau og yderligere indtag over dette niveau (en marginalbetragtning), kan den bruges i dette tilfælde. Som nævnt er risikoen sat til $1 \cdot 10^{-3}$ risiko/picogram TEQ/kg. kropsvægt pr. dag (US-EPA, 2000/part III:97). Dette betyder, at risikoen for at dø af kræft stiger med 0,001 , når den daglige dioxineksponering stiger med 1 picogram TEQ pr. kg. kropsvægt. ${ }^{33}$ Det antages, at dette indtag sker hele livet igennem. Blandt 1000 eksponerede vil der således gennemsnitligt set være én mere, der dør af kræft, når den gennemsnitlige eksponering stiger med 1 picogram TEQ pr. kg. kropsvægt pr. dag.

Dosis/respons-modellen er et udtryk for, at fødes 1.000 personer på samme tid, vil én af dem i løbet af de næste 77 år (deres forventede levetid) få kræft og dø som følge af at have indtaget 1 picogram dioxin $/ \mathrm{kg}$. kropsvægt/dag hele livet igennem. ${ }^{34}$ For at dette skal resultere i ét kræfttilfælde om året, er man nødt til at antage en ligevægtsbefolkning på 77.000 personer (der fødes og dør hvert år 1.000 personer) med 1.000 personer i hver al-

\footnotetext{
${ }^{33}$ Som nævnt er der anvendt "upper bound cancer risk", dvs. den højst mulige risiko.

${ }^{34}$ Den danske middellevetid var i 2000 74,3 år for mænd og 79,0 år for kvinder (Sundhedsnyt, 2001). Det giver et gennemsnit på 76,65 år. I USA angives den gennemsnitlige levetid i 2000 at være 76,9 år (http://www.cdc.gov/nchs/fastats/lifexpec.htm). Det betragtes derfor som rimeligt at overføre tallene fra USA til Danmark.
} 
dersgruppe. ${ }^{35}$ Dette kan dermed senere sættes i forhold til det faktiske befolkningsantal i Danmark og benyttes i regneeksemplet.

Det europæiske forskningsprojekt vedrørende værdisætning af eksternaliteter ved energiproduktion - ExternE - angiver, at mål for livstidsrisiko kan omregnes til årlig risiko ved at dividere med den gennemsnitlige levetid i det pågældende land (Holland et al., 1999:186). Dette er også anvendt i andre undersøgelser (Rabl, Spadaro \& McGavran, 1998:17). Anvendes dette på den pågældende dosis/respons-model, må det formodes, at hvis $1 \mathrm{ud}$ af 1000 dør som følge af dioxin over et helt liv, vil $13 \mathrm{ud}$ af 1.000 .000 mennesker dø om året $\left(1,299 \cdot 10^{-5}\right)$, hvis der antages en gennemsnitslevealder på 77 år. Problemet er bl.a., at befolkningssammensætningen i Danmark ikke er så jævnt fordelt over aldersgrupper, som det antages ovenfor. Det er derfor svært at sige noget om den reelle udvikling i kræfttilfælde.

Udover dette problem er der yderligere to komplikationer ved at anvende den amerikanske dosis/respons-model. På den ene side - og i relation til ovenstående - er risikoen for at dø af kræft som følge af dioxin sandsynligvis aldersrelateret, således at risikoen forøges med alderen. Bruce Rodan, der er medforfatter af US-EPA 2000, har således udtalt følgende til spørgsmålet om, hvorvidt sammenhængen er afhængig af alder: "Yes, but we don't know exactly how. If you assume dioxin is a cancer promoter, then presumably the effects would be more evident as age progresses following more initiation events, but this is just supposition ... I don't know how you can quantify this" (Rodan, 2002). Denne interaktion mellem risiko og alder inddrages således ikke $\mathrm{i}$ analysen, men giver anledning til en væsentlig fejlkilde.

På den anden side er der som nævnt kun opstillet en dosis/respons-model for TEQværdien, dvs. inklusive dioxinlignende PCB'er. Dette er problematisk, fordi de danske udledningsværdier kun foreligger i måleenheden I-TEQ. Som tidligere nævnt er det derfor nødvendigt at antage, at udledningsforholdet af dioxin er ens for de to måleenheder.

I det afsluttende følsomhedsanalyse inkluderes derfor et interval med en risiko på 0,00013 $-0,0000013$.

\subsubsection{Prissætning af et dødsfald}

Som det fremgik af afsnit 2.3 har valget, af hvordan et dødsfald skal værdisættes, stor betydning for resultatet af cost/benefit-analyser. Værdisætning af dødsfald er et omdiskuteret emne inden for cost/benefit-analyser, og der er blevet anvendt flere forskellige tilgange til spørgsmålet. Traditionelt skelnes mellem to tilgange, nemlig værdisætning baseret på faktiske omkostninger og værdisætning baseret på betalingsvillighed. Ved en omkostningsbaseret tilgang værdisættes et dødsfald ud fra de økonomiske tab, som samfundet påføres ved et dødsfald. Dette inkluderer f.eks. tab af produktion og forbrug. Som eksem-

\footnotetext{
${ }^{35}$ Dette er ikke helt korrekt, for når én ud af 1.000 pludselig dør i løbet af 77 år, er gennemsnitslevealderen ikke længere helt 77 år; men denne unøjagtighed er så lille, at vi vælger at se bort fra den.
} 
pel på denne metode kan nævnes Vejdirektoratets enhedspriser for trafikuheld. ${ }^{36}$ Metoden er dog blevet kraftigt kritiseret for ikke i tilstrækkelig grad at inddrage det immaterielle velfærdstab ved et dødsfald, hvorfor den anvendes i stadig mindre grad.

Metoden baseret på betalingsvillighed opgør individers villighed til at betale for enten at reducere risici for en for tidlig død eller individets vurdering af hvilken kompensation, der bør gives, for at sådanne konsekvenser bliver "acceptable". Værdien af et "statistisk liv" (VSL) udledes således som individernes samlede betalingsvillighed for en reduktion af dødsrisikoen, som indebærer, at én person mere statistisk set overlever. Problemet ved denne metode er, hvordan befolkningens betalingsvillighed afdækkes på en valid og troværdig måde. Det er således omdiskuteret i hvilken grad det er muligt at overføre estimater for VSL fra et geografisk område, tidspunkt eller politikområde til et andet (anvende såkaldt benefit transfer). Trods disse uenigheder, anbefales tilgangen af bl.a. EU og vil således også være baggrunden for nærværende analyse (Holland \& Watkiss, 2002). Nyere referencer på området angiver ofte to forskellige VSL for hhv. trafikuheld og luftforurening (WHO, 1999). Årsagen til forskellen er, at gennemsnitsalderen ved trafikuheld er fra 30 til 40 år, mens gennemsnitsalderen for dødsfald relateret til luftforurening er 75 til 85 år. Samtidig er det sandsynliggjort, at betalingsvilligheden for et statistisk liv som funktion af alder udgør en omvendt U-kurve. VSL ved luftforurening er således blevet sat til ca. $61 \%$ af VSL ved et trafikuheld.

I denne sammenhæng er det usikkert, hvornår dødsfald som følge af et vist dioxinindtag vil indtræde. Da det som nævnt ofte er et spørgsmål om, at dioxinen oplagres i kroppen over en længere periode, må det betragtes som sandsynligt, at tidspunktet for dødsfald ligger tættere på 75-85 år end på 30-40 år (Rodan, 2002; CEC, 1997:7). Derfor anvendes VSL for luftforurening (kronisk).

I nogle undersøgelser argumenteres der for, at man burde værdisætte et dødsfald som antallet af tabte livsår snarere end ved een fast værdi (VOLY-tilgangen). Dette blev bl.a. anvendt i det europæiske ExternE-projekt (Holland et al., 1999). Tendensen går dog i retning af at fastholde VSL-tilgangen, hvilket også vil være tilfældet her. I relation hertil skelnes ofte mellem akut og kronisk mortalitet, hvor førstnævnte relateres til dødsfald, der sker dage eller uger efter påvirkningen, mens sidstnævnte relateres til dødsfald, der sker måneder eller år efter påvirkningen. Her er det valgt at anvende værdien for et kronisk dødsfald.

Den seneste undersøgelse på området - det europæiske BeTa-projekt - anvender værdien 1 million euro for et akut dødsfald forårsaget af luftforurening og 490.000 euro for et kronisk dødsfald, hvor der statistisk set mistes 5 livsår. Sidstnævnte svarer - korrigeret for inflation, købekraft mv. - til 5,3 millioner danske kroner i 2002 (Andersen, 2003). Værdien er yderligere korrigeret for diskonteringsrenten. I BeTa anvendes en diskonteringsrente på 4\%, mens det i Miljø- og Energiministeriets vejledning anbefales at anvende en diskonteringsrente på 3\%, hvorfor dette er anvendt i rapporten (Møller et al. 2000).

\footnotetext{
${ }^{36}$ Vejdirektoratet anvender dog ikke en "ren" omkostningstilgang, idet et dødsfald tillægges et velfærdstab på 200\% af de faktiske omkostninger (www.vd.dk)
} 
Da det som sagt er usikkert, hvornår dødsfald som følge af dioxinindtaget kan risikere at indtræde, anvendes som hovedanslag 5,3 millioner danske kroner (dvs. værdien af et kronisk luftforureningsdødsfald), og der inkluderes et følsomhedsinterval på $+/-20 \%$, dvs. 4,24 til 6,36 mio. danske kroner.

Et af problemerne ved at anvende VSL-værdier fra andre undersøgelser er, at der ikke tages højde for usikkerheden ved dosis/respons-modellen. Denne er væsentlig for valget af beregningsprisen på kræfttilfælde, idet VSL bør afspejle personernes betalingsvillighed for at opnå ændringen i kræftrisikoen. Hvis denne ændring ikke kommer alle lige meget til gode - nogle er mere udsat for at få kræft end andre - vil alle givetvis ikke betale det samme. Principielt bør man derfor kende de personspecifikke risikoændringer og de hertil svarende personspecifikke betalingsvilligheder; men dette er selvsagt urealistisk. Den generelle "beregningspris på kræft" som vi her benytter, må derfor opfattes som en afspejling af summen af betalingsvillighederne for at opnå risikoændringen.

\subsection{Beregning af omkostningsskøn}

På baggrund af ovenstående afsnit er det herefter muligt at opstille en tabel med de variable, der skal inddrages i beregningen af omkostningsskønnet.

Tabel 9: Variable med betydning for beregningen af skadesomkostningerne

\begin{tabular}{|l|l|}
\hline Variabel & Skøn \\
\hline Gennemsnitligt dagligt indtag af dioxin fra føden & $\begin{array}{l}1,7 \text { picogram TEQ/kg. } \\
\text { kropsvægt }\end{array}$ \\
\hline Dioxinudledning fra affald & $15,7 \mathrm{~g} \mathrm{I-TEQ/år}$ \\
\hline Samlet nedfald af dioxin & $226,23 \mathrm{~g}$ TEQ/år \\
\hline Andel af dansk producerede varer & $86 \%$ \\
\hline $\begin{array}{l}\text { Andelen af danske emissioner, der ender på dansk terri- } \\
\text { torium }\end{array}$ & $100 \%$ \\
\hline $\begin{array}{l}\text { Kræftrisiko pr. år som følge af 1 picogram TEQ pr. kg. } \\
\text { kropsvægt pr. dag }\end{array}$ & 0,000013 \\
\hline Antal eksponerede & 5.300 .000 personer \\
\hline Værdi for et statistisk liv & 5.300 .000 DKK \\
\hline Ton affald forbrændt pr. år. & 2.900 .000 \\
\hline
\end{tabular}

Kilder: Se ovenstående gennemgang af variable

I det følgende udregnes de helbredsmæssige omkostninger ved dioxinudledningen pr. ton forbrændt affald på baggrund af de nævnte variable.

Danskernes årlige indtag af dioxin fra fødevarer svarer til: 
1,7 picogram/kg. kropsvægt/person/dag

Dette omregnes til den samlede indtagne mængde i Danmark om året:

1,7 picogram $/ \mathrm{kg}$. kropsvægt/person $/ \mathrm{dag} \cdot 62 \mathrm{~kg} \cdot \cdot 5,3$ mio. personer $\cdot 365$ dage

$=203.896 .300 .000$ picogram $($ eller $203,90 \mathrm{mg}){ }^{37}$

Heraf stammer ca. 86 pct. fra dansk producerede fødevarer,

dvs. $0,86 \cdot 203,90 \mathrm{mg}=175.350 .818 .000$ picogram $=175 \mathrm{mg}$

Dette betyder, at alle danskere tilsammen indtager $175 \mathrm{mg}$ dioxin gennem føden, der kan stamme fra danske fødevarer.

Tilførslen af dioxin til det fødevareproducerende areal (landbrugsareal og hav) udgjorde som nævnt 226,23 g dioxin. Heraf ender altså $175 \mathrm{mg}$ i dansk producerede fødevarer, der konsumeres i Danmark. Andelen af det dioxin, danskerne indtager, ud af det samlede tilførsel udgør dermed:

$(175,35: 1000) \mathrm{g} / 226,23 \mathrm{~g}=0,08 \%$

Kilderne til tilførslen på 226,23 g udgøres af affaldsforbrænding (15,7 g), andre danske emissioner (Z) og tilførsler fra udlandet (Y). Man har

$226,23 \mathrm{~g}=(15,7 \mathrm{~g}+\mathrm{Zg}) \cdot \mathrm{k}+\mathrm{Y} \mathrm{g}$

idet tilførslerne til danske arealer kan opgøres som en andel (k) af de samlede danske emissioner:

$(15,7 \mathrm{~g}+\mathrm{Z} \mathrm{g}) \cdot \mathrm{k}=?$

\footnotetext{
${ }^{37}$ Gennemsnitsvægten på $62 \mathrm{~kg}$. fremkommer ved at antage, at befolkningen består af 46,5\% mænd (70 kg), 46,5\% kvinder (60 kg) og 7\% børn (20 kg) (Holland et al. 1999:191).
} 
Da vi ikke har kendskab til størrelsen på k, sættes denne som nævnt til 1, dvs. vi antager, at hele den danske dioxinemission ender på dansk territorium.

Endvidere kan ændringerne i de samlede danske emissioner fra affaldsforbrænding $\mathrm{d}$ (affaldsemissioner) opgøres som

$\Delta($ affaldsemissioner $)=\Delta($ udledningskoefficient $) \cdot \Delta($ affaldsmængde $)$

Vi ved, at udledningskoefficienten i øjeblikket er $5,41 \cdot 10^{-6} \mathrm{~g}$ dioxin/ton. Heraf ses det, at forbrændes der et ton affald mindre pr. år, så reduceres dioxinemissionen med:

$5,41 \cdot 10^{-6} \mathrm{~g}$ dioxin/ton $\cdot 1$ ton/år $=5,41$ mikrogram.

Herefter kan ændringen i danskernes indtag af dioxin ved at ændre emissionerne fra affaldsforbrænding opgøres som

$\Delta($ dioxinindtag $)=\Delta($ affaldsemissioner $) \cdot \mathrm{k} \cdot 0,0775 \%$

Med $\mathrm{k}=1$ bliver ændringen i dioxinindtaget, når affaldsmængden ændres med 1 ton:

$\Delta$ (dioxinindtag) $\quad=5,41$ mikrogram dioxin $\cdot 1 \cdot 0,0775 \%$

$=0,0042$ mikrogram dioxin $=4196$ picogram dioxin

Herefter findes ændringen i picogram/kg. kropsvægt/dag pr. person:

$\Delta($ dioxinindtag $) \quad=4196$ picogram dioxin $/(62 \mathrm{~kg} \cdot 5.300 .000$ personer $\cdot 365$ dage $)$ $=3,5 \cdot 10^{-8} \mathrm{picogram}$ dioxin $/ \mathrm{kg}$. kropsvægt $/ \mathrm{dag}$

Med andre ord: Forbrændes der 1 ton affald mindre om året, reduceres danskernes indtag af dioxin med 3,5 $10^{-8}$ picogram dioxin $/ \mathrm{kg}$. kropsvægt $/ \mathrm{dag}$.

Dette tal skal herefter kobles med dosis/respons-modellen for at estimere, hvor mange færre dødelige kræfttilfælde der vil forekomme, hvis der blev forbrændt et ton affald mindre om året. Dosis/respons-modellen er opgjort til 0,001 risiko pr. picogram/kg. kropsvægt/dag hele livet. Som nævnt er dette et udtryk for, at fødes 1.000 personer på samme tid, vil én af dem i løbet af de næste 77 år (deres forventede levetid) få kræft og dø som følge af et dioxinindtag på 1 picogram $/ \mathrm{kg}$. kropsvægt/dag. For at dette skal resultere i ét kræfttilfælde om året, er man nødt til at antage en ligevægtsbefolkning på 77.000 perso- 
ner. Med en ligevægtsbefolkning på 5,3 mio. mennesker vil der derfor blive 68,8 kræfttilfælde om året.

$\mathrm{Nu}$ er der ikke tale om at indtage 1 picogram mindre pr. dag, men kun om at indtage 4 . $10^{-9}$ picogram mindre (som følge af, at der forbrændes et ton affald mindre). Derfor bliver der "kun" 68,8 kræfttilfælde pr. picogram dioxin $\cdot 3,5 \cdot 10^{-8}$ picogram dioxin $=2,4 \cdot 10^{-6}$ færre kræfttilfælde om året.

Herefter indsættes en pris pr. kræfttilfælde på 5,3 mio. DKK:

Årlig omkostning pr. ton affald $=5,3$ mio. DKK $/ \mathrm{kræfttilfælde} \cdot\left(2,4 \cdot 10^{-6} \mathrm{kræfttilfælde}\right)$ $=12,8 \mathrm{DKK}$.

Konklusionen på dette regneeksempel er således, at de til kræftdødsfald relaterede samfundsøkonomiske omkostninger ved at afbrænde et ton affald udgør ca. 12,8 DKK om året.

\subsection{Følsomhedsanalyse}

Da alle led i beregningen som nævnt er meget usikre, er det interessant at undersøge, på hvilken måde det endelige omkostningsestimat varierer, når værdierne for de enkelte variable ændres. Da vi kun i få tilfælde har en forestilling om den reelle usikkerhed ved det pågældende estimat, er det nødvendigt at lave en følsomhedsanalyse. Vi analyserer således kun effekten af udsving i data, men tager ikke stilling til, hvilken udsvingsstørrelse der evt. er sandsynlig. Dette giver et billede af, hvor robust resultatet er, samt hvilke faktorer der har den væsentligste betydning. Der opstilles to følsomhedsanalyser (se evt. Finansministeriet, 1999:84).

I den første analyse varieres værdien for hver enkelt variabel, mens de øvrige variable holdes konstant. Den variabel, der behandles, gives hhv. den højeste og laveste værdi, hvis der har været fremført et sikkerhedsinterval i de anvendte referencer. Hvis der ikke foreligger et officielt sikkerhedsinterval, er der anvendt et interval på $+/-20 \%$ (dette er markeret i tabellen). Undtaget fra denne regel er dosis/respons-modellen, der er varieret med $+/$ - faktor 10. Dette giver følgende variation i det endelige omkostningsestimat. 
Tabel 10: Følsomhedsanalyse af estimatet for de årlige helbredsomkostningerne ved forbrænding af 1 ton affald

\begin{tabular}{|l|l|l|l|}
\hline Variabel & $\begin{array}{l}\text { Centrale værdi } \\
\text { for variabel }\end{array}$ & Følsomhedsinterval & $\begin{array}{l}\text { Omkostning, } \\
\text { DKK/ton affald } \\
\text { pr. år }\end{array}$ \\
\hline Centralt skøn & 1,7 & $0,8-7,2$ & 12,8 \\
\hline $\begin{array}{l}\text { Gennemsnitligt dagligt ind- } \\
\text { tag af dioxin fra føden, pi- } \\
\text { cogram TEQ }\end{array}$ & 15,7 & $6,4-28,9$ & $6,0-54,1$ \\
\hline $\begin{array}{l}\text { Dioxinudledning fra affald, } \\
\text { g I-TEQ/år }\end{array}$ & 15 & $13-130$ & $5,2-23,5$ \\
\hline $\begin{array}{l}\text { Deposition på Danmarks } \\
\text { landareal, g TEQ/år }\end{array}$ & 75 & $69-100 * *$ & $10,2-14,8$ \\
\hline $\begin{array}{l}\text { Andel af dansk producerede } \\
\text { varer, \% }\end{array}$ & 86 & 90 & $11,5-13,7$ \\
\hline $\begin{array}{l}\text { Andelen af danske emissio- } \\
\text { ner, der ender på dansk terri- } \\
\text { torium, \% }\end{array}$ & 100 & $6.360 .000^{* *}$ & $10,1-15,3$ \\
\hline $\begin{array}{l}\text { Kræftrisiko pr. år som følge } \\
\text { af 1 picogram TEQ pr. kg. } \\
\text { kropsvægt pr. dag }\end{array}$ & 0,000013 & $0,00013-$ & $0,0000013^{* * *}$ \\
\hline $\begin{array}{l}\text { Antal eksponerede, perso- } \\
\text { ner }{ }^{38}\end{array}$ & 5.300 .000 & $*$ & $1,28-127,7$ \\
\hline $\begin{array}{l}\text { Værdi for et statistisk liv, } \\
\text { DKK }\end{array}$ & 5.300 .000 & $4.200 .000-$ & $*$ \\
\hline $\begin{array}{l}\text { Ton affald forbrændt pr. år., } \\
\text { antal }\end{array}$ & 2.900 .000 & $*$ & 1,7 \\
\hline
\end{tabular}

* Ingen mening at variere værdien.

$* *+/-20 \%$

$* * *+/-$ faktor 10

Ovenstående følsomhedsanalyse viser altså, at hvis henholdsvis højeste og laveste værdi for hver variabel indsættes i udregningen, spænder omkostningsintervallet fra $1-128$ DKK pr. ton affald.

\footnotetext{
${ }^{38}$ Pr. 1.1.2000 og 2001 var det danske indbyggertal hhv. 5,330 mio. og 5,349 mio. Her anvendes en værdi på 5,3 mio. mennesker.
} 
I den anden analyse opstilles et interval, der må antages at indkredse ekstremværdierne. Det foregår som følger: nederste værdi i intervallet udregnes således, at alle variable peger på så lav en værdi som muligt, mens højeste værdi i intervallet udregnes således, at alle variable peger på så høj en værdi som muligt. Hvor der i foregående interval kun blev varieret på én parameter ad gangen, varieres alle parametre således på een gang i denne analyse.

Tabel 11: Ekstreme værdier

\begin{tabular}{|l|l|l|l|}
\hline Variabel & $\begin{array}{l}\text { Central } \\
\text { værdi }\end{array}$ & $\begin{array}{l}\text { Lav } \\
\text { værdi }\end{array}$ & $\begin{array}{l}\text { Høj } \\
\text { værdi }\end{array}$ \\
\hline $\begin{array}{l}\text { Gennemsnitligt dagligt indtag af dioxin fra føden, pico- } \\
\text { gram TEQ }\end{array}$ & 1,7 & 0,8 & 7,2 \\
\hline Dioxinudledning fra affald, g/år & 15,7 & 6,4 & 28,9 \\
\hline Deposition på Danmarks landareal, g/år & 75 & 130 & 13 \\
\hline Andel af dansk producerede varer, \% & 86 & 69 & 100 \\
\hline $\begin{array}{l}\text { Andelen af danske emissioner, der ender på dansk terri- } \\
\text { torium, } \%\end{array}$ & 100 & 90 & 100 \\
\hline $\begin{array}{l}\text { Kræftrisiko pr. år som følge af 1 picogram TEQ pr. kg. } \\
\text { kropsvægt pr. dag }\end{array}$ & $\begin{array}{l}0,00001 \\
3\end{array}$ & 0,00000 & 0,00013 \\
\hline Antal eksponerede, mio. personer & 5,3 & $*$ & $*$ \\
\hline Værdi for et statistisk liv, mio. DKK & 5,30 & 4,24 & 6,36 \\
\hline Ton affald afbrændt pr. år., antal & $\begin{array}{l}2.900 .0 \\
00\end{array}$ & $*$ & $*$ \\
\hline Årlig omkostning pr . ton forbrændt affald, DKK. & 12,8 & 0,1 & $7.848,2$ \\
\hline
\end{tabular}

* varieres ikke

Som det fremgår af denne tabel, ligger de samfundsøkonomiske omkostninger ved dioxinudledningen fra et ton forbrændt affald imellem 10 øre og 7.848 DKK. Dette viser, at der hersker meget stor usikkerhed om et sådant skøn.

Begge tabeller giver et fingerpeg om, hvilke variables usikkerhed der har stor betydning for det endelige omkostningsestimat. Det fremgår f.eks., at usikkerheden ved dosis/respons-modellen får stor betydning for det endelige skøn. Til gengæld var det også det bredeste følsomhedsinterval, der blev inddraget for denne variabel pga. usikkerheden ved dosis/respons-sammenhængen.

Begge tabeller viser desuden, at selv små variationer i de valgte variable kan give udsving i det endelige omkostningsskøn. 
Ifølge ECON (2001:23) udgør omkostningerne ved dioxinerne på nuværende tidspunkt omtrent $7 \%$ af de beregnede skadesomkostninger ved forbrænding på i alt $324 \mathrm{NOK}$. Ved implementeringen af affaldsdirektivet formodes denne andel at falde til ca. 0,3\%. Med udgangspunkt i hovedskønnet på ca. 13 DKK kan denne konklusion ikke afvises for Danmarks vedkommende. Det må derfor med forsigtighed formodes, at dioxinerne sandsynligvis ikke giver anledning til en meget stor del af de samlede samfundsøkonomiske omkostninger ved affaldsforbrænding.

Spørgsmålet er, om dette skøn på ca. 13 DKK pr. ton forbrændt affald er udtryk for et nedre eller øvre skøn. Dette har betydning for i hvor høj grad, det må siges at stemme overens med forsigtighedsprincippet. Som nævnt kan man argumentere for, at et højt skøn - der tager højde for selv relativt usikre effekter - vil være mere i overensstemmelse med dette princip end et lavt skøn.

Flere aspekter peger på, at der er tale om et lavt skøn, dvs. at de reelle omkostninger ved affaldsforbrændingen sandsynligvis er højere. For det første er der ikke inkluderet omkostninger for de eventuelle miljømæssige skader, som dioxinerne kan forvolde. Da vi ikke har kendskab til, hvilke effekter dioxiner kan have på naturen, kan vi ikke afgøre, hvor væsentlig denne udeladelse er. For det andet er der ikke indregnet nogen omkostninger i forbindelse med dioxinernes morbiditetseffekter. På baggrund af de mange øvrige helbredseffekter, som dioxiner tilsyneladende giver anledning til, må dette betragtes som væsentligt. For det tredje har opgørelsen af det danske havareal stor betydning for det endelige skøn. Spørgsmålet er, om ikke en inddragelse af dansk landbrugsjord alene ville have været mere relevant, fordi der er så stor usikkerhed mht. spredningen af dioxin over vand, samt sammenhængen mellem denne dioxin og dioxinindholdet i danske spisefisk. Problemet er dog, at en eksklusion af havarealet ville have betydet en eksklusion af fisk fra indtaget af dioxin, hvilket ville have givet en alvorlig skævhed i beregningen.

Til gengæld er der også faktorer, der peger på, at de ca. 13 DKK er et højt skøn. Her er det vigtigste nok dosis/respons-modellen. Som det angives af den amerikanske miljøstyrelse udtrykker dosis/respons-modellen en "upper bound risk", dvs. der er mere end 95\% sandsynlighed for, at risikoen i virkeligheden er mindre (US-EPA, 2000/part III:97). Denne variabel må derfor bidrage til at trække omkostningsskønnet markant opad. Desuden er antagelsen om, at 100\% af de danske emissioner fra affaldsforbrændingen ender i Danmark, også med til at trække omkostningsskønnet højere op. Ifølge følsomhedsanalysen har dette dog tilsyneladende ikke den store betydning for det endelige estimat.

Da der således er væsentlige effekter, der taler for, at de reelle omkostninger er både højere og lavere, er det ikke muligt at vurdere, om skønnet på ca. 13 DKK lever op til forsigtighedsprincippet.

\subsubsection{Forskelle til de væsentligste referencer}

I nedenstående tabel 12 og 13 er anført skønnene for en række nyere analyser af eksternalitetsomkostningerne ved udledning af dioxin i forbindelse med affaldsforbrænding. 
Tabel 12: Omkostninger ved dioxin fra affaldsforbrænding

\begin{tabular}{|l|l|l|l|l|}
\hline Reference & $\begin{array}{l}\text { ECON, 1995 } \\
39\end{array}$ & CEC, 1996 & $\begin{array}{l}\text { Rabl, Spadaro } \\
\& \text { McGavran, } \\
1998^{41}\end{array}$ & ECON, 2001 \\
\hline $\begin{array}{l}\text { Emissionskoefficient } \\
\text { (TEQ mikrogram/ton } \\
\text { affald) }\end{array}$ & 14,7 & $\begin{array}{l}\text { max. 5 ng. I- } \\
\text { TEQ/Nm }\end{array}$ & $0,52^{* *}$ & 10 \\
\hline $\begin{array}{l}\text { Helbredsomkostninger } \\
\text { pr. gram dioxin pr. g } \\
\text { TEQ }\end{array}$ & 7,6 mio. NOK & $\begin{array}{l}50,5-257 \text { eu- } \\
\text { ro }\end{array}$ & 16.300 euro & 2,3 mio. NOK \\
\hline Værdi af statistisk liv & 35 mio. NOK & 2,6 mio. euro & 1,5 mio. euro ${ }^{43}$ & 12 mio. NOK \\
\hline $\begin{array}{l}\text { Helbredsomkostninger } \\
\text { pr. ton affald }\end{array}$ & 94 NOK & 0 euro & $<0,01$ euro & 23,80 NOK \\
\hline
\end{tabular}

Kilde ECON, 1995:32,37,105; CEC, 1996; Rabl, Spadaro og McGavran, 1998; ECON, 2001:23

* = omregningsfaktor på $6500 \mathrm{Nm}^{3}$ røggas/ton forbrændt affald. $\mathrm{Nm}^{3}$ betyder "normal kubikmeter". "Normal" refererer til standardtryk og temperatur - f.eks. 1013 mbar og 25 grader.

** = omregningsfaktor på $5150 \mathrm{Nm}^{3}$ røggas/ton forbrændt affald

\footnotetext{
${ }^{39}$ Vedrørende dosis/respons-model er det angivet, at "Ifølge Heijungs m.fl. (1992) er 1 gram dioksin til luft nok til å utsette 3,3 millioner mennesker for 1/10 000 risiko for kreft (eller annen, ekvivalent ulempe)..." (ECON, 95:74).

${ }^{40}$ Her regnes i I-TEQ i stedet for TEQ.

${ }^{41}$ Her anvendes en dosis/respons-model på 100 kræfttilfælde pr. mikrogram TEQ/kg kropsvægt/dag. Dette er lig $1 \cdot 10^{-4}$ kræfttilfælde pr. picogram TEQ/kg kropsvægt/dag. Det antages, at befolkningstætheden er 105 personer pr. km². Modellen stammer fra en tidligere analyse fra den amerikanske miljøstyrelse.

${ }^{42}$ Værdien afhænger af skorstenshøjden. Der er desuden angivet en række omkostningsestimater, når en dosis/responsmodel fra US-EPA anvendes. Disse er noget højere.

${ }^{43}$ Her regnes i værdi for et kræfttilfælde - både dødeligt og ikke-dødeligt. Desuden regnes i YOLL.
} 
Tabel 13: Omkostninger for dioxinudslip til luft ved forbrænding af forskellige affaldsfraktioner

\begin{tabular}{|c|c|c|c|}
\hline Affaldstype & $\begin{array}{l}\text { Hovedanslag } \\
(\mathrm{VSL}=12 \text { mio. } \\
\text { NOK) }\end{array}$ & $\begin{array}{l}\text { Højt anslag } \\
\text { (VSL = } 30 \text { mio. } \\
\text { NOK) }\end{array}$ & $\begin{array}{l}\text { Ny teknologi } \\
(\mathrm{VSL}=12 \text { mio. } \\
\text { NOK) }\end{array}$ \\
\hline \multicolumn{4}{|c|}{ NOK pr. ton affaldsfraktion } \\
\hline Papir/pap & 17 & 47 & ,5 \\
\hline Plast & 17 & 47 & ,5 \\
\hline Vådt organisk affald & 67 & 186 & 1 \\
\hline Metal & 0 & 0 & 0 \\
\hline Glas & 0 & 0 & 0 \\
\hline Træ & 17 & 47 &, 5 \\
\hline Tekstil & 48 & 134 & ,5 \\
\hline $\begin{array}{l}\text { Bl.a. husholdningsaf- } \\
\text { fald }\end{array}$ & 33 & 91 & ,5 \\
\hline
\end{tabular}

Kilde: ECON 2000:68-69 $9^{44}$, helbredsomkostningerne ved dioxin sættes til 2,3 mio. NOK pr. gram.

De to nyeste undersøgelser - ECON-analyserne fra Norge - anfører estimater på hhv. 24 NOK og 33 NOK pr. ton forbrændt affald, hvilket er ca. dobbelt så højt som estimatet fra nærværende undersøgelse på ca. 13 DKK. I det følgende diskuteres det, hvilke forskelle der bl.a. ligger bag disse forskellige omkostningsestimater. Forskellen analyseres via en gennemgang af de inkluderede variable.

For det første er der forskel på det årlige gennemsnitsindtag af dioxin fra fødevarer i de forskellige lande. Dette kan f.eks. skyldes forskelle i spisevaner, såsom andelen af fisk og kød i kosten.

For det andet kan der være forskel på, hvor stor en mængde dioxin, der indtages via hjemmeproducerede fødevarer. Dette afhænger af import- og eksportforholdene i det pågældende land.

For det tredje er der sandsynligvis forskel på den samlede årlige dioxinmængde, der tilføres det fødevareproducerende areal i det pågældende land. Dette afhænger bl.a. af landets og fødevareproduktionens størrelse i landet.

For det fjerde kan der være forskel på, hvor stor en del af emissionerne fra et bestemt land, der ender på det pågældende lands territorium. Dette afhænger bl.a. af vindforholdene.

\footnotetext{
${ }^{44}$ Denne værdi er fastsat ud fra Staring \& Vennemo (1997). Der er ikke angivet en dosis/respons-model.
} 
For det femte er der forskel på affaldsemissionskoefficienten, dvs. udledningen af dioxin pr. ton forbrændt affald. I Danmark er det gennemsnitlige udslip af dioxin til luften fra affaldsforbrænding som nævnt ca. 15,7 g I-TEQ. Det svarer til ca. 5,41 mikrogram pr. ton. Værker med filter formodes at have en emissionskoefficient på omkring 0,65 picogram/ton affald, hvilket lever op til kravene i det nye affaldsdirektiv. Forskellige systemer for forbrænding betyder, at denne værdi varierer fra land til land. Til sammenligning er udslippet i Sverige ca. 3 g, hvilket er ca. 1,58 picogram/ton affald (Ahlgren \& Marklund, 2002). I Norge opgøres dioxinudslippet pr. ton affald til 9,3 mikrogram dioxin (ECON, 2000:13).

For det sjette er der forskel på, hvilken dosis/respons-funktion der er anvendt i de forskellige analyser. Som nævnt anvendes i nærværende analyse en risiko på $1 \cdot 10^{-3}$ risiko/picogram TEQ/kg. kropsvægt pr. dag (US-EPA, 2000/part III:97). Med en gennemsnitslevealder på 77 år svarer dette til, at 13 ud af 1.000.000 dør om året som følge af 1 picogram TEG/kg kropsvægt pr. dag. Den tidligste ECON-rapport fra 1995 angiver følgende dosis/respons-model: "Ifølge Heijungs m.fl. (1992) er 1 gram dioksin til luft nok til å utsette 3,3 millioner mennesker for 1/10 000 risiko for kreft (eller annen, ekvivalent ulempe)..." (ECON, 1995:74). Rabl, Spadaro og McGavran (1998:25) opstiller en lineær sammenhæng mellem dioxinindtag og antallet af kræfttilfælde og finder en hældningskoefficient på 100 kræfttilfælde (både dødelige og ikke-dødelige) pr. mikrogram TEQ/kropsvægt pr. dag. Dette svarer til $1 \cdot 10^{-4}$ kræfttilfælde pr. picogram TEQ pr. kg. kropsvægt pr. dag (da 1 picogram er lig $1 \cdot 10^{-6}$ mikrogram). Kræftrisikoen i nærværende undersøgelse antages dermed at være 10 gange højere.

Den dosis/respons-model fra US-EPA, der anvendes i nærværende undersøgelse, repræsenterer imidlertid den nyeste forskning på området. Det må dog understreges, at dosis/respons-modellen som nævnt udtrykker en "upper bound risk", dvs. der er mere end 95\% sandsynlighed for, at risikoen i virkeligheden er mindre (US-EPA, 2000/part III:97). Til gengæld er morbiditetseffekterne ikke er indregnet, hvilket - i kraft af de tilsyneladende mange dioxinrelaterede lidelser - må betragtes som en væsentlig udeladelse. I denne sammenhæng har det også betydning, om undersøgelserne opererer med en tærskelværdi for helbredseffekter. I den europæiske evaluering af affaldsdirektivet (CEC, 1996:6-1) anerkendes det, at dioxin er yderst sundhedsskadeligt, og der fastsættes en helbredsomkostning pr. gram udledt dioxin. Da man imidlertid opererer med en tærskelværdi for, hvornår helbredseffekterne indtræder, og man samtidig regner med en dioxinudledning under dette niveau, sættes de helbredsmæssige omkostninger til $0 .{ }^{45}$

Endelig er der forskel på, hvilken værdi de enkelte undersøgelser har tillagt et statistisk liv. I denne undersøgelse har vi valgt værdien 5,3 mio. DKK for et statistisk liv, hvor de to nyeste ECON-undersøgelser f.eks. har valgt værdierne 12 og 35 millioner NOK. De andre nævnte referencer har anvendt værdier på 1,5 mio. euro og 2,6 mio. euro, hvilket svarer til ca. 11,25 mio. DKK og 19,5 mio. DKK. Dette har naturligvis også stor betydning for det endelige estimat.

\footnotetext{
${ }^{45}$ Der laves desuden beregninger under antagelse af, at der ikke findes en tærskelværdi. Her anvendes bl.a. en dosis/respons-model fra det tyske LAI (Länderausschuss für Immissionsschutz, 1992).
} 
Samlet set betyder disse mange forhold derfor, at omkostningerne ved helbredseffekter, der forårsages af dioxinudledning fra affaldsforbrænding, må forventes at variere fra land til land, hvorfor det til dels ikke er overraskende, at de hidtidige undersøgelser fra f.eks. ECON er nået frem til resultater, der afviger fra nærværende analyse. Samtidig er resultaterne dog ikke mere forskellige, end at de understreger nærværende analyses konklusion om, at selvom dioxinerne potentielt set udgør en stor fare for det menneskelige helbred, så udledes der så begrænsede mængder fra affaldsforbrændingen, at de samfundsøkonomiske omkostninger, der er forbundet med stofferne, kun udgør en begrænset del af de samlede omkostninger. 


\section{$\underline{5 . ~ K o n k l u s i o n e r}$}

I den første del af dette projekt blev det nordiske og internationale vidensgrundlag om prissætning af miljø- og sundhedseffekterne ved affaldsbehandling opgjort med henblik på at vurdere niveauet for slutbehandlingsafgifterne på affald i de nordiske lande (Dengsøe, 2001). Formålet med denne rapport har været at udbygge den eksisterende viden vedrørende prissætning af de eksterne effekter af lavdosisemissioner fra affaldsforbrænding. Dette blev indsnævret til en analyse af de samfundsøkonomiske omkostninger ved dioxinudledningen i forbindelse med affaldsforbrænding.

Der blev foretaget et omfattende litteraturstudie af dioxiner og disses effekter på det menneskelige helbred og miljøet. Det blev konstateret, at der på nuværende tidspunkt er udpeget en lang række helbredseffekter, der kan relateres til dioxineksponering. Til gengæld vurderes miljøeffekterne af dioxin at være begrænsede.

Selvom der er identificeret en række skadelige effekter på det menneskelige helbred, er mange af disse effekter endnu usikre, og der findes stort set ingen dosis/respons-modeller, der kvantificerer sammenhængen mellem dioxineksponeringen og helbredsskaderne. Derfor har vi måttet udelade morbiditetseffekterne fra prissætningen. En stor, ny, amerikansk undersøgelse har imidlertid forsøgt at opstille en dosis/respons-model for sammenhængen mellem det daglige indtag af dioxin og risikoen for at dø af kræft. På baggrund af denne model samt danske data vedrørende dioxinudledning fra affaldsforbrænding og indtag via maden har det herefter været muligt at opstille en forsøgsvis beregning af de samfundsøkonomiske omkostninger ved dioxinudledning fra affaldsforbrænding i Danmark.

Resultatet af denne beregning var, at det bedste skøn for de til kræftdødsfald relaterede skadesomkostninger, som dioxinudledningen må formodes at give anledning, ligger på omtrent 13 DKK pr. ton affald. Et af de væsentlige formål med denne rapport har bl.a. også været at opstille en metode til at følge en emissionstype fra udledningsdata til de samfundsøkonomiske omkostninger ved emissionernes effekter. Dette viste sig at være relativt kompliceret og at indebære en lang række antagelser vedrørende data, som det ikke var muligt at skaffe samt en lang række usikkerheder i forbindelse med de data, det var muligt at skaffe. Følsomhedsanalysen viste således, at det endelige estimat kan variere mellem 1 og 128 DKK pr. ton affald pga. usikkerhederne ved de variable, der inkluderes i beregningen. Foretages i stedet en beregning, hvor alle variable peger i en bestemt retning, kan skønnet endog variere mellem 10 øre og 7.848 DKK pr. ton affald. Det er ikke muligt at afgøre, om 13 DKK pr. ton affald er udtryk for et nedre eller øvre skøn for omkostningerne ved de samlede helbredseffekter ved dioxin fra affaldsforbrænding.

En væsentlig konklusion ved undersøgelsen er derfor dels, at omkostningsestimater som disse - der f.eks. anvendes i cost/benefit-analyser - altid skal ses i sammenhæng med de antagelser, der er gjort vedrørende inkluderede variable. Dels må det konkluderes, at disse estimater er meget usikre, idet både udledningsdata, eksponeringsdata og ikke mindst do- 
sis/respons-modellerne er yderst usikre. Dette er en væsentlig pointe, når man ønsker at anvende estimaterne $\mathrm{i}$ den politiske beslutningsproces.

Det mest sandsynlige estimat for omkostningerne ved dioxinudledningen formodes dog at være omtrent 13 DKK pr. ton forbrændt affald. Tidligere undersøgelser, såsom ECON (2001:23) finder, at de samlede samfundsøkonomiske omkostninger ved affaldsforbrænding ligger på omkring 324 NOK ved de nuværende norske regler og 619 NOK, når det nye affaldsdirektiv implementeres i norsk lovgivning. ${ }^{46}$ Såfremt de danske og norske omkostninger ved forbrænding af et ton affald er sammenlignelige, vil omkostningerne ved dioxinudledning udgøre en relativt begrænset del af de samlede samfundsøkonomiske omkostninger, der er forbundet med forbrændingen af affald. Dette er illustreret i tabel 14, hvor de dioxinudledningskoefficienter, skades-omkostninger pr. ton affald og slutbehandlingsafgifter for de nordiske lande, som vi har kendskab til, er opført. Det har ikke været muligt at finde data vedrørende Island og Finland.

Tabel 14: Sammenligning mellem de nordiske lande

\begin{tabular}{|c|c|c|c|c|}
\hline Land & $\begin{array}{l}\text { Dioxinudledning } \\
\text { ved affalds- } \\
\text { forbrænding }\end{array}$ & $\begin{array}{l}\text { Dioxinomkost- } \\
\text { ning }\end{array}$ & $\begin{array}{l}\text { Samlede skades- } \\
\text { omkostninger }\end{array}$ & $\begin{array}{l}\text { Slutbehandlings- } \\
\text { afgift i } 2001\end{array}$ \\
\hline & $\begin{array}{l}\text { mikrogram/ton } \\
\text { affald }\end{array}$ & $\begin{array}{l}\text { euro pr. ton af- } \\
\text { fald }\end{array}$ & $\begin{array}{l}\text { euro pr. ton af- } \\
\text { fald }\end{array}$ & $\begin{array}{l}\text { euro pr. ton af- } \\
\text { fald* }\end{array}$ \\
\hline Danmark & $\begin{array}{l}\text { ca. } 5,41 \\
(0,65)^{47}\end{array}$ & 1,7 (12,8 DKK.) & & 44 \\
\hline Norge & ca. 9,30 & 3 (24 NOK.) & 40,5 (324 NOK) & $\begin{array}{l}10 \text { (grundafgift) } \\
0-29 \text { (tillægsaf- } \\
\text { gift) }\end{array}$ \\
\hline Sverige & ca. $1,58^{48}$ & & & \\
\hline $\begin{array}{l}\text { Nyt EU- } \\
\text { direktiv }\end{array}$ & ca. 0,65 & & & \\
\hline
\end{tabular}

Kilde: COWI, 2000; ECON, 2000:13; Ahlgren \& Marklund, 2002:3,6; Dengsøe, 2001:9

* Omregningskurser: 1 euro $=7,5 \mathrm{DKK}=8 \mathrm{NOK}=9,25$ SEK (Dengsøe, 2001)

Af tabellen ses det, at samfundsomkostningerne ved dioxinudledningen sandsynligvis udgør en endnu mindre del af de samlede omkostninger i Danmark end i Norge. Nærværen-

\footnotetext{
${ }^{46}$ At afgiften sættes til et højere niveau efter implementeringen af affaldsdirektivet skyldes, at en række norske anlæg i 1999 udledte mindre krom m.v., end det er tilladt ifølge direktivet.

${ }^{47}$ Der er oplyst, at der udledes 15,7 g pr. år ved forbrænding af 2,9 mio. tons affald. Dette bliver 5,41 mikrogram/ton. Til gengæld fremfører repræsentanter for affaldssektoren, at der efter rensning udledes ca. 0,1 nanogram $/ \mathrm{Nm}^{3}$, hvilket svarer til ca. 0,65 mikrogram dioxin pr. ton affald.

${ }^{48}$ Der udledtes 3 g i 1999 ved forbrænding af 1,9 mio. tons affald (Ahlgren \& Marklund, 2002:3,6).
} 
de undersøgelse viser dog også, dioxin generelt udgør en stor sundhedsrisiko for mennesker. Det er derfor vigtigt at holde udledningen på de nuværende og fremtidige lave niveauer. På baggrund af nærværende analyse af dioxinrelaterede skadesomkostninger er der imidlertid ikke belæg for et forslag om at ændre slutbehandlingsafgiften på forbrænding i Danmark.

Som det fremgik af ECON-undersøgelserne, der blev refereret i tabel 3 (kap.2), er kemikalier såsom mangan og krom til gengæld bidragsydere til noget større andele af de samlede omkostninger ved forbrænding af affald. Ligesom det er tilfældet for dioxin, er de miljø- og helbredsmæssige effekter af disse kemikalier endnu ikke undersøgt tilstrækkeligt grundigt.

Resultaterne af dette projekt vil indgå i et dansk ph.d.-projekt om de samfundsøkonomiske omkostninger ved affaldsbehandling. Et af formålene med det projekt er at foretage en grundig undersøgelse af de samfundsøkonomiske omkostninger ved ovennævnte stoffer. 


\section{$\underline{\text { Referencer }}$}

Ahlgren, N. \& S. Marklund (2002), “Förbränning af avfall. En kunskapssammanställning om dioxiner", RVF Rapport 01:13, Sverige

Alexandersen, S.R., Kort- og Matrikelstyrelsen. Elektronisk kontakt vedrørende arealopgørelser, januar 2003.

Andersen, M. S. (2000), "Forsigtighedsprincippet - og dets rødder i det tyske Vorsorgeprinzip", Samfundsøkonomen nr. 1

Andersen, M.S. (2003), Danmarks Miljøundersøgelser, mailkontakt

Bertazzi, P.A., Dario Consonni, Silvia Bachetti, Maurizia Rubagotti, Andrea Baccarelli, Carlo Zocchetti \& Angela Pesatori (2001), "Health effects of Dioxin Exposure: A 20 years Mortality Study", American Journal of Epidemiology, Oxford University Press

Cederberg, T., J. C. Larsen \& L. Ovesen, "Indhold af dioxiner og dioxinlignende PCB i fisk og sundhedsmæssig vurdering i forhold til de kostråd Fødevaredirektoratet giver den danske befolkning", Fødevaredirektoratet, 1999, http://www.vfd.dk/diverse/dioxin_1/dioxin_b1.htm

Commission of the European Communities \& UK Department of the Environment Transport and the Regions (CEC \& DETR) (1999),"Compilation of EU Dioxin Exposure and Health Data", report by Dr. Deborah Buckley-Golder, Oxfordshire

Commission of the European Communities, CEC (1996), "Economic Evaluation of the Draft Incineration Directive"

Commission of the European Communities, CEC (1997),'European Dioxin Inventory Volume 1, Part A, General Aspects", http://europa.eu.int/comm/environment/dioxin/stage1/parta_intro.pdf

Commission of the European Communities, CEC (2000),"A Study on the Economic Valuation of Environmental Externalities from Landfill Disposal and Incineration of Waste", COWI Consulting Engineers and Planners AS

COWI (2000), " Substance Flow Analysis for dioxins in Denmark", Miljøprojekt nr. 570, København: Miljøstyrelsen

COWI (2003), " Substance Flow Analysis for Dioxin 2002". Udarbejdet af Erik Hansen og Charlotte Libak Hansen, Miljøprojekt nr. 811, København: Miljøstyrelsen

Danmarks Statistik (2002), 'Landbrug 2001 - Statistik om landbrug, gartneri og skovbrug", København: Danmarks Statistik

Dengsøe, N. (2001), "Vurdering af de nordiske slutbehandlingsafgifter på affald - økonomisk værdisætning og evaluering”, notat til Nordisk Ministerråd 
Dengsøe, N. (2002), "Gevinster ved genanvendelse - et litteraturstudie af internationale undersøgelser af de samfundsøkonomiske effekter ved genanvendelse af affald" arbejdsrapport fra Miljøstyrelsen

ECON, Senter for økonomisk analyse (1995), "Verdsetting av eksterne virkninger ved avfallsbehandling”, ECON-rapport 301/95

ECON, Senter for økonomisk analyse (1997), ’Miljøkostnader ved plastavfall”, ECONrapport nr. 31/97

ECON, Senter for økonomisk analyse (2000), "Miljøkostnader ved avfallsbehandling", ECON-rapport 85/00

ECON, Senter for økonomisk analyse (2001), "Utslippsavgift på forbrenning av avfall”, ECON-rapport 28/01

Elliott, P., G. Shaddick, I. Kleinschmidt, D. Jolley, P. Walls, J. Beresford \& C. Grundy (1996), "Cancer incidence near municipal solid waste incinerators in Great Britain", British Journal of Cancer, nr. 73

Fiedler, H., O. Hutzinger, K. Welsch-Pausch \& A. Schmiedinger (2000), 'Evaluation of the Occurrence of PCDD/PCDF and POPs in Wastes and Their Potential to Enter the Foodchain", University of Bayreuth, på vegne af Europakommissionen, DG Environment Finansministeriet (1999), "Vejledning i udarbejdelse af samfundsøkonomiske konsekvensvurderinger"

Fischer, C. \& M. Crowe (2000), "Household and municipal waste: Comparability of data in EEA member countries", København: European Environmental Agency (EEA)

Fødevaredirektoratet \& Plantedirektoratet (2001), "Rapport over DIOXINHANDLINGSPLAN 2000", København, http://www.vfd.dk/diverse/dioxin_1/dioxin.doc

Gravgaard, Ole, Danmarks Statistik, Nationalregnskabet, Sektion for Miljøregnskaber. Mail-kontakt d.8.11.2002

Hansen, Charlotte Libak, COWI, elektronisk mailkontakt vedrørende udledningsopgørelser, januar 2003

Hansen, Jørn L., Miljøstyrelsen. Mail den 6.december 2002

Holland, M., J. Berry \& D. Forster (1999), "Externe Externalities of Energy - vol.7: Methodology 1998 Update", European Commission, DG XII

Holland, M. \& P. Watkiss (2002), "BeTa - Version E1.02a. Estimates of the marginal external costs of air pollution", for European Commission DG Environment by NETCEN International Agency for Research on Cancer (IARC 1997), "Polychlorinated dibenzopara-dioxins and polychlorinated dibenzofurans". IARC monographs on the evaluation of carcinogenic risks to humans", vol. 69, Lyon

Institute for Environment and Health, IEH (1997), "Health effects of waste combustion products", report R7, Leicester: Institute for Environment and Health 
Kostnadsberegningsutvalget (1998), "Nytte-kostnadsanalyser. Veiledning i bruk av lønnsomhetsvurderinger i offentlig sektor", Norges Offentlige Utredninger (NOU) 1998:16

Larsen, John Christian, Fødevaredirektoratet. Samtale d.16. juli 2003

Länderausschuss für Immissionsschutz (LAI), (1992) "Krebsrisiko durch Luftverunreinigungen", Tyskland

Miljøstyrelsen (1997), " Dioxins", arbejdsrapport nr. 50, København

Miljøstyrelsen (2001), "Affaldsstatistik 2000", Orientering fra Miljøstyrelsen, nr. 14, www.mst.dk

Møller, F., S.P. Andersen, P. Grau, H. Huusom, T. Madsen, J. Nielsen \& L. Strandmark (2000), "Samfundsøkonomisk vurdering af miljøprojekter", Danmarks Miljøundersøgelser, Miljøstyrelsen og Skov- og Naturstyrelsen

Pearce, D. og A. Howarth (2000), "Technical Report on Methodology: Cost Benefit Analysis and Policy Responses" (RIVM report 481505020), http://www.rivm.nl/bibliotheek/rapporten/481505020.pdf

Poulstrup, A. \& H.L. Hansen (2003), "Cancer development due to airborne dioxin in a urban population assessed by use of exposure simulation models and GIS-based health registers", præsentationspapir til EUROHEIS/SAHSU konference 30./31. marts 2003 samt mailkontakt vedrørende denne undersøgelse

Rabl, A., J.V. Spadaro \& P.D. McGavran (1998), "Health Risks of Air Pollution from Incinerators: a Perspective", Waste Management \& Research Waste, vol.16

Rodan, B. (2002). Korrespondance via mail

Starring \& H. Vennemo (1997), "Pricing hazardous substance emissions", ECON-rapport 63/97, Oslo

Statens Forurensningstilsyn (SFT) (1996), "Utslipp ved håndtering av kommunalt avfall”, TA-1366/1996, Oslo: SFT

Statens Forurensningstilsyn (SFT) (2000), "Helseeffekter og samfunnsøkonomiske kostnader av luftforurensning. Luftforurensninger - effekter og verdier (LEVE)", TA1718/2000, Oslo: Statens Forurensningstilsyn

Steenland, K., J. Deddens \& L. Piacitelli (2001), "Risk Assessment for 2,3,7,8Tetrachlorodibenzo-p-Dioxin (TCDD) based on an Epidemiologic Study", American Journal of Epidemiology, Oxford University Press

Sundhedsnyt (2001): http://www.info.sum.dk/sundhedsnyt/2001/19/200119.htm)

US-EPA (2000), "Exposure and human health Reassessment of 2,3,7,8-

Tetrachloriddibenzo-p-Dioxin (TDCC) and Related Compounds", United States Environmental Protection Agency, Washington, http://cfpub.epa.gov/ncea/cfm/dioxreass.cfm

Vennemo, H. (1995), “Miljøkostnader knyttet til ulike typer avfall”, rapport 338/95

Vikelsøe, J. (2002a), ’Dioxin måleprogram - Statusrapport april 2002”, Roskilde: Danmarks Miljøundersøgelser 
Vikelsøe, Jørgen (2002b), Danmarks Miljøundersøgelser. Elektronisk mailkontakt november 2002

Vikelsøe, J. (2003), ’Dioxin Måleprogram. Statusrapport april 2003”, Danmarks Miljøundersøgelser

WHO (1999), "Health costs due to Road Traffic-related Air Pollution", udarbejdet til den ministerielle WHO-konference om Miljø og Sundhed i London, juni 1999

World Health Organization (WHO 1999), "Assessment of the health risk of dioxins: Reevaluation of the Tolerable Daily Intake (TDI)", WHO Consultation 25.-29. maj 1998, Geneve, Schweiz: WHO European Centre for Environmental Health and International Programme on Chemical Safety 
Nordisk Ministerråds og Nordisk Råds publikationer kan bestilles hos:

\section{BELGIEN \& LUXEMBOURG}

Jean de Lannoy

Avenue du Roi, 202, 1190 Brussels

$\mathrm{Tel}+32$ (0)2 $5385169 \mathrm{Fax}+32$ (0)25380841

jean.de.lannoy@euronet.be

\section{CANADA}

Renouf Publishing Company Ltd

5369 Canotek Road, Ottawa, Ontario K1J 9J3

Tel + 1 (613) $7452665 \mathrm{Fax}+1$ (613) 7457660

order.dept@renoufbooks.com

www.renoufbooks.com

\section{DANMARK}

Svensk-Norsk Bogimport A/S

Esplanaden 8 B, 1263 København $\mathrm{K}$

Tel +4533142666 Fax +4533143588

snb@bog.dk

www.snbog.dk

\section{ESTLAND}

Astro Raamatud AS

Pärnu mnt 142, 11317 Tallinn

Tel +372 6548485 Fax +372 6548475

book@astro.ee

\section{FINLAND}

Akademiska Bokhandeln

PB 128, Centralgatan 1, 00101 Helsingfors

Tel +358 912141

akatilaus@akateeminen.com

www.akateeminen.com

\section{FRANKRIG}

Librairie LAVOISIER

14, rue de Provigny, 94236 Cachan Cedex Tel +33 (1) $47406700 \mathrm{Fax}+33$ (1) 47406702 group@lavoisier.fr

www.lavoisier.fr

\section{FAERØERNE}

H.N. Jacobsens Bókahandil

Postboks 55, 110 Tórshavn

Tel +29831 $1036 \mathrm{Fax}+298317873$

hnj@hnj.fo

\section{HOLLAND}

De Lindeboom Internationale Publicaties b.v. M.A. de Ruyterstraat 20 A, NL-7482 BZ Haaksbergen Tel +31 (0)53 $5740004 \mathrm{Fax}+31$ (0)535729296 books@delindeboom.com

www.delindeboom.com

\section{ISLAND}

Mál og Menning

Laugavegi 18, 101 Reykjavik

Tel +354 (9)5152500 Fax +354 (9)5152505

verslun@mm.is

\section{KINA}

CNPIEC

Europe Division 16 Gongti East Road

P.O. Box 88, Beijing

Tel +86105066 688-8 Fax +86105063101

\section{LETLAND}

Jana Rozes Gramàtnica

Kr. Barona iela 5, 1011 Riga

Tel +371 (0)2 284288 Fax +371 7370922

\section{LITAUEN}

Penki Kontinentai

A. Stulginskio 5, 2001 Vilnius

Tel +370 (5) 2664540 Fax +370 (5) 2664565

books@5ci.lt

www.books.lt

NORGE

Akademika A/S

Postboks 84 Blindern, 0314 Oslo

Tel +4722853030 Fax +4722853080

bloken@sio.uio.no

www.akademika.no

\section{RUMAENIEN}

Euromedia s.r.I.

Str Dionisie Lupu nr 65, 70184 Bucuresti

Tel + 4016140664 Fax + 4013129646

\section{STORBRITANNIEN}

The Stationery Office

P.O. Box 276, London SW8 5DT

Tel +44 8706005522 Fax +44 8706005533

customer.services@tso.co.uk

www.tso.co.uk/bookshop

\section{SVERIGE}

Fritzes

Kundservice, 10647 Stockholm

Tel +46 (0)8 6909190 Fax +46 (0)8 6909191

order.fritzes@nj.se

www.fritzes.se

\section{TYSKLAND}

UNO-Verlag GmbH

Am Hofgarten 10, 53113 Bonn

Tel +49 (0)228949020 Fax +49 (0)2289490222

info@uno-verlag.de

www.uno-verlag.de

\section{UNGARN}

Euro Info Service

PO Box 1039, 1245 Budapest

Tel +36 (1) 3292487 Fax +36 (1) 3492053

euroinfo@euroinfo.hu

\section{USA}

Bernan

4611-F Assembly Drive, Lanham MD 20706-4391

Tel +1 (301) 4597666 Fax +1 (301) 4590056

query@bernan.com

www.bernan.com

\section{ÅLAND}

Lisco bok- och pappershandel

Skarpansvägen 25, Box 8, 22101 Mariehamn

Tel +358 (0)18 $17177 \mathrm{Fax}+358$ (0)18 19771 info@lisco.fi 